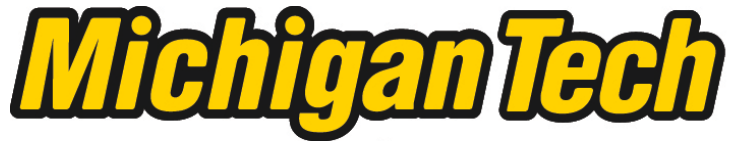 \\ Michigan Technological University Create the Future Digital Commons @ Michigan Tech
}

Dissertations, Master's Theses and Master's Reports - Open

Dissertations, Master's Theses and Master's

Reports

2014

\section{From Mill Gates to Magic City: U.S. Steel and Welfare Capitalism in Gary, Indiana, 1906-1930}

Carol D. Griskavich

Michigan Technological University

Follow this and additional works at: https://digitalcommons.mtu.edu/etds

Part of the History of Art, Architecture, and Archaeology Commons, Labor Relations Commons, and the Social and Cultural Anthropology Commons

Copyright 2014 Carol D. Griskavich

\section{Recommended Citation}

Griskavich, Carol D., "From Mill Gates to Magic City: U.S. Steel and Welfare Capitalism in Gary, Indiana, 1906-1930", Master's Thesis, Michigan Technological University, 2014.

https://doi.org/10.37099/mtu.dc.etds/842

Follow this and additional works at: https://digitalcommons.mtu.edu/etds

Part of the History of Art, Architecture, and Archaeology Commons, Labor Relations Commons, and the Social and Cultural Anthropology Commons 
FROM MILL GATES TO MAGIC CITY: U.S. STEEL AND WELFARE CAPITALISM IN GARY, INDIANA, 1906-1930

\author{
By \\ Carol D. Griskavich
}

\begin{abstract}
A THESIS
Submitted in partial fulfillment of the requirements for the degree of MASTER OF SCIENCE

In Industrial Archaeology
\end{abstract}

MICHIGAN TECHNOLOGICAL UNIVERSITY

2014

(C) 2014 Carol D. Griskavich 

This thesis has been approved in partial fulfillment of the requirements for the Degree of MASTER OF SCIENCE in Industrial Archaeology.

Department of Social Sciences

Thesis Advisor: Dr. Steven A. Walton

Committee Member: Dr. Carol A. MacLennan

Committee Member: Dr. Bradley H. Baltensperger

Department Chair: Dr. Patrick E. Martin 

For the people of Gary-past, present, and future. 



\section{Table of Contents}

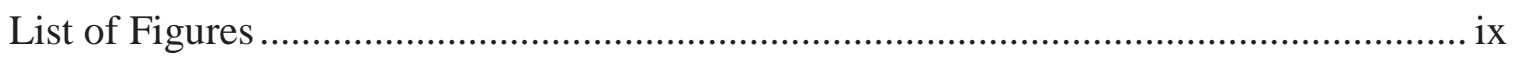

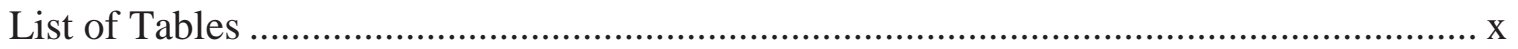

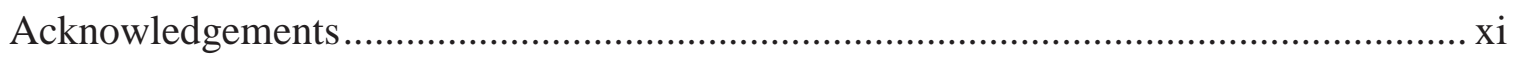

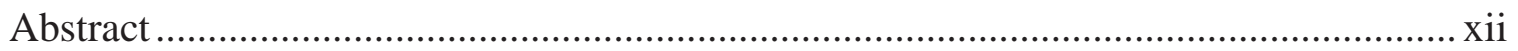

Chapter 1 : Tapping the First Heat of a New Paternalism ............................................... 1

Industrial Paternalism and Welfare Capitalism in Company Towns .............................. 2

Previous Research and Literature............................................................................. 3

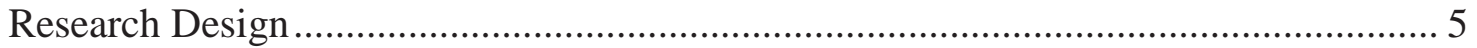

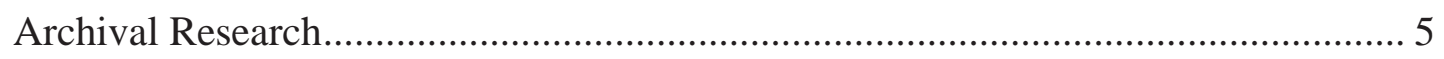

Ethnographic Fieldwork ................................................................................ 6

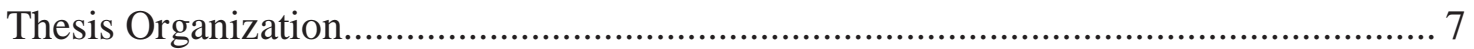

Introducing the "Steel City" to the Calumet Region................................................... 8

Chapter 2 : Housing a "City by Fiat"........................................................................... 15

Learning from Mistakes, Planning from Successes ...................................................... 16

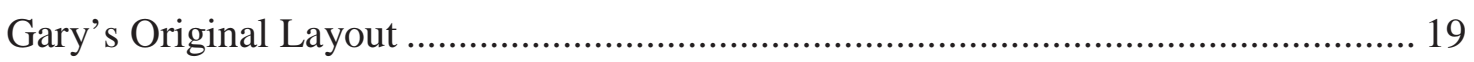

Gary Land Company's First Subdivision................................................................ 21

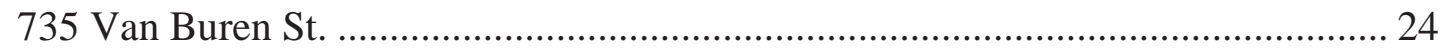

Polk Street Terraces - 402-422 Polk Street ………………………………………... 26

The "Steel Mill Quarter": Gary Land Company's Ninth Subdivision ........................... 33

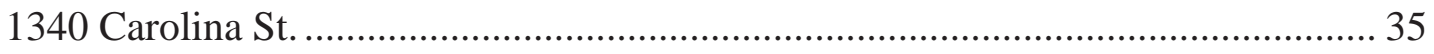

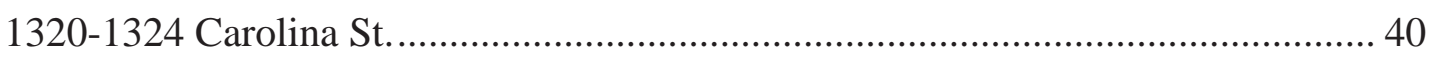

Chapter 3 : Education for All, Education for Life ......................................................... 55

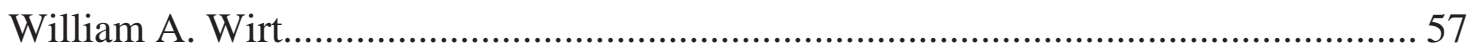

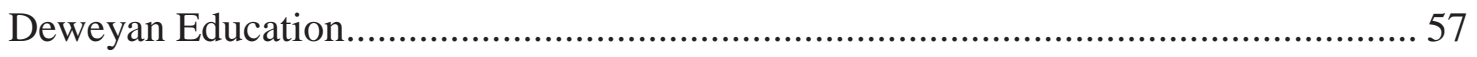

Arts and Crafts Movement Influence ......................................................................... 59

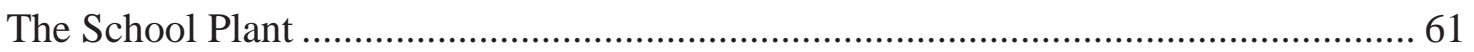

Equal Time and Equal Importance for Work, Study, and Play .................................... 62

Schools as Community Centers, Adult Education, and Americanization...................... 66 
Implementation Outside Gary Meets Criticism …………...................................... 70

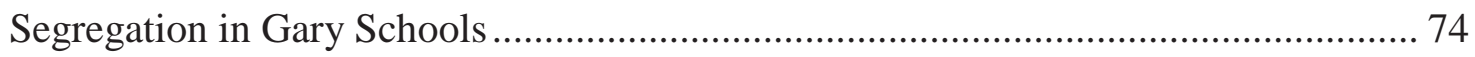

Chapter 4 : Welfare Capitalism as Social Capital.......................................................... 87

“Good Welfare Work, Like Good Business, Pays" ........................................................ 88

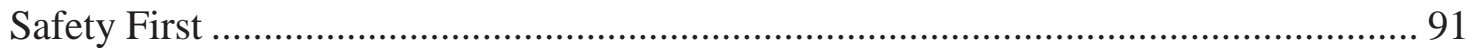

U.S. Steel Safety, Sanitation, and Welfare............................................................... 94

Time Well Spent While Not at Work ............................................................................... 96

Cultivating Healthy Americans .................................................................................. 97

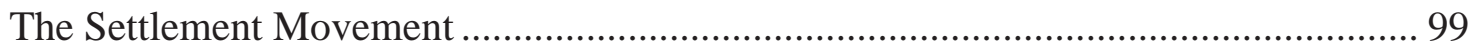

Serving a Catholic Majority .......................................................................................... 101

Segregated Social Welfare .................................................................................. 105

Chapter 5 : Perception, Place, and Pride in a Paternalistic Model City........................... 119

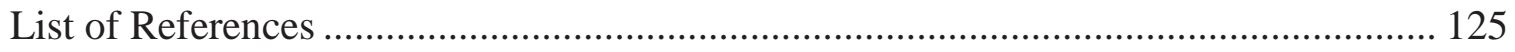

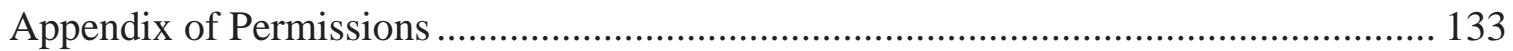




\section{List of Figures}

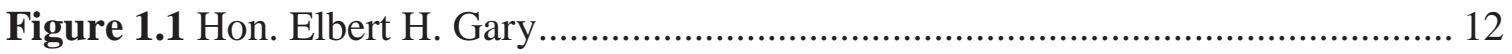

Figure 1.2 Map of Gary, Indiana, and the Calumet Region............................................ 13

Figure 2.1 Map of Gary Land Company's First and Ninth Subdivisions........................ 44

Figure 2.2 735 Van Buren Street ……………………...................................... 45

Figure 2.3 Edison Concept Concrete Homes, 600 blk. Polk Street, 1912 ....................... 46

Figure 2.4 Map of Edison Concept Concrete Homes ................................................... 47

Figure 2.5 Polk Street Terraces, 400-422 Polk Street, 2013 ........................................ 48

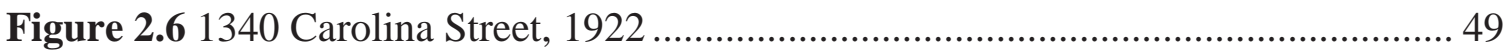

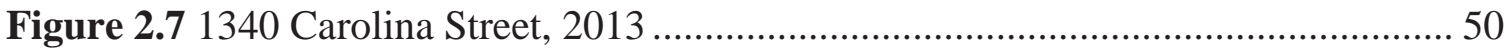

Figure 2.8 “John H. Smith (Colored), Janitor, Gary, Indiana," 1922 ............................. 51

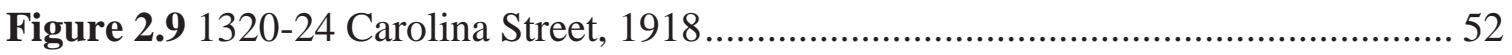

Figure 2.10 Map of Gary Land Company's Ninth Subdivision....................................... 53

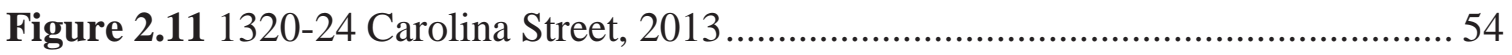

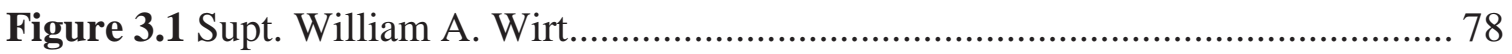

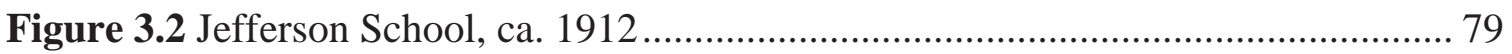

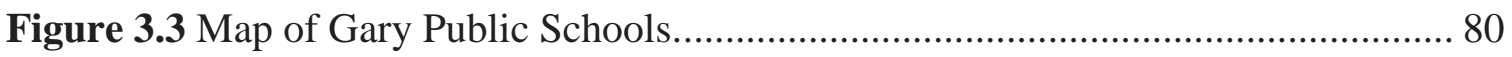

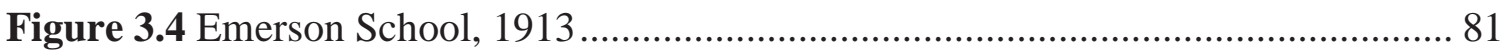

Figure 3.5 Emerson School First Floor Plan, ca. 1914 ................................................ 82

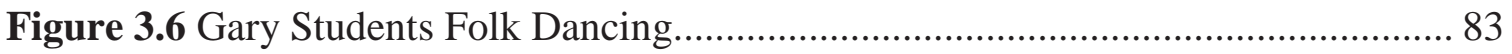

Figure 3.7 Froebel School, 1913 .......................................................................... 84

Figure 3.8 Froebel School Ground Floor Plan, ca. 1914 ............................................... 85

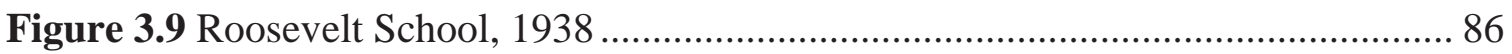

Figure 4.1 Two Generations of U.S. Steel Danger Signs ............................................. 109

Figure 4.2 Screen captures from "An American in the Making," 1913.......................... 110

Figure 4.3 The Gary Young Men's Christian Association (YMCA), 1913 .................... 111

Figure 4.4 Labor Day Track \& Field Meet at Gleason Field, 1920 ............................... 112

Figure 4.5 Gymnasium, American Bridge Works Employee Clubhouse, ca. 1920 ...... 113

Figure 4.6 Illinois Steel Company's Welfare Center, 1921 ......................................... 114

Figure 4.7 Map of Gary Settlement Houses and Welfare Centers................................ 115

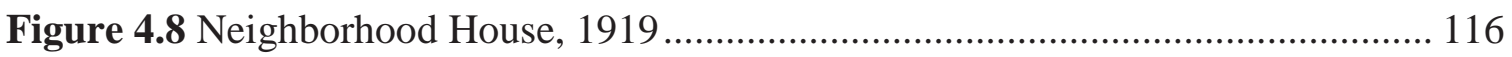

Figure 4.9 Gary-Alerding Settlement House, 1924 ................................................ 117

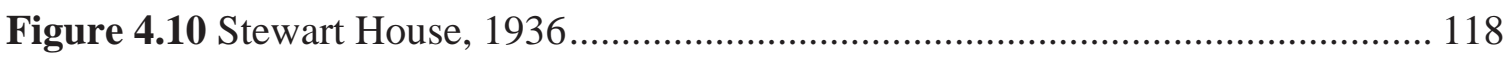




\section{List of Tables}

Table 3-1 Typical daily schedules in the Platoon System categorized by grade level and

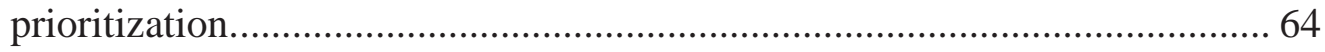




\section{Acknowledgements}

This thesis is the culmination of years of esteemed influences, invaluable assistance, and saintly patience. I extend my sincerest gratitude to all who have contributed to this effort. First, I would like to thank my advisor, Dr. Steven A. Walton, for accepting me as his first graduate advisee at Michigan Technological University; without his guidance and faith in my abilities, none of this project would have been possible. Thanks also to my committee members, Dr. Bradley H. Baltensperger and Dr. Carol A. MacLennan, for their continued direction and flexibility.

The research that supports this thesis was done largely during my time as an ethnographic intern for the Calumet Contemporary Urban Collections project of the Field Museum of Natural History in Chicago. I extend my thanks to the staff of the Science Action Center at the Field Museum, including Dr. Alaka Wali, Dr. Mark Bouman, Mario Longoni, and Madeleine Tudor, as well as Dr. Carolyn Schiller Johnson of the University of Chicago. My fellow Calumet interns Courtney Baxter, Max Lenik, and Wren Wilson remain valued colleagues. Additionally, former colleague and dear friend Garrett Cotter aided me with this thesis' photography.

The relationships built through researching this thesis will forever enhance my drive to seek out the individual narrative in order to understand the hard data. Thanks foremost to Stephen G. McShane of the Calumet Regional Archives, and Dr. James B. Lane of Indiana University Northwest in Gary. Without their continued support, much of this research would not have been possible. I would also like to recognize the assistance and amity of the Calumet Heritage Partnership, Southeast Chicago Historical Society, and Dr. Christine J. Walley of the Massachusetts Institute of Technology. I cannot forget the friends I made in Gary, and at St. Hedwig Roman Catholic Church in Gary, ProCathedral of St. Michael Ukrainian Orthodox Parish in Hammond, Purdue University Calumet in Hammond, and District 7 Steelworkers Organization of Active Retirees in Chicago. All of you have always made me feel welcome, treated me with respect, and affirmed that Gary and the Calumet Region are my home away from home, and for that I cannot thank you enough.

I must also thank my graduate colleagues in the Department of Social Sciences at Michigan Technological University. Dr. Marc N. Henshaw kept me focused and firm in my convictions. Sean Gohman guided my mapmaking twice over. John D.M. Arnold, AIA, gave me excellent architectural advice. Alumni Renée Blackburn, Natiffany Mathews, Alejandra Biehl, and Jessica Peterson provided me a model for writing with grace through the inevitable stress. Thanks are due to my entire cohort, as you've all contributed to my success in your own way.

Finally, and most importantly, I extend my thanks to my family for their good humor, patience, and faith that I had something important to share with the world once this long process was through. Thanks especially to my mother, Marcia Manning Griskavich, for her incomparable copy-editing skills. My love for-and awe of-my family is unending. 


\begin{abstract}
Gary, Indiana is a city with indelible ties to industrial paternalism. Founded in 1906 by United States Steel Corporation to house workers of the trust's showpiece mill, the emergence of this model company town was both the culmination of lessons learned from its predecessors' mistakes and innovative corporate planning. U.S. Steel's Progressive Era adaptation of welfare capitalism characterized the young city through a combination of direct community involvement and laissez-faire social control. This thesis examines the reactionary implementation of paternalist policies in Gary between 1906 and 1930 through the purviews of three elements under corporate influence: housing, education, and social welfare. Each category demonstrates how both the corporation and citizenry affected and adapted Gary's physical and cultural landscape, public perceptions, and community identity. Parallel to the popular narrative throughout is that of Gary's African-American community, and the controversial circumstances of this population's segregated development.
\end{abstract}


"Go into the plants and you will see men sitting around doing nothing - machinery does everything," said the Mayor of Gary when I asked him about the 12-hour day and the 7-day week. And he wore cool cream pants, the Mayor of Gary, and white shoes, and a barber had fixed him up with a shampoo and a shave and he was easy and imperturbable though the government weather bureau thermometer said 96 and children were soaking their heads at bubbling fountains on the street corners. ${ }^{l}$

\section{Chapter 1: Tapping the First Heat of a New Paternalism}

From its inception in 1906, the city of Gary, Indiana, has been inextricably tied to the whims, fates, and fortunes of the United States Steel Corporation. The development of Gary serves as one example of many such towns in the United States, and indeed the world, built by corporate paternalism. As it was, however, the story of Gary is not a typical story of corporate control and benevolence existing in fraught tension with one another. By viewing the company town's history through the industrial paternalistic trinity of its urban planning and housing, educational system, and social welfare programs, it is possible to trace the development of U.S. Steel's changing attitudes and definitions of welfare capitalism and industrial relations. In an era of aggressive social reform and rapid capitalist expansion, Gary served as a model for progressive industrial community-building. This model, however, was an unwitting one, subject to corporate necessity, reactionary policy-making, individual agency, and contemporaneous social mores. As such, Gary, Indiana changed the paradigm of monoeconomic company towns by adapting — and adapting to — public perception, tangible and intangible landscape, and the formation of individual and group identity.

Transforming the industrial community from an oligarchic utopian company town to an urban city where necessity met negotiation was not perfect in any way. Where a desired model for such a settlement did not exist, one was forged extemporaneously in the neighborhoods, schools, mills, and social institutions of Gary. Poet Carl Sandburg attempted to encapsulate the polarity that such constant reification prompted in his vignette of mayoral disconnection from life outside of City Hall. This early example of the influence of perception on policymaking echoed most distinctly into the treatment of Gary's African-American population. U.S. Steel took care to appear as unitarist industrial paternalists, ostensibly maintaining the same "best interests" as their employees. However, in dealing with their black laborers, the paternalism became far more explicit, approaching that which the steel trust had sworn to avoid. In Gary's black community,

\footnotetext{
${ }^{1}$ Carl Sandburg, "The Mayor of Gary," in Smoke and Steel (New York: Harcourt, Brace and Company, 1921), 25.
} 
this new model became a reinterpretation of popularly-held racial stereotypes, creating opportunity for internal recontextualization and individualized success.

\section{Industrial Paternalism and Welfare Capitalism in Company Towns}

The phrase "company town" elicits varying definitions based on industry, geography, time, and population. Many social scientists default to the definition provided in 1930 by the Encyclopedia of Social Sciences, which describes a company town as "a community inhabited chiefly by the employees of a single company or group of companies which also owns a substantial part of the real estate and houses." 2 This broad definition fails to account for a number of additional definitions, such as extant towns that later became dominated by a single industry or corporation, monoeconomic towns developed by private enterprise, company settlements within or adjacent to established cities, and more. What can be agreed upon, however, is that the company town exists as a means to both house and appease the workers of a locally dominant industry. An early example of this that will be expanded upon in Chapter 3 is that of Lowell, Massachusetts, in the mid-nineteenth century, famous for its prolific textile mills staffed largely by young women. These farm girls-turned-millworkers were housed by their employers out of necessity, and any fears held by their distant families were assuaged by the offer of regulated moralizing influences including church services, lectures, literary groups, and sewing circles. The compulsory nature of these offerings, however, also fostered an environment characterized by "enforced benevolence." This struck the first chords of institutionalized paternalism in American industry.

Industrial paternalism in nineteenth-century America took several shapes centered around a standard of company oversight. Broadly put, the top-down form of labor relations sought to control workers' behavior both on the job and in the home. Housing served as a baseline for this control, as the threat of losing a basic human necessity on the grounds of insubordination or immorality was thought to serve as an effective motivator for proper behavior and efficient work. Other programs that constituted this corporate benevolence were dependent on the priorities of the corporation instituting them, including publicly-accessible green space, exercise courses, childcare, and food provisioning. Above all, industrial paternalism was meant to promote the best interests of the corporation while simultaneously accounting for and influencing the intentions of their employees. The end result was to have reasonably content, efficient, and quiet workers both on and off the job. Consequently, and especially after 1880, industrial paternalism was a bald attempt to bribe or cajole workers into having a positive attitude towards the company in an effort the head off any attempt on the part of the workers to unionize.

The benevolent formula of industrial paternalism, however, was shortsighted. The oversimplification of human desires upon which such policies were based did not account

\footnotetext{
${ }^{2}$ Horace P. Davis, "Company Towns," in Encyclopedia of the Social Sciences, vol. 4. (New York: The Macmillan Co., 1930), 119.
} 
for worker agency. The outright paternalism of the nineteenth century was proven outmoded by heavy-handed reactions to enacting this agency. Violent corporate responses to labor uprisings caught the nation's attention, and inspired a call for a "middle ground" in labor relations. Early in the Progressive Era, social reformers convinced many large corporations that this middle ground laid in a more holistic betterment of their employee's lives. Measures were proposed to provide workers with mortgage assistance, health care, job safety, as well as domestic science courses for their wives and education for their children. These welfare programs appealed widely to corporate heads who saw it as an ideal way to build employee loyalty and avoid organized labor. Through this plan of providing comfort and improvement beyond that required by law, the employer and employee would enjoy a mutual advantage through complimentary interests. Dubbed "welfare capitalism," this form of enlightened paternalism stood as the norm in corporate labor relations until choked by the Great Depression. ${ }^{3}$

\section{Previous Research and Literature}

The influences, implementations, and results of industrial paternalism and welfare capitalism have opened a ripe field of research since the mid-twentieth century. Modern researchers continue to refer to American Welfare Capitalism: 1880-1940-economic historian Stuart D. Brandes' 1970 treatise on the historic and financial effects of paternalism in the Progressive Era-as the first comprehensive overview on the subject. Similarly, architectural historian Margaret Crawford's book Building the Workingman's Paradise: The Design of American Company Towns is widely regarded as a guide for interpreting the vernacular architecture and city planning of company towns. In its introduction, Crawford argues that such analysis "portrays the built environment of the company town not as a static physical object, but as the product of a dynamic process, shaped by industrial transformation, class struggle, and reformers' efforts to control and direct these forces." 4

This model for the interpretation of paternalistic company towns has influenced several case studies that broaden the literature on industrial communities. In 2010, preservation historian Alison K. Hoagland published Mine Towns: Buildings for Workers in Michigan's Copper Country, which details how the vernacular architecture of mining settlements in Michigan's Keweenaw Peninsula can be "read" to detail workers' relationships with mine management. The remoteness of the mine locations, combined with a large immigrant population and harsh environmental conditions contribute to a modified, though largely traditional form of industrial paternalism that remained in place

\footnotetext{
${ }^{3}$ It should be noted that the term "welfare capitalism" is used in strictly historic sense, pertaining exclusively to the first third of the twentieth century, in this thesis. It should not be mistaken for any later definitions, including Nixon-era and Clinton-era plans for government-mandated, employer-supplied health insurance.

${ }^{4}$ Margaret Crawford, Building the Workingman's Paradise: The Design of American Company Towns (New York: Verso, 1995), 1.
} 
far longer than in many other American company towns. The transition to Progressive Era-influenced labor relations is characterized in landscape historian Arnold Alanen's Morgan Park: Duluth, U.S. Steel, and the Forging of a Company Town. This 2007 book describes how proactive city planning and dynamic social reforms made a small Minnesota company town a showpiece of localized welfare capitalism. Established in 1915 by U.S. Steel, the modern mill town enjoyed the benefits of knowledge gained in the planning of Gary, Indiana, and Fairfield, Alabama, as well as outside developments such as Cleveland-Cliffs Iron Company's "model town" at Gwinn, Michigan, and the deterrent example of Pullman, Illinois.

The cautionary tale of Pullman is encapsulated in historian Stanley Buder's 1967 book Pullman: An Experiment in Industrial Order and Community Planning, 1880-1930. While touching on the previously-mentioned architectural model, Pullman focuses more on the whole-cloth history of the company town and subsequent iconic labor strike in 1894. Buder strove to objectively represent all perspectives in this straightforward history, including those of company administrators and city planners alike. This style is expanded upon in historian Larry Lankton's Hollowed Ground: Copper Mining and Community Building on Lake Superior, 1840s-1990s, which details the historic narrative of nearly two centuries of copper mining on Lake Superior's southern coast, with attention paid to the technical, financial, and geographical aspects of the business. However, Lankton adds to this by exploring a variety of facets of industrial communitybuilding in the mining district, and how paternalism, ethnicity, and market decline continuously redefine a company town.

These themes of constant re-adaptation to changing policies, populations, and market demand color the existing literature on the history of Gary, Indiana, as well. In 1986, historians Raymond A. Mohl and Neil Betten co-authored Steel City: Urban and Ethnic Patterns in Gary, Indiana, 1906-1950. The book characterizes the multifaceted social and industrial history of the company town as a microcosm of urban growth and change steered by the exponential rise and decline of the American steel industry. The cultural developments that parallel these phenomena are what distinguish Gary from other company towns, which constitute the flesh of historian James B. Lane's City of the Century: A History of Gary Indiana, and Steel Shavings, a yearly regional social history magazine. The narrative style of Lane's recounting of Gary history is supplemented with anecdotes plucked from archival documents and ethnographies collected by Indiana University Northwest students under his tutelage.

Oral history also plays a strong, though muted role in the transmission of the social history of Gary. In 1981, Harvard University folklorist Richard M. Dorson completed his analysis of a six-month survey of local culture and lore in northwest Indiana, and published it as Land of the Millrats: Urban Folklore in Indiana's Calumet Region. A cross-section of a contemporary local population provided anecdotes and opinions on living and working in and around Gary. Much of this touched on the legacy of industrial paternalism in the community, as well as ethnic and racial divisions, and the pride (and peril) that they frequently posed. The collection of interviews continues today 
through the Calumet Contemporary Urban Collections program through the Field Museum of Natural History in Chicago.

The story of ethnic pride and racial marginalization is an essential, and often painful, element in twentieth century American history. In Gary, these stories have been told by citizens with firsthand experience. Lifelong Garyite John Trafny documented the journey of identity formation among Gary's Poles in The Polish Community of Gary, published in 2001. The narrative of the Polish community finding a common purpose, establishing an ethnic enclave, and adapting to industrialized American definitions of success parallels that of Gary's black community. This perspective was gained starting in 1967 by former Gary librarian Dharathula J. Millender in her self-published book, Yesterday in Gary: A Brief History of the Negro in Gary. This detailed history traces the growth of Gary's black community starting in 1906 with African-American construction workers who helped build the fledgling city. Millender expanded on this general history in 2003 with Gary's Central Business Community, illustrating the establishment of a separate commercial market made by and for Gary's black community. These early indicators of the development of a black middle class reasserted the status of Gary as a microcosm of capitalist American society, replete with contemporary social mores, and as an ideal example of the application of welfare capitalism in an industrial community.

\section{Research Design}

Where previous research has focused on specific topics or approaches over a broad timespan, the aim of this research is to examine and synthesize the details of three aspects of welfare capitalism in Gary in only the first three decades of the city's establishment. This thesis combines archival research with anthropological fieldwork conducted under the auspices of the Calumet Contemporary Urban Collections project of the Field Museum of Natural History in the summer of 2013.

\section{Archival Research}

The Calumet Regional Archives at Indiana University Northwest in Gary provided the majority of the documentary research material for this thesis. Within their inventory, the U.S. Steel Corporation Collection provided information about past and present technological developments, fiscal metrics, and labor relations specific to Gary Works. Department newsletters, special event programs, and deed and mortgage paperwork were among the valuable primary sources in the collection. This was supplemented by programmatic documents and photographs from the Gary Neighborhood House Records collection. Additionally, microfilmed historic editions of local newspapers were available here to provide contextual data on contemporary public opinion and community events.

Historic Chicago Daily Tribune articles on the early development of the steel industry in the Calumet Region are made available through the ProQuest Historical 
Newspapers database. Genealogical database Ancestry.com provided both American federal and international census data that fleshed out the chapters' case studies; individuals' details between the decades were gleaned from the website's digitized collection of city directories. Sanborn Fire Insurance Maps of Gary, providing spatial context and architectural details, were openly accessed through Indiana University Bloomington Libraries' Indiana Maps Collection. Similar open access to the Pittsburgh Iron \& Steel Heritage Collection of the Carnegie Library of Pittsburgh's Digital Archive supplied a full compendium of U.S. Steel's Bureau of Safety, Sanitation, and Welfare annual Bulletins. These bulletins proved an invaluable resource for insight into the image of conscientious welfare capitalism U.S. Steel wished to project to the public, featuring detailed reports on plant safety, worker housing, and community health and education.

In this thesis, archival research is used to qualify assertions about the reciprocal nature of industrial paternalism in Gary, Indiana. Historic documents support the argument that U.S. Steel proactively sought to avoid the appearance of old-fashioned autocratic paternalism, while simultaneously stressing the importance of moral hygiene, Americanization, and community standardization. Those not produced by the corporation, including newspapers, maps, and the records of private citizens and organizations, provide a counterpoint that indicate the effect their perceptions of company policy had on future community involvement.

\section{Ethnographic Fieldwork}

Between May and August of 2013, I served as an ethnographic intern for the Calumet Contemporary Urban Collections project of the Field Museum of Natural History in Chicago. Their ongoing project focuses on how cultural and environmental heritage affects individual and group identity and place-making in the Calumet Region. The program's primary strategy is the solicitation of oral histories and material culture artifacts that aid in the interpretation of regional industrial community culture. For this thesis, oral histories from the Field Museum project did not serve as prime sources, but it does make use of the accompanying participant observation fieldwork. This practice involved participating in community events, shopping and dining regionally, and interacting with locals whenever possible.

My experience living and working in the Calumet Region frequently focused on Gary, less than one mile from where I lived during the internship. Participant observations here included joining the multiracial members of an historically Polish Roman Catholic church for a visit to the festival of an historically Croatian Roman Catholic church, attending an environmental summit sponsored in part by U.S. Steel's competitors, and becoming a regular at a mill-adjacent diner frequented by steelworkers and city officials alike. I applied the contextualist Boasian approach to my ethnographic experience, based upon his argument regarding the lasting effects of external influence on society: 
The character of men [is the result of] its development under the influence of the surroundings. 'Surroundings' are the physical conditions of the country, and the sociological phenomena, i.e. the relation of man to man. Furthermore, the study of the present surroundings is insufficient; the history of the people ... must be considered. ${ }^{5}$

The aim of this immersive fieldwork was to observe how Gary's current population lives within the cultural and geographic environment of their own heritage. Many citizens are third and fourth generation Garyites, and live within a habitus shaped by their, and their families', negotiation of life in this model company town. Synthesizing this qualitative data with historic documents and archival data provides a clearer understanding and interpretation of welfare capitalism in the "Magic City of Steel."

\section{Thesis Organization}

The objective of this thesis is to address how Gary, Indiana, is a distinct model of a modern paternalistic industrial community. The conclusion of this introductory chapter situates the city in a region of marked industrial growth focused on raw and finished steel production, in the late nineteenth century. Its advantageous proximity to Chicago, and links to rail and lake traffic made the previously unproductive land an ideal candidate for industrial expansion. When the land was chosen as the site of U.S. Steel's newest mill town at the turn of the twentieth century, plans for the city ranged from streets and homes to moral and intellectual uplift of the city's population.

Chapter 2 introduces the first of three lenses through which the thesis views industrial paternalism and welfare capitalism in Gary, Indiana: housing. Where residential and municipal infrastructure did not exist prior to the arrival of the steel mill, U.S. Steel took advantage of this veritable "clean slate" on which to construct a town balanced between industrial necessity and Progressive Era "middleground" paternalism. The shape that this took engaged both contemporary trappings of "the American dream," and commonly-held ethnic and racial stereotypes.

Chapter 3 reveals that such elements of middle-class aspirations and social categorization were reified within the school. However, these difficulties were tempered by forward-thinking designs in both school layout and pedagogy. The influence of corporate paternalism in the Gary schools was far less direct than in other industrial communities, but was instead made quietly present in the nearly scientific management of school day operations. The establishment of the school as a place of life-long, careeroriented learning for all citizens overlaps with the burgeoning role of social welfare programs detailed in Chapter 4. The rapid expansion of both corporate and faith-based welfare agencies around Gary served as hubs for recreation, health, and family services. Following World War I, these foci were overshadowed by aggressive Americanization

${ }^{5}$ Franz Boas, "Museums of Ethnology and Their Classification (rebuttal)," Science 9, no. 228 (1887): 588. 
initiatives. With the strong encouragement and financial backing of U.S. Steel, these programs included classes in English, citizenship, and even domestic science and parenting. Such efforts were aimed at immigrants both international and domestic. The thesis concludes with an analysis of these lenses viewing the first twenty-four years of life in Gary, and a discussion of recurrent themes found in all.

Introducing each body chapter of this thesis is a small vignette relating an early Gary family to its subject: the John H. Smiths, a small African-American family transplanted from Arkansas and Missouri, who were active and astute participants in the city's housing, educational, and social welfare systems. The Smiths serve as a foil for the average Gary Works employee experience, and as a personification of the burgeoning black middle class in Gary. Just as the parallel narrative of the African-American experience is a recurrent theme throughout this thesis, so too are the Smith family.

\section{Introducing the "Steel City" to the Calumet Region}

The North Chicago Rolling Mill introduced Chicago to industrial heavy iron manufacturing in 1857. Located on the outskirts of the city along the banks of the North Branch of the Chicago River, the plant employed two hundred men rolling iron rails to supply Chicago's expanding position as a rail hub, the first tracks having been laid there in 1848. Varying accounts suggest that some of the first steel rails rolled in America were produced here in 1865, and that the later addition of a Bessemer furnace signaled the firm's conversion to all-steel production. Fifteen years later, the North Chicago Rolling Mill expanded to a new location south of the city. Finding plentiful cheap land adjacent to lines of rail and water transport, the new steel facility became part of the established bastion of industrial success along the Calumet River, which feeds into Lake Michigan at its southernmost tip. ${ }^{6}$

Steel officially arrived in the Calumet Region in the summer of 1875 with the opening of the Joseph H. Brown Iron and Steel Works. Riding high on the success of his first steel mill purchased speculatively in Youngstown, Ohio, Brown established a rolling mill on the west bank of the Calumet River in South Chicago. With the help of a quarter million dollars in federal investment, the mill's cornerstone was laid with much fanfare on July 5, 1875. ${ }^{7}$ Special excursion trains delivered guests of the Town of Hyde Park from Chicago's Palmer House Hotel to the Calumet River in Riverdale, Illinois. Five hundred invitees were ferried to the mill site via steamship for an afternoon of speeches, music, and a benediction.

Local dignitaries orated upon the advantageous location of Brown's Steel Works in South Chicago. A local magistrate lamented the development of Chicago along its

\footnotetext{
${ }^{6}$ Mark R. Wilson, Stephen R. Porter, and Janice L. Reiff, Encyclopedia of Chicago, s.v. "North Chicago

Rolling Mill," 2005, http://www.encyclopedia.chicagohistory.org/pages/2793.html.

${ }^{7}$ Beatrice Lumpkin, "Always Bring a Crowd!": The Story of Frank Lumpkin, Steelworker (New York: International Publishers, 1999), 78.
} 
eponymous river, stating that had the city's founders realized the Calumet River's connection to "the commerce of the Northwest [Territory]," the great city's young history could have been topographically different. ${ }^{8}$ Such sentiment had been first recognized by the Army Corps of Engineers in 1833, when surveyors recommended the river mouth as a harbor. Fifty years later, area investors successfully lobbied congressional funds to improve the delta, and have it designated a Port of Entry. Shortly thereafter, Brown broke ground on his riverside steel works, citing rationale similar to the developers of the North Chicago Rolling Mill: plentiful land, access to transportation lines, (Haig 1917) ${ }^{11}$ and proximity to Chicago's labor force. One additional attraction, however, was the nearby outcroppings of coal discovered by regional boosters. The establishment of Brown's rolling mill nearby, and his purported willingness to "eat all the coal found on the Calumet," was given as proof of the coal vein's value. ${ }^{9}$ This potentially aggrandized account of area natural resources that came from local speculators and investors abetted the developers' interest in the marshy lands of South Chicago.

Four months after the laying of Brown's cornerstone, the first shipment of ore and pig iron arrived at the rolling mill. Following the manufacturer's initial successes, however, the mill changed hands twice in the next twenty-five years. In 1902, the rolling mill was purchased by the newly consolidated International Harvester Company. Renamed Wisconsin Steel, the manufactory functioned as a captive producer of steel for its parent company's agricultural equipment and automotive assembly plants until its 1980 bankruptcy. ${ }^{10}$

Brown Iron and Steel faced stiff competition on the eastern seaboard from Carnegie Steel. Founded in 1873 by self-made tycoon and Scottish immigrant Andrew Carnegie, the Carnegie Steel Company started in Pittsburgh on solid economic ground with funding from its president's successful railroad and oil investments. After learning of the metallurgical and economic advantages of the newly introduced Bessemer steelmaking process, Carnegie broke ground in nearby Braddock, Pennsylvania, for the massive J. Edgar Thomson Steel Works. Named for the former Pennsylvania Railroad president, Carnegie paid tribute to his former mentor by quickly outpacing all of his domestic and British competitors. So much was the breakneck pace of this turnaround that the mill rolled more than 30,000 tons of steel rails during its first year of production. ${ }^{11}$ Within twenty years, Carnegie Steel had purchased numerous competitors and suppliers, placing a vertically integrated stranglehold on regional steel production.

By the turn of the century, steel had firmly planted itself in the Calumet Region with the establishment of another mill, Federal Steel, bankrolled by New York-based financier J.P. Morgan. His desires to capitalize on the expanding demand for steel in the

\footnotetext{
8 "Iron and Steel: Laying the Corner-Stone of the Joseph H. Brown Works," Chicago Daily Tribune, 6 July $1875,1$.

9 "Chicago Coal-Fields: Discovery of Paying Veins Near the Calumet," Chicago Daily Tribune, 13 May 1875,13

${ }^{10}$ Lumpkin, "Always Bring a Crowd!", 78.

${ }^{11}$ William R. Jones, "Description of the Plant at Edgar Thomson Steel Works," in Edgar Thomson Works Letterpress Copy Book (Pittsburgh: Edgar Thomson Works, 1877), 283-288.
} 
Midwest and to broaden his investments quickly led him to a partnership with former jurist and director of Illinois Steel, Elbert H. Gary. ${ }^{12}$ (Figure 1.1) In Judge Gary, Morgan found a shrewd, experienced steel man familiar with federal regulations and the economic climate of his native Chicago. Illinois Steel was quickly swept under the Federal Steel umbrella, and Judge Gary made company president.

In 1900, America's hunger for steel exploded, and the heads of the industry responded by joining forces. That December, Carnegie Steel president Charles Schwab delivered a speech at the New York University Club outlining the formation of a steel trust that placed Carnegie and Federal Steel at the center of an orbit of smaller steel, supplier, and transportation firms. By February 1901, an agreement arranged largely by Judge Gary supplied Andrew Carnegie with bonds and stocks worth \$492 million dollars in exchange for his steel interests. Along with Carnegie Steel, specialty steel firms American Bridge Company, American Sheet Steel Company, American Steel Hoop Company, American Steel \& Wire Company, American Tin Plate Company, National Steel Company, and National Tube Company, and ore supplier Lake Superior Consolidated Iron Mines were brought into the fold.

On February 25, 1901, America's first billion-dollar company was incorporated as the United States Steel Corporation. Charles Schwab was named president, and Elbert H. Gary chairman of the board of directors. However, only two years into the new venture, Schwab left the trust in order to build young Bethlehem Steel into his former employer's largest competitor. With Elbert H. Gary at the helm, United States Steel found success in his belief that the trust's formation was not equal to a monopoly, but rather fostered healthy competition by stressing economy and efficiency. Critics of this view were silenced by the firm's incredible $\$ 423$ million dollar profit in its first fiscal year. Following another four years of unprecedented success and further acquisitions, Gary brought his focus closer to home. ${ }^{13}$

In 1905, U.S. Steel enjoyed one of its most successful years to date. To accommodate the growing demand for steel, company officials began searching for a place to locate a new mill central to this market. ${ }^{14}$ Despite the fact that the Illinois Steel Company, a subsidiary of U.S. Steel, had several plants between Milwaukee, Wisconsin, and South Chicago, growing demand for steel construction had outpaced their output and given advantage to regional competitors. After considering several spots between Waukegan and South Chicago, U.S. Steel turned its attention to northwestern Indiana. Its

\footnotetext{
12 Illinois Steel Company was founded in 1889 by the merger of the Chicago area's four largest steel mills: North Chicago Rolling Mill, South Works, Union Steel, and Joliet Iron and Steel. David Bensman and Mark R. Wilson, Encyclopedia of Chicago, s.v. "Iron and Steel," 2005, http://www.encyclopedia.chicagohistory.org/pages/653.html.

${ }^{13}$ The Gale Group, International Directory of Company Histories, vol. 50, s.v. "United States Steel Corporation History," 2003, http://www.encyclopedia.com/doc/1G2-2845400114.html; Kenneth Warren, Big Steel: The First Century of the United States Steel Corporation, 1901-2001 (Pittsburgh: University of Pittsburgh Press, 2001).

${ }^{14}$ Raymond A. Mohl and Neil Betten, Steel City: Urban and Ethnic Patterns in Gary, Indiana, 1906-1950 (New York: Holmes \& Meier, 1986), 11.
} 
border with Illinois had been industrialized over time, pushing the search further east into cheaper, less developed territory.

At the foot of Lake Michigan, among the dunes and marshes surrounding the Grand Calumet River, U.S. Steel's CEO Elbert H. Gary found the ideal location for his new steel mill. (Figure 1.2) Thirty miles southeast of the booming steel market of Chicago, the new mill site was ideally situated for transportation of raw and finished materials: Lake freighters bearing iron ore and limestone from Minnesota and Michigan could sail the Great Lakes and harbor at the deep water port; Appalachian or Illinois Basin coal could be shipped to the mill via one of the five major railroads that belted the region; raw steel could be shipped to finishing plants in Chicago via an extension of U.S. Steel's Elgin Joliet \& Eastern Railway; water for industrial processes was accessible from both Lake Michigan and the Calumet River system; and the massive labor pool in nearby Chicago supplied the workers.

In 1905, U.S. Steel anonymously purchased nine thousand acres of land spanning seven miles of the Lake Michigan shoreline for \$7.2 million. Extending south from the shoreline to the Wabash Railroad tracks over two miles inland, the massive tract became the site of Elbert H. Gary's eponymous Gary Works and the City of Gary, Indiana. Industrial infrastructure was quick in coming, as the Calumet River and major railroad lines were rerouted to accommodate roads granting access to the mill. Seven hundred feet of shoreline was added by infill to make room for massive docks sized for lake freighters. Extensive coke batteries, immense blast furnaces, and the world's longest rail mill quickly hemmed the lakeshore off from the new industrial community of Gary. ${ }^{15}$ The plans for the town were large in scale, including 4,000 lots belted by thoroughfares, rail lines, and green space. However, the residential district's design was to remain utilitarian, reflecting that of the steel mill that dominated its northerly skyline. These early symbols representing Gary's raison d'être would continue to remind citizens what came first—by chronology and importance-for generations to come.

${ }^{15}$ Ibid., 12-14. 


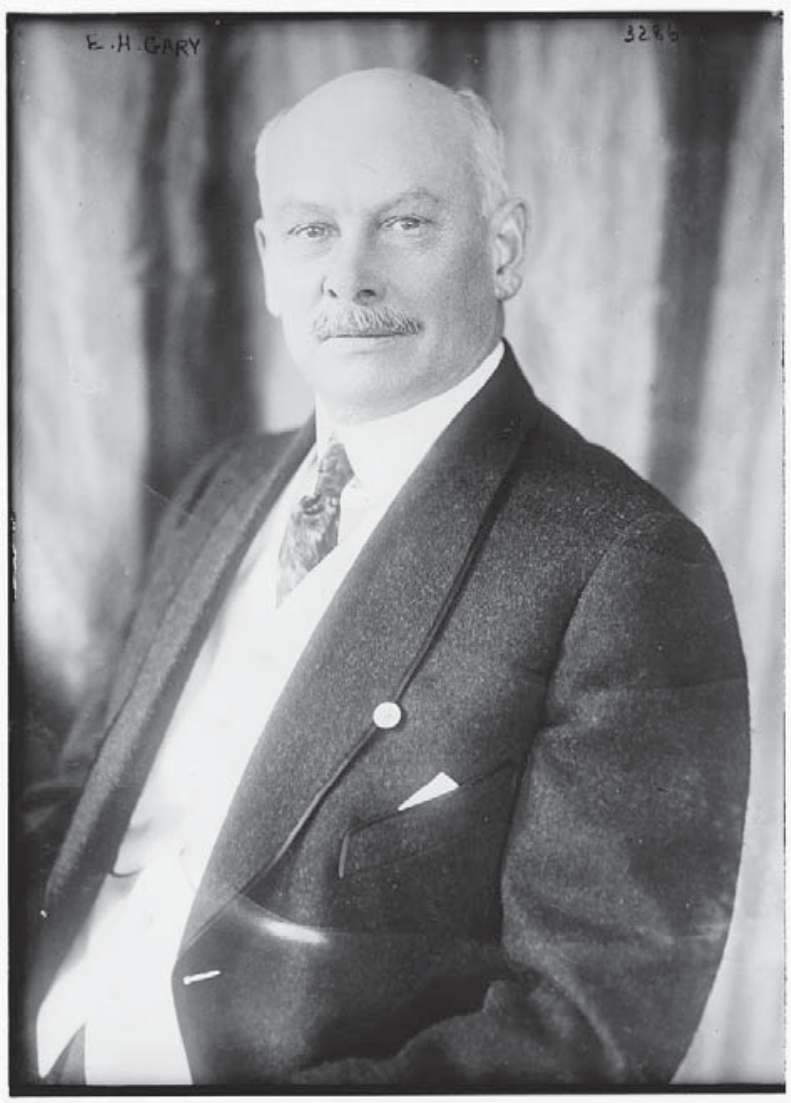

Figure 1.1 An undated photo of Hon. Elbert H. Gary, Chairman of the Board of Directors of the United States Steel Corporation, and namesake of Gary, Indiana. Courtesy of Library of Congress, Prints \& Photographs Division, [LCDIG-ggbain-17737]. 


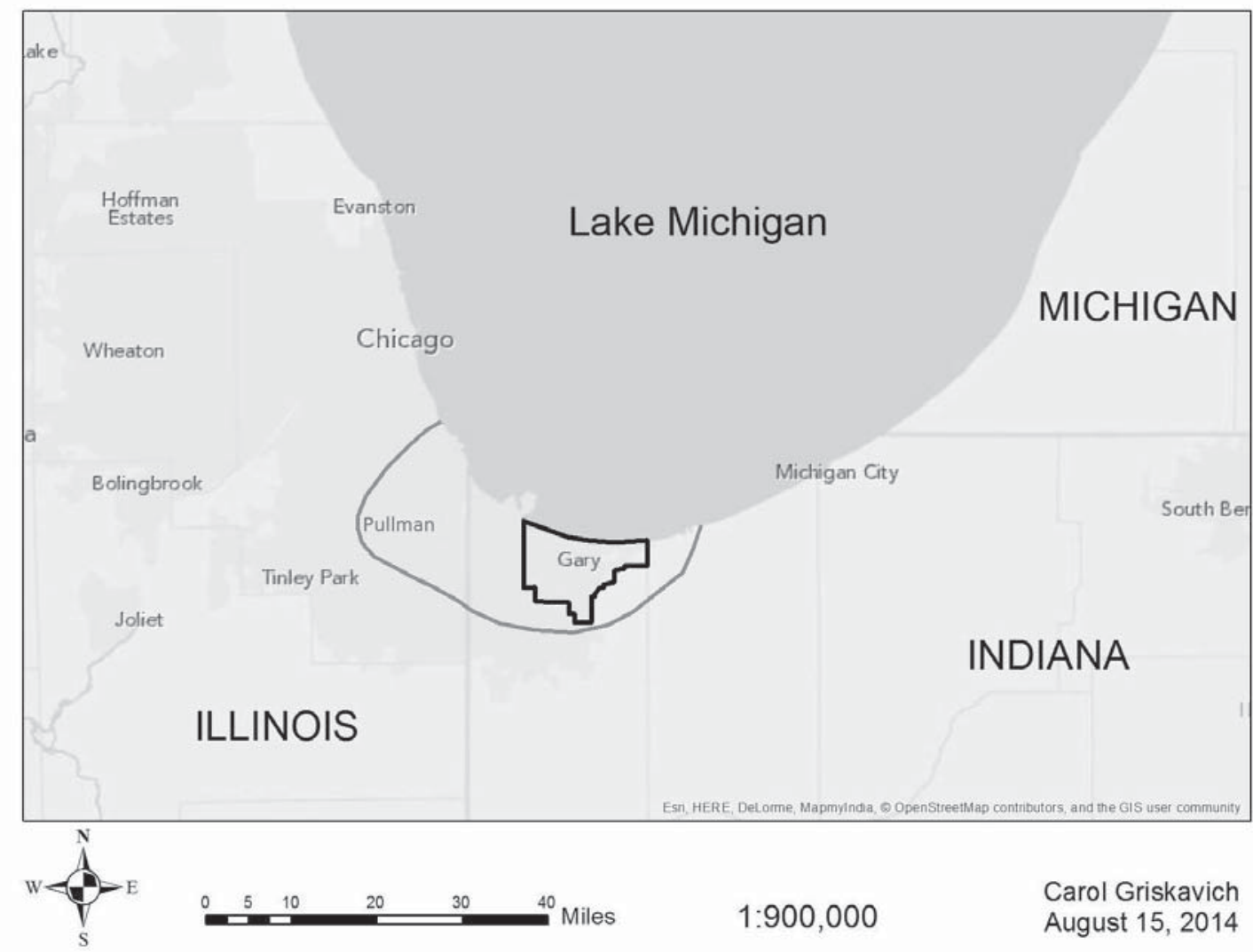

Figure 1.2 The modern boundaries of Gary, Indiana, (black) in relation to the southern shore of Lake Michigan. The approximate boundaries of the Calumet Region (dark gray) vary, depending on who you ask. 

Gary is the truly Aladdinesque city creation of the twentieth century, and without a precedent in character and destiny in the world's history. In the bewildering ensemble are developing beautiful park premises, fairly transformed from the sea of sand, and palatial homes in landscaped environs of velvety lawns...almost incredibly emphasizing Gary's embellishing possibilities. $^{1}$

\section{Chapter 2: Housing a "City by Fiat"}

In 1918, 47 year old John H. Smith moved his family into a small single-family home one block south of the Michigan Central railroad tracks in Gary, Indiana. The Arkansas native, working as a laborer at Gary Works, brought with him his wife Emma and stepdaughter Ella Mae Ross. ${ }^{2}$ Likely having arrived in Gary in answer to the shortage of European immigrants created by the outbreak of World War I, Smith would have found his only family housing options in "The Patch." Located just outside of U.S. Steel's town property, homes in the "unlovely south side" were restricted to hand-built shacks and a number of long one-story frame buildings divided into two-room apartments.

The apartments, built by real estate speculators eager to cash in on the housing needs of eastern and southern European immigrants, often were equipped with a single tap for the entire block of apartments and four privies for twelve families. The crowded, unsanitary conditions faced by both new European, and southern black immigrants like Smith, were borne of unregulated construction and real estate practices outside U.S. Steel's property. Speculators charged up to nine dollars a month for these apartments, necessitating the taking in of boarders who crowded the narrow passageways between buildings and trudged up the muddy, unpaved lanes to work as laborers in the steel mill. ${ }^{3}$

The frontier image conjured by these cramped, spartan facilities was not the case in much of early Gary. Instead, from the marshy swamps and barren dunes rose contemporary brick and frame homes, paved roads, concrete sidewalks, municipal edifices, and modern electric, gas, and sewerage services. A city made to order, this envisioned "Pittsburgh of the West" featured all of the modern amenities that soon changed its motto to "a city useful, a city healthful, and a city beautiful."

By building a new mill in a location with no adjacent extant settlement, U.S. Steel officials knew that they had no choice but to undertake the creation of a town site. The physical landscape at this time included the vacation cabins of the sporty Chicago elite,

\footnotetext{
1 "Gary, Indiana: America's Magic City, 1906-1912," (1912), 3.

${ }^{2}$ Gary, Indiana City Directory, (Indianapolis: R.L. Polk \& Company, 1918), 340.

${ }^{3}$ Elizabeth Hughes, "Infant Mortality: Results of a Field Study in Gary, Ind., Based on Births in One Year," ed. Children's Bureau, U.S. Department of Labor (Washington, D.C.: Government Printing Office, 1923), 66-67.

${ }^{4}$ Mohl and Betten, Steel City, 22.
} 
and a few scattered shacks owned by hunters from Chicago and local fishermen along the eastern dunes of the town of Miller, as well as the small agricultural village of Tolleston and Aetna Powder Company's eponymously named company town. ${ }^{5}$ The nearest large population centers to the projected development included East Chicago nine miles to the west, and Michigan City 26 miles to the east. This made the creation of a settlement an unavoidable necessity.

Incorporated as a city in 1906, the City of Gary rose from the filled-in marshes south of the Grand Calumet River, which separated the town site from the mill that was being built on the leveled glacial sand dunes on the lakeshore. To manage these developments, U.S. Steel established two new subsidiaries: Indiana Steel Company to manage the mill, and Gary Land Company to manage the townsite. The first building in Gary was the Gary Land Company office, a two-story frame building situated just outside Gary Works' main gate. Built in April 1906, the whitewashed, cross-gabled farmhouse housed the first high school courses, the post office, and town hall. ${ }^{6}$ Five months later, it was here that the first city ordinances established the boundaries of the town: nineteen square miles hemmed in by the borders of East Chicago, Clark, Tolleston, and Miller. ${ }^{7}$

\section{Learning from Mistakes, Planning from Successes}

Headed by Armanis F. Knotts, U.S. Steel Gary Works' lawyer, the establishment of Gary Land Company first sought to learn from the mistakes of their paternalistic predecessors in nearby Pullman, Illinois. In 1894, Knotts had served as the Chicago-area lawyer for the Pullman strikers during their system-wide strike. ${ }^{8}$ The experience cultivated in him a keen knowledge of the conditions in which George M. Pullman had failed his eponymous industrial utopia. The comparison of Gary after 1906 and Pullman in the 1890s highlights the changing implementation of industrial paternalistic practices.

Following the Great Upheaval of 1877, Pullman sought to circumvent the "baneful influences" of urban cities on his workers. Stressing the moral and intellectual influences of beauty on the common man, the early plans for his utopian company town reflected those of Sir Titus Salt's mill town, Saltaire, in West Yorkshire. Like Saltaire, Pullman was platted on the periphery of a large industrial metropolis, and visually unified by a single building material and architectural style. Ground was broken for Pullman's company town fourteen miles south of Chicago in 1880, with the majority of the town ready for occupation within four years.

\footnotetext{
${ }^{5}$ Two months after the incorporation of Gary, Tolleston incorporated itself as an independent town in order to circumvent city annexation; it was annexed nonetheless in 1910. Similarly, Miller and Aetna incorporated respectively in 1907; Miller accepted annexation in 1918, and Aetna in 1928.

${ }^{6}$ Historic American Building Survey, "Gary Land Company Building" (Philadelphia: Department of Interior, n.d.).

${ }^{7}$ Isaac James Quillen, "Industrial City: A History of Gary, Indiana to 1929" (Master's thesis, Yale

University, 1942), 114.

${ }^{8}$ Crawford, Building the Workingman's Paradise, 44.
} 
Acclaimed architect Solon S. Beman teamed with landscape architect Nathaniel Bennett to create an ideal garden city to compliment the iconic Pullman Palace Car factory. The town was envisioned as a self-contained suburban community with 1,300 homes, a town market, hotel, interfaith church, theater and shopping arcade, school, and park space. The town was marked by all-brick construction of Queen-Anne, Gothic, and Classical Revival buildings along a gridded street system extending four blocks bounded on the west by the Illinois Central Railroad tracks and on the east by the shores of Lake Calumet.

The grid system of streets was broken up by the central Market Hall, as well as picturesquely-landscaped Arcade Park adjacent to showpiece Hotel Florence. The neighborhood was capped on the north by the Romanesque red-brick edifice of Pullman Palace Car Company's main office building, marked by its renowned forty-foot high clock tower. Beman made efficient use of Pullman's limited space by organizing much of the skilled worker housing into two- to five-family rowhouses distinguished by varying facades and ornamentations. ${ }^{9}$ The brick homes featured modern lighting and ventilation systems, natural gas, running water, and indoor bathrooms. So unusual were these appointments to working-class housing that a company official confidently declared "the building of Pullman is very likely to be the beginning of a new era for labor." 10

The grandeur of Pullman was not based however on capitalist philanthropy so much as on strict paternalistic capitalism. The town was designed as "a business venture pure and simple... Stockholders would get a return, fortunate employees would work harder, and the company would be the beneficiary. Pleasant working conditions would draw out the workers' qualities of honesty, loyalty, and perseverance." 11 George Pullman ran his town from the top down, disallowing local press and elected government. Residents were only welcomed into the community once deemed "of respectable character," and were restricted in their consumption of liquor and tobacco as well as by a curfew. Houses could only be rented in Pullman, and the sale of land or buildings to public or private entities was forbidden. Rent prices guaranteed company investors a six percent return on their investment regardless of employment and wages. ${ }^{12}$ These management tactics created an atmosphere of Pullman's tenants as burdensome guests in their "own" homes, and contributed to the watershed American Railway Union strike in 1894. ${ }^{13}$

Following the economic panic of 1893, Pullman reacted to decreased demand by instituting massive layoffs and wage cuts. Despite this, rent prices in his industrial utopia remained the same in the face of calls for negotiation. George Pullman unequivocally

\footnotetext{
${ }^{9}$ In addition to the row houses, twelve detached single-family homes and ten large tenement buildings increased the residential capacity of Pullman.

${ }^{10}$ Stanley Buder, Pullman: An Experiment in Industrial Order and Community Planning, 1880-1930 (New York: Oxford University Press, 1967), 61.

${ }^{11}$ Hardy Green, The Company Town: The Industrial Edens and Satanic Mills That Shaped the American Economy (Basic Books, 2012), 30-31.

${ }^{12}$ Richard Theodore Ely, "Pullman: A Social Study," Harper's Magazine 70 (1885): 452-466.

${ }^{13}$ Crawford, Building the Workingman's Paradise, 38-40.
} 
dictated that "we are landlord and employers" while insisting on maintaining a separation between the two roles. Bad press followed the conclusion of the Pullman Strike in 1894, including a scathing characterization of the company head by social reformer Jane Addams as "a modern [King] Lear." 14 A federal report by the United States Strike Commission placed the blame firmly on Pullman's shoulders and highlighted the uneven concentration of wealth and workers. Four years later, the Illinois Supreme Court ruled the corporate operation of the town of Pullman in violation of Pullman Palace Car Company's charter of incorporation. By court order, the company divested itself of all non-manufacturing property in Pullman, and the town site was annexed by the City of Chicago. ${ }^{15}$

George Pullman died in 1897, angry and disgraced. The legacy of Pullman carried forward lessons for the establishment of new company towns-by-decree. Seven years after the Supreme Court ruling, American Bridge Company incorporated the borough of Ambridge, Pennsylvania by building houses that they immediately sold to their employees. In 1909, Indiana Steel and Gary Land Company President Eugene J. Buffington wrote of his impressions in Harper's Weekly:

The most successful attempts at industrial social betterment in our country are those furthest removed from the suspicion of domination or control by the employer. Fresh in the minds of all of us is the failure of the Pullman Company to maintain its authority over the village affairs of Pullman. American ideas and atmosphere are inherently antagonistic to such plans of community life. Successful plans for social betterment have recognized the fundamental idea of self-helpfulness as the keystone in the structure of our industrial village life. The American laborer repels and resents any so-called benevolence which assumes to provide him with benefits not attainable by his own efforts. ${ }^{16}$

With these assertions as a baseline, Buffington and the Gary Land Company proceeded to plan their ideal industrial village by culling the finest features of other successful company towns.

Buffington credited Vandergrift, Pennsylvania, as the main model for Gary. Incorporated in 1895 as the company town of Apollo Iron and Steel, the new settlement was the fruit of subsidiary Vandergrift Land and Improvement Company. Seeking to create an environment rooted in conservative welfare capitalism, company chairman George G. McMurty believed that infrastructure planning, social reform, and encouragement of private home ownership would create a loyal, non-union workforce. To design this new "Workingman's Paradise," McMurty travelled Europe visiting

\footnotetext{
${ }^{14}$ Graham Romeyn Taylor, Satellite Cities: A Study of Industrial Suburbs (New York: D. Appleton and Company, 1915); Jane Addams, "A Modern Lear," in Satellite Cities: A Study of Industrial Suburbs, ed. Graham Romeyn Taylor (New York: D. Appleton and Company, 1915).

${ }^{15}$ United States Strike Commission, Report on the Chicago Strike of June-July, 1894 (U.S. Government Printing Office, 1895).

${ }^{16}$ Eugene J. Buffington, "Making Cities for Workmen," Harpers Weekly, 8 May 1909, 15-17.
} 
industrial villages in France, Germany, and Russia. Upon his return, he hired landscape architect Frederick Law Olmsted to lay out the town. Famed for his designs of New York City's Central Park, and the World's Columbian Exposition grounds in Chicago, Olmsted was tasked with fitting a cohesive mill town into the undulating hills of a peninsula in the Kiskiminetas River. ${ }^{17}$

Named after Captain James J. Vandergrift, the primary investor in the Apollo Iron and Steel Company, the company town deviated from a traditional grid layout.

Embracing the meandering landscape of the adjacent river bend, the streets were laid in a curvilinear pattern allowing ample room for landscaped green space in irregularly-shaped lots. Vandergrift Land and Improvement Company provided for modern gas, electric, water and sewer utilities for the entire settlement. The one thing they did not offer was housing; lots were offered for sale to Apollo Iron and Steel employees to construct homes upon as they wished. The sole restriction on building on Vandergrift lots was an embargo on the traffic of intoxicants.

Buffington pontificated on the advantages of McMurty and Olmsted's judicious plan for Vandergrift:

The directing genius of the plan was a practical, sagacious man, having through long experience in industrial and social affairs attained an abiding faith in the ability of the American workingman to work out for himself the best in the art of homemaking and community regulation. The faith in individualistic competence has been abundantly and hopefully justified. Every regulation of that kind was left to the judgment and control of the future citizens of Vandergrift. ${ }^{18}$

Buffington's exuberance over the citizens' involvement in the establishment of building lines, city government, sanitation, schools, and more, exemplified his desire to establish a company town free of totalitarian corporate control. Following Apollo Iron and Steel's amalgamation into American Sheet Steel Company in 1900, and U.S. Steel's acquisition thereof the subsequent year, in 1906 Buffington was free to model the monopoly's newest mill town, Gary, after his prime example.

\section{Gary's Original Layout}

Gary's earliest residences were simple tents and tarpaper shacks whose windswept walls were shored up with the abundant sand of the region. The first stop for many of the city's pioneer citizens was a windowless, 60-cot bunkhouse called McFadden's Flats. The rough conditions, lacking both water and toilet facilities, were available to both men and women for twenty-five cents per night. This stood in stark

\footnotetext{
${ }^{17}$ Anne E. Mosher, Capital's Utopia: Vandergrift, Pennsylvania, 1855-1916 (Baltimore: Johns Hopkins University Press, 2004).

${ }^{18}$ Buffington, "Making Cities for Workmen," 16-17.
} 
opposition to the comparatively opulent lodgings of U.S. Steel's initial agents in Gary; these privileged few took up residence in the quarters of the Calumet Gun Club, the former hunting retreat of the Chicago business elite acquired by the steel firm during their land acquisition. Mill officials were the last people to make use of the clubhouse billiards rooms and rifle range before its demolition to make way for Gary Works' harbor. ${ }^{19}$

Platted south of the Grand Calumet River, Gary was laid out around a T of main streets: Fifth Avenue running parallel to the river, and Broadway running south out of the Gary Works' main gate. The cosmopolitan names of the city's wide main thoroughfares, honoring the iconic shopping and entertainment boulevards of New York City, betrayed the city planners' "pretensions, if not scope" of Gary Land Company's new settlement. ${ }^{20}$ Streets east of Broadway were named for past American presidents in order of their terms, with Washington Street starting the system one block west of the boulevard. East of Broadway, the streets were named after the states of the union. East-west lanes paralleling Fifth Avenue maintained a continuous numbering system.

Professional city planners were not hired to design the City of Gary. Instead, Gary Land Company's chief engineer A.P. Melton laid out the town using a "rule of thumb" plan that platted streets and properties on an unyielding grid expanding outward from the 8,000 square foot $\mathrm{T}$ intersection of the main streets. Contemporary writers pointed to the outmoded nature of the grid plan of urban design, and the peculiarity of its use by Gary Land Company in the city's layout. Not only was Buffington enchanted by Olmsted's work in Vandergrift, but as a member of the Commercial Club of Chicago, he aided in financing Daniel H. Burnham and Edward H. Bennett's Plan of Chicago. ${ }^{21}$ Social reformer Graham Romeyn Taylor described the disconnect between mill and town planning:

The placing of the blast furnaces was dictated by the speed of a laboring locomotive on a curving switch track..."placed at an angle of twenty-two degrees, allowing a 200-foot radius for the entering switch." By such careful computations it was sought to avoid the moment wasted... So much for transporting metal. But a workman who lives a mile away from the mill gate has needlessly to criss-cross the checker-board streets of the town, for a distance easily calculable by the old formula that the square of the hypotenuse of a right-angled triangle is equal to the sum of the squares of the other two sides. ${ }^{22}$

The checkerboard blocks of Gary were bisected by wide alleys beneath which were laid sewer, gas, water, and electrical systems. The engineering forethought of A.P.

\footnotetext{
${ }^{19}$ James B. Lane, City of the Century: A History of Gary, Indiana (Bloomington, IN: Indiana University Press, 1978), 29.

${ }^{20}$ Crawford, Building the Workingman's Paradise, 43; Mohl and Betten, Steel City, 15-17.

${ }^{21}$ Commonly known as the "Burnham Plan," its recommendations included proposals for new wide radial boulevards, rail and harbor facilities, civic centers, and a major increase of park space along the lakefront. The plan became the core of the "City Beautiful" Movement that swept the U.S. over the next two decades. 22 Taylor, Satellite Cities, 8.
} 
Melton was betrayed by the use of such utility corridors to prevent tearing up of streets and private property to perform repairs, as well as a water system capable of serving 250,000 people. Two parks were platted by Gary Land Company: Buffington Park, a onesquare block green space east of Broadway named after the Illinois Steel Company executive, and Jefferson Park, a two-square block parcel west of Broadway, featuring a rare sparing of the contours of extant sand dunes, altered only by the lawn seeding of slough mud spread atop the landscape. The city's first water tower, a finished concrete columnar showpiece, was raised here in $1909 .{ }^{23}$ These initial plans for Gary created a framework on which the city's First Subdivision was built.

\section{Gary Land Company's First Subdivision}

Beginning in September 1906, thousands of construction workers were employed in the establishment of Gary Land Company's First Subdivision. (Figure 2.1) Covering 800 acres bisected by Broadway, the initial development was hemmed by Fillmore Street to the east, and Tennessee Street to the west. Fourth Avenue and the Chicago, South Shore, and South Bend Railroad tracks demarked the northern boundary, and Ninth Avenue and the Wabash Railroad tracks enclosed the south. Lots along Broadway and its immediately adjacent streets, Washington and Massachusetts, were reserved for commercial developments. The approximately 120 -square block area contained entirely macadamized, paved streets flanked by concrete sidewalks and shade trees. ${ }^{24}$

The uniform blocks were six hundred feet long, and each divided into forty lots, each ranging in size from 3,750 to 4,500 square feet. These lots were sold for cost and improvements plus any carrying charges, restricted by two main covenants: manufacture, sale or disposal of intoxicating liquors was barred from the property; and the lot had to be built upon within a set time period. The latter covenant, generally set to between twelve to eighteen months, also dictated that residences built on the plots had to meet a minimum cost of between $\$ 2,000$ and $\$ 5,000$, and to have their design approved by the Gary Land Company. ${ }^{25}$ A variety of home designs were approved, though all were required to share common traits. All homes were required to be a minimum of two stories and a basement, set back on a twenty-five to thirty foot building line. ${ }^{26}$ By November 1907, over fifty different home designs had been permitted and built by the Gary Land Company, totaling 506 dwellings.

In its desire to avoid Pullman's evident paternalism characterized by "rows of cheap cottages built on European lines, emphasizing the workman's limitations," Gary Land Company advertised "a city of homes, each on its own lot and surrounded by its own lawn. Few houses on any block are alike... The desire has been to make the residence streets of Gary resemble those of a city whose property owners had built to

${ }^{23}$ Quillen, "Industrial City: A History of Gary, Indiana to 1929," 118, 173-174.

${ }^{24}$ Buffington, "Making Cities for Workmen," 18; Taylor, Satellite Cities, 182; Pamela Tranfield and

Dorothy Nicholson, "Workmen's Houses, Gary, Indiana Photographs, 1916-1917" (2004).

${ }^{25}$ Quillen, "Industrial City: A History of Gary, Indiana to 1929," 118-119.

26 "Features of the City of Gary, Indiana," Iron Trade Review 41, no. 21 (1907): 839. 
please their fancy." ${ }^{27}$ However, the intended economic functionalism of selling lots to purchaser-occupants was quickly frustrated by sluggish sales. Prices were such that only mill employees with the highest salaries could afford to purchase property and follow the covenants of building an approved house within the allotted time. In fact, by 1909, only 250 privately-built homes had been raised on plots sold by the Gary Land Company.

Realizing the necessity, the company soon began building and selling houses on their own First Subdivision lots. However, this effort proved to be not enough, as these houses tended to be elegant, commodious brick and concrete edifices affordable only to mill executives, foremen, and highly-skilled tradesmen. Early on, many of the mill's top executives worked out of Illinois Steel Company's main office in downtown Chicago, making their residence in Gary unnecessary. Others preferred to commute via train from more established nearby communities.

Gary Land Company addressed this issue by scaling down their housing options. Within ten years of the city's incorporation, a cluster of ninety four- to six-room frame houses was built in the northwestern corner of the First Subdivision. Dubbed Kirkville, the uniform two-story, cross-gable roofed homes were built to house workers at the nearby Chicago, Lake Shore \& Eastern Railway Kirk Yard. ${ }^{28}$ Still, the prices of these homes primarily attracted American-born skilled workers. Few immigrant families could afford to live in Kirkville on the wages of unskilled labor. Again, Gary Land Company reacted by further scaling back their housing designs. ${ }^{29}$

The first permanent housing Gary Land Company provided for the city's burgeoning unskilled immigrant population took root in the northeast corner of the First Subdivision (incidentally as far as possible from the posh homes east of Broadway). Reflecting the ethnicity of the development's target demographic, the area was mantled with the nicknames "Hungary Hollow"—or, more popularly, "Hunkyville." The fifty closely-spaced houses were referred to as "double dry-goods boxes" based on their uniformly rectangular shape. Featuring four rooms - two on each floor-and one bathtub under a square roof, the homes were intended to house a stereotypically large eastern European family. However, the overwhelming proportion of single men in Gary interested solely in a bed meant that such spacious accommodations were still too expensive and unnecessary for the average worker. This reality, combined with immigrant families struggling to afford even the cheapest Gary Land Company houses, created a perfect storm of overcrowded Hunkyville boardinghouses.

In 1909, Taylor reported on the tremendous population density in Hunkyville, stating that "Thirty-eight of the four-room dwellings-142 rooms - at one time contained 428 people." ${ }^{30}$ With multiple lodgers sleeping in shifts, unsanitary conditions abounded

\footnotetext{
${ }^{27}$ Ibid., 837-839.

${ }^{28}$ The Chicago, Lake Shore, and Eastern Railway was acquired by Federal Steel in 1898, which was swept into the formation of United States Steel in 1901. The CLS\&E was leased by U.S. Steel's Chicago-area belt railway the Elgin, Joliet and Eastern in 1909, and the two merged in 1938. Kirk Yard, named after EJ\&E superintendent of terminals John Kirk, is still used today by Canadian National Railroad's Joliet Division.

${ }^{29}$ Mohl and Betten, Steel City, 17-19.

30 Taylor, Satellite Cities, 192.
} 
in the homes on Rhode Island and Vermont Streets. Officials despaired of stories of occupants, unfamiliar with the modern conveniences of the American home, tearing up floorboards to burn for heat and leaving water taps running for fear that shutting them off would prevent them from ever running again. Exasperated, Gary Land Company evicted an estimated 1,200 immigrant occupants from the fifty houses in 1911, replacing them with American-born families who pledged not to take on any lodgers. However, a second round of evictions came two years later to make room for more substantial homes for executives of the planned adjacent American Locomotive Company factory. ${ }^{31}$

Eventually, housing the majority of the labor force became an obvious and unavoidable challenge which the Gary Land Company met by becoming what they had vociferously objected to: corporate landlords. One year after the city's incorporation, Taylor tallied the 506 standing residences in the First Subdivision:

50 frame houses, 4 rooms, renting at $\$ 12$ to $\$ 13$ a month

90 frame houses, 4,5 , and 6 rooms, renting at $\$ 14$ to $\$ 20$ a month

100 frame houses, 6 rooms, renting at $\$ 16.50$ to $\$ 19.50$ a month

266 brick, cement and timber houses, 5 to 10 rooms, renting at $\$ 23$ to $\$ 42$ a month $^{32}$

In these homes, United States Steel and its subsidiary companies sought to offer egalitarian housing to the majority of their employees in the First Subdivision, while ensuring - either by price point, or by the essentialness of their position-that the corporation retained an element of control in who lived there, and how they were housed.

In the following pages, four cases are studied to illustrate both the variety of structures built by the Gary Land Company, as well as the agency and symbolism assigned to them by their owners and occupants. The first two cases are located in the First Subdivision, with one showcasing the stylish substantiality and firmly middle-class trappings of the company's early construction. This is joined by the curious case of terrace homes designed for the poor quietly re-intentioned for imported skilled workers. The final two cases are situated in the Ninth Subdivision, Gary Land Company's blackonly neighborhood. The small, understated houses here include the single-family home owned by John H. Smith, an early investor in the neighborhood and supporter of further self-segregation. The final case of duplexes in the Ninth Subdivision exemplifies a recurrent theme in this thesis: the home recontextualized by Gary's black community as the site of transition from working-class to middle class families.

${ }^{31}$ Mohl and Betten, Steel City, 18-19; Will H. Moore, "If I Had Known" About Gary in 1909 (Chicago: Barnard \& Miller Print, 1909), 46; Quillen, "Industrial City: A History of Gary, Indiana to 1929," 127-129.

32 Taylor, Satellite Cities, 184. 


\section{Van Buren St.}

A block from Jackson Park, 735 Van Buren Street was built in the initial wave of Gary Land Company's residential construction. (Figure 2.2) The Foursquare detached home first appeared on Sanborn Fire Insurance Maps in 1908. The spacious two-story frame home sat on a concrete block foundation atop a full basement. The exterior was clad in four-inch thick brick veneer around its first floor, and Portland cement stucco on its second. The division is visually denoted by a beltcourse flush with the bottom of the second floor windowsills. The home is topped in a hipped roof clad in slate or concrete tiles finished with rolled hip and ridge tiles. The boxed eaves support a full gutter system. The roofline is pierced by a brick slope chimney near the ridgeline, and a small plumbing vent, in the south pitch. Additionally, pitched-roof frame dormers faced with casement windows are centered in the front and rear roof pitches.

Initially, the façade featured a half-width, open frame porch capped by an identical slate or tile hipped roof. Boxed eaves and gutters match the main roof system as well. The system was supported by unadorned square columns with matching whitewashed balustrades. Access to the porch was provided by a set of three wooden steps onto the deck skirted by vertical lathe board. Adornments were limited to ball-style finials on the stoop's newel posts. Fenestration of the house was equally understated, with two closely-spaced one-over-one double-hung windows centered in the front façade of the second floor; a matching window was placed just left of the front porch on the first floor. Varied sizes of similar windows were built into the side and rear walls, all in whitewashed masonry sills.

When constructed by the Gary Land Company, the home was provided with an enclosed half-width rear porch. ${ }^{33}$ The shed-roof frame porch is visible in the 1917 oblique portrait of the home featured in the "A Home Owning Number" Bi-Monthly Bulletin of the American Iron and Steel Institute. Under a subheading of "The American Bridge Company's Plan For Encouraging Home-Owning," the role of the Gary Land Company in this encouragement is described:

In the Gary district, some of the houses were built by American Bridge Company and later turned over to the Gary Land Company to be paid for under the Gary Land Company's selling plan, which calls for 10 per cent payment at the time of purchase and the balance in 120 equal monthly payments with 5 per cent interest on deferred payments. The Gary Land Company has encouraged Corporation employees in building their own homes and have agreed to make loans to

\footnotetext{
${ }^{33}$ Gary, Lake County, Indiana [map]. December 1908. "Sanborn Fire Insurance Maps." New York: Sanborn Map Company, 5; Insurance Maps of Gary, Indiana [map]. January 1911. "Sanborn Fire Insurance Maps." New York: Sanborn Map Company, 10; Insurance Maps of Gary, Indiana [map]. December 1915. "Sanborn Fire Insurance Maps." New York: Sanborn Maps Company, 22.
} 
prospective builders of 75 per cent of the value. These loans bear interest at the rate of 6 per cent. ${ }^{34}$

Featured alongside homes built by and for employees of United States Steel's various subsidiary companies nationwide, the figure was captioned "ELGIN, JOLIET \& EASTERN RAILWAY COMPANY, GARY, IND. Owned by Walter Sullivan, electrical department, 735 Van Buren Street, value \$4,400." 35

Though not the first occupant of 735 Van Buren Street, Walter Sullivan was the home's first owner. Born in rural Blue Hill, Nebraska, Sullivan arrived in Gary with his wife Maybell prior to 1913. By 1917, Walter had left his job as a foreman at Gary Works to be an electrician for U.S. Steel's industrial railroad. ${ }^{36}$ When photographers from the American Iron and Steel Association came to document his house for their summer bulletin, the couple had dressed their home in new, comfortable accessories. Walter and Maybell had screened-in their open porch, allowing them to enjoy it despite the preponderance of mosquitoes in the remaining marshland surrounding Gary. Additionally, they lidded their west-facing windows and front porch in three-point operable awnings. These striped, stylish contemporary solutions to harsh sun against the unguarded masonry face of the Foursquare home were likely made of canvas duck, a popular and affordable material at the turn of the century. ${ }^{37}$ Adding the screens and retractable awnings offered the Sullivans more options in the use of their home, as well as demonstrating their relative wealth to their similarly appointed neighbors.

Though Walter Sullivan made several lateral moves in U.S. Steel throughout his career, he maintained a high standard of living common to those living west of Jackson Park in the First Subdivision. Within two square blocks, he called "neighbor" Indiana Steel Company superintendent W.P. Gleason, EJ\&E Railroad superintendent John Kirk, and - two doors down-Gary Land Company president Capt. Horace S. Norton. This demonstrates the establishment of Gary Land Company's First Subdivision as a settlement made for the city's elite and skilled workers, by the elite and skilled workers. ${ }^{38}$

Walter and Maybell Sullivan left 735 Van Buren Street in the mid-1950s, after more than three decades in their home. Current photographs and observation show that several additions have been made to the home since its official 1917 portrait. At some point in the past 97 years, the front porch was expanded to full-length across the first

\footnotetext{
34 "A Home Owning Number," Bi-Monthly Bulletin of the American Iron and Steel Institute 5, no. 4 (1917): 123.

${ }^{35}$ Ibid., 155. The same image was featured again in BSSW, "Home Owning Plan," Bulletin 9 (1922): 30. The photo, captioned "Walter Sullivan, $1^{\text {st }}$ Helper Open Hearth Gary, Indiana," appeared below that of the John H. Smith house.

${ }^{36}$ Smith's Directory for Gary, Indiana for 1913 (Gary, IN: Edgar Smith, 1913), vol.2, 348; United States Selective Service System, "Walter Frederick Sullivan" (1917), in World War I Selective Service System Draft Registration Cards, 1917-1918, Lake, Indiana, Draft Board 1: Precinct 20, Rec. No. 16, National Archives and Records Administration.

${ }^{37}$ Chad Randl, "The Use of Awnings on Historic Buildings: Repair, Replacement, and New Design," Preservation Briefs 44 (2005).

38 "Gary, Indiana: America's Magic City, 1906-1912."
} 
story. The changed layout maintained the screen-on-frame construction and hipped roof. The roof cladding has been changed to more economical asphalt shingles on both the front porch and main roofs. Additionally, the rear shed-roofed frame porch was replaced with a larger hipped-roof one-story addition. Clad in brick, the rear addition ends in a small enclosed entry porch leading to the rear stoop and concrete path. This path connects to the detached garage at the rear of the property. As the home was built prior to the wide availability of automobiles, and insufficient space between homes was provided, concrete block garages such as this were often added along the alleys of the First Subdivision. These additions, though unprovenienced, symbolize the continued role of homes in the First Subdivision as showpieces for the upper crust of U.S Steel in Gary.

\section{Polk Street Terraces - 402-422 Polk Street}

In 1910, Gary, Indiana prepared for the opening of another massive steel works. Two years prior, U.S. Steel subsidiary United States Sheet and Tin Plate had announced their intention to locate a new mill just west of Gary Works. This development, along with the concurrent opening of the adjacent American Bridge Company's Gary plant, was to bring 3,000 new workers and their families to the city. ${ }^{39}$ As the city braced for this new population influx, representatives of the Gary Commercial Club encouraged inviting regional and distant investors and contractors to expand the private housing stock. This piecemeal effort quickly fizzled, and Gary Land Company scrambled for more options.

Recognizing the urgency of housing needs, U.S. Steel and its subsidiaries again chipped in to fund housing for their imminent wave of new workers. American Bridge Company moved quickly, assigning in-house architect D.F. Creighton to design economical, modern, and comfortable homes for their Gary plant start-up crew. Several detached and terraced houses were swiftly erected outside the mill gates on Ambridge Street. ${ }^{40}$ Creighton's construction reflected earlier First Subdivision frame house designs, clad in stucco and veneered in brick. However, the contemporary popularity of American Craftsman style is evident in the homes' low pitched roofs, exposed rafter tails, and simple adornments. ${ }^{41}$ The houses' uniform designs and simple materials proved to be a shrewd investment for American Bridge Company, built cost-effectively and quickly rented to incoming employees. Facing an imminent wave of management and skilled workers transferring in from their Pennsylvania mills, officials of United States Sheet and Tin Plate took note of their neighbor's success.

At the dawn of the twentieth century, the housing reformers and popular media began touting concrete construction as the panacea to much of America's urban ills: the economical material could allow tenement dwellers their own durable, sanitary, and

\footnotetext{
${ }^{39}$ Christopher Baas, "Concrete in the Steel City: Constructing Thomas Edison's House for the Working Man," Indiana Magazine of History 108 (2012): 257-258.

${ }^{40}$ Since renamed Bridge Street.

${ }^{41}$ Virginia McAlester and Lee McAlester, A Field Guide to American Houses (New York: Alfred A. Knopf, 2006), 453-454.
} 
fireproof homes. Worldwide, contractors and inventors started to experiment with modular concrete construction. The concept finally took off in 1908, when famed inventor Thomas Edison filed a patent for a "Process of Constructing Concrete Buildings." Having invested in the concrete industry seven years prior, Edison pitched what would be a major economic boon to him personally as an equal blessing to the working man:

The object of my invention is to construct a building of a cement mixture by a single molding operation - all its parts, including the sides, roofs, partitions, bath tubs, floors, etc., being formed of an integral mass of a cement mixture. This invention is applicable to buildings of any sort, but I contemplate its use particularly in for the construction of dwellings, in which the stairs, mantels, ornamental ceilings and other interior decorations and fixtures may all be formed in the same molding operation and integral to the house itself. The house thus made is practically indestructible and is perfectly sanitary. The cost of its construction is low and it is feasible to beautify such a house far beyond anything now possible in so cheap a manner. ${ }^{42}$

With Edison's branding, the concept of concrete homes gained momentum. The inventor explicitly spread the idea that providing the working class with private homes removed from the squalor, disease, and discontent of urban tenement living was the answer to the nation's social ills. To support his claims, Edison offered the rights to use his patent to builders willing to let him approve their designs. He followed up this support by patenting a cast-iron modular mold system for his continuous-cast concrete homes. ${ }^{43}$ However, the popular altruistic portrayal of Edison's confidence in his patent procedures was diminished by his proclamation that these homes could be filled with affordable, durable concrete furniture. Regardless, United States Sheet and Tin Plate had workers and families to house, quickly and cheaply.

In 1910, architect D.F. Creighton was called on to design a variety of cast-inplace concrete homes for the incoming employees of United States Sheet and Tin Plate's Gary plant. Permits were secured for the first residential units-four apartment buildings to be built by Chicago contractor Fred M. Stultz-in August of that same year. United States Sheet and Tin secured concrete molds for the project from Milwaukee-based Reichert Manufacturing Company. (Figure 2.3) Known for their continuous-cast silo designs, the family-owned business had patented their modular metal concrete mold system two years before Edison. These 24-inch square panels allowed for foolproof assembly via hand-operated clamp latches and wooden dowels, the latter of which was integrated into the concrete forms; walls could be poured up to one story at a time. The concrete for each home, supplied by nearby Universal Portland Cement Company's

\footnotetext{
42 Thomas A. Edison. 1917. Process for Constructing Concrete Buildings. U.S. Patent 1,219,272, filed 13 August 1908, issued 3 March 1917.

43 Thomas A. Edison. 1915. Mold for Concrete Construction. U.S. Patent 1,123,261, filed 29 December 1908, issued 5 January 1915.
} 
Buffington Harbor plant, was anticipated to total "one [railcar] load of cement, five cars of crushed stone, and two or three cars of torpedo sand." 44

The assembly of one story's worth of steel forms, pouring and setting of concrete, and form removal averaged two weeks' time. To break up the potential monotony of homogenous concrete construction, a number of different home layouts could be achieved by rearranging form panels. Molds for external wall adornments, including friezes and pediments with Arts and Crafts-style ornamentation, could be attached onto selected panels. After the forms were stripped, concrete dressing was applied to the walls to create a smooth exterior and even color.

To expedite construction, foundation holes were blasted out using dynamite in January 1911. Work resumed in April under more favorable weather conditions, and construction of the apartment buildings and detached homes was completed later that year. Notably, only a selection of these first edifices was built to the intended all-concrete construction specifications. All but the four apartment buildings and a single detached home at 612 Polk Street are instead concrete shells with wood frame interiors. It is likely that after discovering just how difficult it was to maintain the horizontal integrity of concrete floor and roof slabs, the single-material design was abandoned for the speed and surety of wood floors and tin roofs. ${ }^{45}$

The concrete homes built for United States Sheet and Tin Plate's Gary mill workers consisted of flats, detached single-family cottages, and terraced row houses. (Figure 2.4) Built according to the "Philadelphia plan" per Creighton, the terrace homes became - and remain - the most iconic figures in Gary's "Edison Concept" development. Laid out in rows of ten attached homes, each house is paired on a common wall along which the floor plan is mirrored. Only one of the terraces is three stories in height; ${ }^{46}$ the remainders are two-story townhouses with two or three bedrooms.

The terrace at 404-22 Polk Street is an excellent example of the most common of the iconic Edison Concept homes. (Figure 2.5) The terrace contained ten two-story rowhouses, with a continuous single-floor, full-width open entry porch spanning the front façade. The face of each individual home was distinguished by the massing of two paired homes in the center and the ends of the terrace, split by individually massed homes.

Square designs cast as coping doubled as downspouts, and concrete buttressing from the second floor to the porch roof marked the boundary between each house. Only the center paired homes' rooflines differed, with a pedimented parapet with stepped coping that is

\footnotetext{
44 "Progress Being Made on Concrete Houses for Steel City," Concrete 10, no. 12 (1910): 65. Torpedo sand is a coarse variety of sand (maximum 3/8" grain) used in concrete and ready-mix.

${ }^{45}$ Christopher Baas, "Concrete in the Steel City: The Edison Concept Houses of Gary, Indiana (Multiple Property Documentation Form)," National Register of Historic Places (U.S. Department of Interior, 2009), 13.

46 336-54 Van Buren Street featured three bedrooms, and were frequently used as boarding houses. All homes are in situ, but unoccupied and in disrepair as of 2013.
} 
reflected in its entry porch. The flat-roofed porches featured an outlined rectangular frieze relief. ${ }^{47}$

Each house was approximately 1,050 square feet, studded with two one-over-one wooden sash windows on each floor's front and rear walls. Roofs were sheathed in tin, likely provided by the corporation, and pierced by concrete double-flue chimneys between each paired house. Each home had its own front and rear entrances. The raised continuous front porch was accessible by concrete walkways and stoops; the evenlyspaced crawlspace vents served as access to each home's basement coal room. The terrace's rear face was massed with five wings that created small courtyards to serve as open, two-story airshafts for each home. The walls of each first-story courtyard contained single one-over-one sashes angled inwards to promote updrafting airflow. The window placement repeats on the flat walls above.

Homes in the 404-22 Polk Street terrace were of the two-bedroom floorplan. The first floor of each house held a living room, dining room, and kitchen. Upstairs consisted of two bedrooms - one at the front of the house, and one at the rear-with a full bathroom, a closet, and small hallway between. All floors were wood, and interior walls and ceilings were plaster over wood lath.

Small details indicate the Arts-and-Crafts influence on the architecture of the terraces. All doors were simple wooden two-panels held in columnar jambs. Wooden mantels top decoratively molded fireplaces, and built-in cabinets grace the kitchen and dining rooms. More functionally, however, a full basement was built for each unit with room for laundry, storage, utilities and coal deliveries.

An accurate count of the total concrete homes built for United States Sheet and Tin Plate in Gary escapes research, as accounts vary from 86 to 110. Taylor cites the following breakdown of homes in 1915:

24 apartments, some of 3 rooms

but mostly of 4 rooms

40 five-room houses

30 six-room houses

10 nine-room houses (3 stories)

6 detached houses. ${ }^{48}$ at $\$ 12.50$ a month

at 16.00 a month

at 17.50 a month

at 20.00 a month

at 27.50 a month

${ }^{47}$ Christopher Baas, "Registration Form for Polk Street Terraces," in National Register of Historic Places (U.S. Department of Interior, 2007), 5.

${ }^{48}$ Taylor, Satellite Cities, 187. 
However, a survey of the 1915 Sanborn Fire Insurance Maps shows 96 houses constructed, including six four-apartment buildings, six detached cottages, and eighty terraces. ${ }^{49}$

The homes were eagerly rented by United States Sheet \& Tin Plate transplants, who appeared happy to find modern homes for reasonable rents near their workplaces. ${ }^{50}$ Among these first residents was English immigrant Samuel Partridge. ${ }^{51}$ Born in Staffordshire in 1854, Samuel had moved to Swansea, Wales by 1881 to work in the region's tin mills. ${ }^{52}$ While employed as a roll turner, he and his wife, Harriet, lived in a narrow two-story rowhouse at 26 Bennett Street, Landore. The layout and environment of the small attached home can be easily construed as a comparable, though earlier, design to that of 404 Polk Street in Gary. However, this townhome, marked by one one-over-one transom window on each floor, was part of an alternating pattern of stucco- and cut fieldstone-faced block of houses. The side-gabled row featured doors with concrete quoined sills, door jambs, and keystone entablatures. The internal floor plan likely consisted of two rooms on each floor, with front and rear hearths for maximum circulation. Small gardens behind the homes allowed for some respite from one of the United Kingdom's busiest metalworking ports. ${ }^{53}$

The Partridges immigrated to the United States in 1887, settling in Vandergrift, Pennsylvania by 1900 . Following the town's establishment as the industrial community for the workers of Apollo Iron and Steel, Samuel resumed his career as a roll turner in the largest sheet mill in his adopted country. The family rented a large front-gabled frame home on Sumner Avenue, one of only 48 company-built homes in Vandergrift. ${ }^{54}$ Despite their construction which contradicted town designer Frederick Law Olmsted's insistence on personalized, aesthetically-pleasing architecture, the homes built by the Vandergrift Land Improvement Company were seen as essential to the town's development. The houses on Sumner, Farragut, and Sherman Avenues featured running water and electricity. Furthermore, geographer Anne E. Mosher argues:

A growing, thriving mill town with a real-estate market could not develop without a rental house market. Given the emphasis that Apollo Iron and Steel had placed on private property ownership, as well as the potential return on rental property, the demand for housing by segments of the population who could not afford to

\footnotetext{
${ }^{49}$ As of 2013, only 76 of these homes remain, including one apartment building, four cottages, and 68 terrace houses (320-322 Monroe Street have been demolished). Of these, nearly sixty percent are recognizably abandoned.

50 Taylor, Satellite Cities, 187.

51 "Sam Partridge," in Fourteenth Census of the United States (1920), Gary Ward 2, Lake Co., Indiana, p. 14B, e.d. 96.

52 "Samuel Partridge," in Census of England and Wales, 1881, Swansea, Glamorgan, Wales, p. 6, e.d. 1.

53 "Industrial Workers' Housing in Wales: Care and Conservation," ed. Cadw: Welsh Historic Monuments (Cardiff: Welsh Assembly Government, 2005).

54 "Samuel Partridge," in Twelfth Census of the United States (1900), Vandergrift Borough, Westmoreland, Pennsylvania, p. 14B, e.d. 0075; "Samuel Partridge," in Thirteenth Census of the United States (1910), Vandergrift Borough Ward 1, Westmoreland, Pennsylvania, p. 5B, e.d. 0209.
} 
own shelter, and the inability of some owners to sell property when they left town, it seems that rental property was an inevitability in Vandergrift. ${ }^{55}$

Following U.S. Steel's acquisition of Apollo Iron and Steel in 1901, the Vandergrift mill became a part of subsidiary American Sheet and Tin Plate Company. Needing seasoned workers to fill their ranks at their new Gary plant in 1911, it is likely that Samuel Partridge's decade of service put him near the top of the list to transfer. City directories for Gary show the Partridge family occupying 404 Polk Street in 1918, with both Samuel and son Arther listed as roll turners for American Sheet and Tin Plate. The family occupied the terrace home through Samuel's retirement in 1920, later moving to a larger frame-and-stucco Foursquare house in closer to the plant. ${ }^{56}$

On the part of U.S. Steel, the building of these concrete homes was never explicitly intended as a philanthropic push to provide a high standard of housing for working class families. Landscape architect Christopher Baas points to the eviction of "Shacktown" residents in preparation for the homes' construction as proof of the corporation's indifference to the struggle of the working man to find adequate housing. ${ }^{57}$ Rather, as with all developments in Gary, it was a matter of dollars and common sense. Few substantial explanations were provided in contemporary literature as to why concrete was only now being utilized in residential construction, despite the proximity of subsidiary Universal Portland Cement's Buffington Harbor plant - at that time, the largest cement plant in the world-being located nearby. Taylor enumerated the direct financial benefits of the undertaking: "from the capitalist's point of view it is urged that a concrete house is a far better investment at 8 per cent than a frame house is at 10 per cent." 58

Initial cost savings in the construction of the concrete homes was based on a number of human and material factors. Lots for the homes were provided by Gary Land Company, who granted the contractors special dispensation to build straddling lot lines. Densely packed terrace homes provided both space and material savings. The corporation had secured rights to use patented form designs from Reichert, but had not contracted with them, preferring to produce the forms themselves. American Sheet and Tin Plate fabricated the forms in their Pittsburgh plant and shipped them via rail to Gary. ${ }^{59}$ Reichert's mold forms had been selected not for their engineering superiority, but for their simplicity in casting and assembly. This in turn allowed fewer and less-skilled workers to be employed in the homes' construction. Taylor offered by way of the following explanation:

\footnotetext{
${ }^{55}$ Mosher, Capital's Utopia, 106-107.

${ }^{56}$ Gary, Indiana City Directory, 1918, 297; "Sam Partridge," U.S. Census, 1920; Gary, Indiana City

Directory (Indianapolis: R.L. Polk \& Co., 1925), 362.

${ }^{57}$ Baas, "Concrete in the Steel City," 260.

58 Taylor, Satellite Cities, 186. This assertion is unsubstantiated.

59 "Progress Being Made on Concrete Houses for Steel City," 64.
} 
Curiously enough the actual decision to use concrete construction came when the sheet and tin plate company's engineer found excessively high building costs at Gary, due to high wage scales established by the building trade unions. It became necessary to devise a construction scheme which, by the use of machinery, would reduce the labor factor to the smallest proportions. ${ }^{60}$

These factors readily demonstrate that U.S. Steel was not interested in constructing the concrete homes for any altruistic, humanist reasons. Nor had they made any overtures that this undertaking indicated anything other than the filling of a need for housing, as summarized in a contemporary Universal Portland Cement Company Monthly Bulletin:

It is in no sense a philanthropic enterprise on the part of the builder, but rather an effort on their part to make homes which will be available for their employees and which will return a reasonable profit on the investment. The agitation in favor of concrete and the numerous experiments throughout the East gave warrant for the trial of concrete in this undertaking. ${ }^{61}$

Viewed through the lens of U.S. Steel, the development of the city of Gary was a success. It had all the physical trappings of a paternalistic company town, as well as the infrastructure of an experiment in social reform, but could not fully claim either of these titles. This city established by fiat was designed simply for the necessity of humanely housing workers, and the financial comfort of the corporation. Furthermore, the hesitating successes of early developments by the Gary Land Company could be celebrated for nearly fulfilling their intended purpose of avoiding all things Pullman-esque: while forced into becoming corporate landlords, U.S. Steel had done so only through a subsidiary, and even then sought to divest itself of homeownership as quickly as possible through the Home Ownership Plan. Additionally, while having planned the municipal utilities' infrastructure, the steel trust was not tasked with providing utility services to citizens. The simple, yet detailed plans that characterized Gary's First Subdivision seemingly trumped the heavy-handed, elaborate scheme that played a role in the demise of Pullman.

As early as 1920, U.S. Steel began touting their "Home Owning Plan" to employees and investors, showing off their successes and "some of the houses built by the Corporation for renting or selling to employees under the provision of the Home Owning Plan" in their Bureau of Safety Sanitation \& Welfare Bulletins. ${ }^{62}$ In the following years' bulletins, the topic took up more and more space as a point of pride, as well as business acumen, for the steel trust. Several homes and their occupants from Gary's iconic First and controversial Ninth Subdivisions took their place in these

\footnotetext{
60 Taylor, Satellite Cities, 186.

61 "Progress In Concrete Home-Building," Universal Portland Cement Co. Monthly Bulletin 90 (1911): 208.

${ }^{62}$ BSSW, "Home Owning Plan," Bulletin 8 (1920): 76-77.
} 
Bulletins, which effectively introduced the fledgling city's de facto residential segregation to employees nationwide.

\section{The “Steel Mill Quarter”: Gary Land Company’s Ninth Subdivision}

From the city's inception, U.S. Steel sought no close relationship with Gary's black community; African-American workers were not hired in steel production jobs, philanthropic requests by black churches were largely ignored, and housing options were limited to exorbitantly-priced privately-owned slum rentals. This changed rapidly during the early years of the Great Migration, which occurred in Gary following two world events: first, in response to the shortage of European immigrants created by World War I, the Russian Revolution, and the Immigration Act of 1917; and second, by the Great Steel Strike of 1919. To fill this widening gap, U.S. Steel began aggressively recruiting southern African-Americans to serve as interim workers and strikebreakers. Nonetheless, despite such contentious beginnings, once in Gary, African-Americans put down roots.

Black migration to Gary was swift, marked by sharp jumps in African-American employment each year. In 1916, African-Americans employed at Gary Works made up only 2.9 percent of the entire labor force. One year later, that number had soared to 7.4 percent. U.S. Steel made a locally unprecedented move in 1917, announcing that Gary Land Company would be building a black-only subdivision centered around Carolina Street south of the Wabash Railroad tracks. Carved out of The Patch, this new neighborhood was the brainchild of Gary Land Company head Horace Norton and a local group of white Protestant clergy dubbed The Calumet Church Foundation who felt it their duty to make racial segregation appealing to both Gary's white and black communities. ${ }^{63}$ U.S. Steel concurred, likely in a thinly-veiled effort to press "the rural southern Negro, with his limited education and the economic and social restrictions placed on him [into] adapting himself to the urban conditions of the northern city." 64

Gary Land Company's Ninth Subdivision was platted on July 20, 1917 with the approval of Captain Norton and Eugene J. Buffington representing Illinois Steel. (see Fig. 2.1) Encompassing twenty-six and one-half acres, the polygonal neighborhood featured fifteen residential blocks and one central park. As in the city's other GLCdeveloped subdivisions, all public utilities were provided, as well as curbs, sidewalks, and macadamized streets. Shortly after the plat filing, construction began on homes lining Virginia, Carolina, and Georgia Streets south of the Wabash right-of-way; East $13^{\text {th }}, 14^{\text {th }}$, and $15^{\text {th }}$ Avenues intersected the streets laterally. The homes constructed here were small stucco bungalows and duplexes, marked by limited design variations and simple adornments. Soon after construction, the deep glacial sand covering the yards of the

${ }^{63}$ Ruth Hutchinson Crocker, Social Work and Social Order: the Settlement Movement in Two Industrial Cities, 1889-1930 (Urbana: University of Illinois Press, 1992), 188-189.

${ }^{64}$ Quillen, "Industrial City: A History of Gary, Indiana to 1929," 418. 
freshly-built homes was concealed with topsoil and seeded with grass, symbolically announcing the neighborhood's permanence. ${ }^{65}$

Despite this rush to establishment, further justification for the Ninth Subdivision was perpetuated by its proponents to silence any lingering detractors. Within Gary's white elite, the ever-present sense of noblesse oblige rationalized this "privilege" granted to the black community. In 1919, a church-sponsored survey of the city's AfricanAmericans declared vice the only consistent influence in the black community, and that the provision of infrastructure would change this by aiding in their moral uplift. Shortly thereafter, an editorial in the Gary Evening Post asserted "Colored people everywhere prefer to live together and this new subdivision ... is going to allow them to live in the same neighborhood decently and well."66

To U.S. Steel, however, the driving motivation to develop a black-only neighborhood was to increase the stability and tenure of their African-American labor force. The nature of employment available to them-strikebreakers and wartime replacements at the lowest skill levels-bore extremely high turnover. During World War I, the average term of employment for an African-American in the steel industry was one month. White industry and community leaders surmised that this was part of the meme of the "shiftless southern negro," who required moral guidance and incentive to commit to their employment and to their employer. However, contemporary labor historians have countered the racist rationale for the segregated subdivision with a narrative of resistance. Instead of shiftlessness, black steelworkers were responding to their limited opportunities for advancement, modern comfort, and social parity by exercising their personal agency in when and where to work. ${ }^{67}$

Upon the groundbreaking of the Ninth Subdivision, resistance became active in Gary's black community. Early on, U.S. Steel sought to curry support for the segregated neighborhood from the city's black churches. Gambling on African-American clergymen serving as informal mouthpieces for the steel trust, several pastors were approached by corporate agents extolling the virtues of moving their churches into the Ninth Subdivision in order to attract the congregation there as well. Gary Land Company and the Calumet Federation of Churches painted a picture of a self-contained black-only neighborhood, benefitting the interests of both the city's black and white communities. However, this plan backfired on the white leaders. Memories were long in Gary's black religious community, and many recalled U.S. Steel's lax support of them up to that point. Others

\footnotetext{
${ }^{65}$ Gary Land Company's Ninth Subdivision [map], 20 July 1917, "Lake County, Indiana Plat Books." Crown Point, IN: Lake County Recorder's Office, book 13, p. 15; "City, Looking N. at Carolina St. from 14th Ave." [photo], 3 June 1918, in U.S. Steel Gary Works Photograph Collection, 1906-1971, IU Digital Library Program, Calumet Regional Archives at Indiana University Northwest.

66 "Need Church, Amusements for Negroes," Gary Daily Tribune, 20 June 1919, 8.

${ }^{67}$ John T. Clark, "The Negro in Steel," Opportunity: Journal of Negro Life, March 1926, 87-88; Herbert G. Gutman, "Work, Culture, and Society in Industrializing America, 1815-1919," American Historical Review 78 (1973).
} 
simply did not wish to inconvenience their congregations by uprooting, and saw no reason to move. ${ }^{68}$

By 1918, accusations of forced ghettoization and racist real estate covenants were met with further platitudes from company officials. Some guessed that the subdivision was built to house skilled African-American steelworkers transferred in from mills around Pittsburgh. Others-largely UNIA members-embraced the opportunity to selfsegregate. Black nationalism found a small, but welcome home in the Ninth Subdivision. Its proximity to black-only schools and parks, as well as its physical separation from Gary's white neighborhoods, provided a community insular enough to define itself with limited outside influence. Soon after, the resistance put up by Gary Works' black employees cooled to begrudging acceptance that their best option for clean, affordable, modern housing was the Ninth Subdivision. The homes were soon filled with the families of unskilled and semi-skilled black workers willing to compromise with the corporation's interests. Home, for many, was on the "wrong" side of the Wabash tracks, surrounding Steel Mill Park. ${ }^{69}$

The housing stock of Gary Land Company's Ninth Subdivision is a direct manifestation of the adaptive and reactionary nature of U.S. Steel's paternalism in Gary. Publicly-declared rationale for segregating the city's burgeoning black community based on commonly-held stereotypes was absorbed by the corporation and digested as a call for moral uplift and mutual appeasement. What developed from the quiet opposition-turnedcompromise from Gary's African-Americans resulted in further parallel, but unequal, outcomes: U.S. Steel enjoyed the outward reinforcement of their paternalistic racial policy implementation, and the black community exercised individual negotiations of their landscape through recontextualization at home. The following two cases present pertinent examples of these efforts. The first, an examination of the John H. Smith home at 1340 Carolina examines the physical trappings of a developing black middle class in Gary. The other shows a neighboring multigenerational family, the Wilsons, occupying half of a Gary Land Company-built duplex while negotiating a broader future through higher education.

\section{Carolina St.}

Built in 1918, this one-story, front-gabled, single-family home was constructed on Block 10, Lot 12 in the flattened dune sands of the Ninth Subdivision. (Figure 2.6)

\footnotetext{
${ }^{68}$ Crocker, Social Work and Social Order, 189.

${ }^{69}$ Dharathula H. Millender, Yesterday in Gary: A Brief History of the Negro in Gary, (Gary, IN: D. Millender, 1967), 29; Quillen, "Industrial City: A History of Gary, Indiana to 1929," 416. Based on census records, there is no proof to support the possibility of the Ninth Subdivision being intended for skilled African-American workers imported from Pittsburgh.
} 
The 3,750 square-foot residential lot was situated on the northwest corner of Carolina and East $14^{\text {th }}$ Streets. The small Craftsman-style bungalow was set back from the curb on a twenty-foot building line. ${ }^{70}$ The house's roof consisted of asphalt shingles affixed to an overhanging deck punctuated by open eaves. These eaves displayed plumb cut rafter tails capped on the front and rear gables by shaped bargeboards. A single-flue brick chimney penetrated the roof line in the rear of the house. The north- and south-facing walls of the home each held three four-over-two double-hung windows of varied sizes, set at graduated heights on masonry sills.

The stylish bungalow faced east toward Steel Mill Park with a small enclosed porch embellished with whitewashed beadboard panels. The beadboard circled the porch in a knee wall beneath a sawtooth window rail, and in a lintel above the half-glass fourpanel front door. Four pairs of two-over-two double-hung sashes ventilated the enclosed porch. Beneath the front-facing pairs, the Smiths added two simple clapboard window boxes, adorned only by the wooden brackets that held them up from the knee wall.

The enclosed entry porch sits beneath its own asphalt hip-on-gable roof, with its ridge in line with that of the main roof. With the addition of a decorative notch in the shaped bargeboards, its eaves matched those of the house. Above the whitewashed architrave, vertical stickwork extended upward into the fascia board. The crawlspace beneath the enclosed porch deck was ventilated by wooden grating flanking the two front stairs. The crawlspace beneath the house was ventilated in a similar fashion, with small open foundation vents placed near the façade.

Common also to the Craftsman-style bungalow of the era is the home's stucco cladding. Stucco became a highly-favored building material throughout the northern and midwestern United States in the early twentieth century, though falling from favor by the mid-1920s. Reflective of the turn of the century popularity of fireproof construction, stucco afforded the aristocratic look of Tudor-style false half-timbering at a far reduced cost. Though stucco was a labor-intensive mix of lime, water, and natural cements, its accessibility boomed in the early 1900s along with the introduction of Portland cement. This new patent cement was more easily sourced, consisting of a mix of lime, calcining agents, aluminum and iron oxides, and common industrial byproducts such as blast furnace slag and mill scale as binders. Portland cement stucco provided a harder, quicker bonding material that required fewer repairs compared to lime stucco, making it more than just a decorative siding option. Rather, now stucco could be used for structural support when spread over metal lath attached to a wood frame. ${ }^{71}$

In Gary, the boom of Portland cement may not have ended with stucco. Instead of wood frames woven with lath, homes such as this in the Ninth Subdivision were likely constructed of concrete blocks. In 1906, U.S. Steel spun the piecemeal cement

\footnotetext{
${ }^{70}$ Paul Wagner. Location Survey, 23 August 1952. in Abstract of Title, 1340 Carolina Street, (1934-1952), East Gary, IN. [U.S. Steel Corporation Collection: Sheet and Tin Mill, Box 3, Calumet Regional Archives at Indiana University Northwest].

${ }^{71}$ Anne E. Grimmer, "The Preservation and Repair of Historic Stucco," Preservation Briefs 22 (1990); McAlester and McAlester, A Field Guide to American Houses, 40.
} 
manufacture occurring at Illinois Steel Company's cement works into a new subsidiary, the Universal Portland Cement Company. New facilities were built outside of Pittsburgh and Gary in order to make use of the limestone dust and slag the steel mills produced in copious quantities. The formation of the company was announced in 1906 along with a plainspoken explanation of the economy of the process:

In the manufacture of this grade of cement, the two raw materials, crushed limestone and chilled blast furnace slag are first dried, then ground together in proper proportions, and burned to a clinker in rotary kilns. This clinker is afterwards finely ground and the resulting product is a true Portland cement. ${ }^{72}$

When at full capacity, the Buffington Harbor, Indiana, plant was capable of producing up to 2.2 million barrels of cement annually. This, combined with a nearly endless supply of crushed slag for aggregate, meant plentiful Portland cement for both stucco and concrete block production.

Based upon the regional overabundance of cement and concrete, as well as the remarkable shape that the structure is in today, it is probable that Ninth Subdivision homes were built of concrete blocks covered in stucco. It is also probable, based on the flattened glacial sand on which the subdivision was built, that it sits on a foundation of concrete monolithic piers sunk to the frost line. The wall structure of 1340 Carolina is flush from roof joint to the ground line, covered in stucco from top to bottom. This is made possible by the slower absorption rate of concrete block combined with the superior rain deflection of stucco. By way of contrast, stucco over wood frame and metal lath subjected to regional summer humidity and winter freezing would likely exhibit vertical cracking and flaking. ${ }^{73}$ The uniformity of the bungalow's façade demonstrates the greater suitability of concrete and stucco construction in Gary.

Despite this uniformity, a number of indicators point to changes in the layout of 1340 Carolina Street. (Figure 2.7) The wood frame enclosed porch was covered with stucco sometime after 1922. Also, the original hip-on-gable porch roof was changed to a front-gable to draw the eye to the new false king post truss embellishing the pediment. While the 1922 photograph shows three double-hung windows on the south wall of the house, contemporary photos reveal four pairs of double-hung windows on the same wall. Additionally, the solitary crawlspace vent near the southeast corner has been replaced by two vented glass brick windows to the southwest. ${ }^{74}$

A 1952 property survey, performed by East Gary registered professional engineer Paul Wagner, indicates that the floor plan of 1340 Carolina included both the front entry porch and a small, half-width rear mud room entry. ${ }^{75}$ The total area of the house given in

\footnotetext{
72 "A New Cement Company," Cement Age 3, no. 1 (1906).

${ }^{73}$ Grimmer, "The Preservation and Repair of Historic Stucco."

${ }^{74}$ Lights could be observed through these basement windows during July and August, 2013.

${ }^{75}$ Location Survey, 23 August 1952 [U.S. Steel Corporation Collection: Sheet and Tin Mill, Box 3, Calumet Regional Archives at Indiana University Northwest].This survey also indicates the presence of a
} 
this report is $1,137.3$ square feet. ${ }^{76}$ This, combined with the presence of new ground-level vents and windows, indicates that not only was the rear of the house added onto between 1922 and 1952, but that a partial basement was dug beneath the addition. Other improvements likely included the remodeling of the enclosed porch, removal of the concrete path leading to the north side of the house, and the addition of the rear mud room. This suggests that the economic station of the early owners was comfortable enough to provide opportunity to renovate and add on to their home.

\section{The John H. Smith Family}

All of these things were apt to have been accomplished by the original owners, John H. and Emma T. Smith. Originally from Arkansas, 47-year-old Smith moved his family into 1340 Carolina Street in $1918 .{ }^{77} \mathrm{He}$ worked as a janitor and general laborer at US Steel Gary Works to support his wife, 38-year-old Emma, and 16-year-old stepdaughter Ella Mae Ross. ${ }^{78}$ Emma, a widowed former schoolteacher from New Madrid, Missouri, followed her new husband to Gary to work as a seamstress in a textile factory. ${ }^{79}$ Her daughter, Ella Mae, matriculated from Gary's colored public schools, and found employment as a stenographer in the office of prominent black lawyer and NAACP-member W.C. Hueston. ${ }^{80}$ By 1930, the family was joined by Emma's mother, 68-year-old Betty Bush. At the height of the Great Depression, the Carolina Street bungalow was over capacity, though three of its four inhabitants were actively employed. ${ }^{81}$

Twenty-one months prior to Black Tuesday, the Smiths made the final payment on their mortage to the Gary Land Company. For the sum of \$3,275, John and Emma had paid off their land and improvements exactly ten years after moving into the house at 1340 Carolina Street. Paying off one's mortgage on time certainly qualifies the homeowners as upstanding middle-class citizens, but the Smiths went beyond that. Later that same year, they purchased three lakefront lots in an unincorporated area of Newaygo County, Michigan, some 65 miles north of Grand Rapids. Established in 1921 on the site

609 square-foot detached wood frame garage facing the alley west of the house in 1952. This was not original to the property, nor present in the 1922 photo. As of 2013, the garage has been removed, though its concrete pad remains.

${ }^{76}$ Current real estate indices indicate the square footage of 1340 Carolina Street as 769 sq. $\mathrm{ft}$. It is possible that this number still reflects the original layout of the home based upon 1918 permits.

${ }^{77}$ Gary, Indiana City Directory, 1918, 340.

78 "John H. Smith," in Fourteenth of the United States (1920), Gary Ward 4, Lake, Indiana, p. 29A, e.d. 106.

79 "Emma T. Ross," in Thirteenth Census of the United States (1910), New Madrid Ward 2, New Madrid, Missouri, p. 17B, e.d. 0113; "Emma T. Smith," in Fifteenth Census of the United States (1930), Gary Ward 4, Lake, Indiana, p. 4B, e.d. 0029.

${ }^{80}$ Gary, Indiana City Directory (1925), 395.

81 "Emma T. Smith," U.S. Census, (1930). 
of a former logging camp, the resort town of Woodland Park catered to black vacationers denied service in popular recreation areas. ${ }^{82}$

Woodland Park was created as a sister resort to successful Idlewild, Michigan, the Jim Crow-era African-American vacation retreat renowned for its famous denizens and prominent position on the "Chitlin' Circuit." Black intelligentsia including NAACP cofounder W.E.B. DuBois and hair products entrepreneur Madame C.J. Walker joined entertainers such as Cab Calloway and Louis Armstrong in the pastoral "Black Eden of Michigan." However, within a few years, the bustling nightlife of this Eden had become too raucous for some. The founders of Idlewild-land investors Marion Auther, Wilbur Lemon, and Alvin Wright - responded by creating a quiet residential resort fifteen miles to the south, where the Midwestern black middle class was welcome to relax away from the disruption of show business. ${ }^{83}$

In the late 1920s, Chicago-based Lemon and Wright began advertising Woodland Park in The Chicago Defender, the most widely circulated black newspaper in America. Color ads proclaimed property available for a five-dollar down payment, and one dollar weekly installments. Excursion busses from Chicago, Detroit, and Cleveland brought potential buyers to visit the resort town. Later, a branch line of the Pere Marquette Railway provided direct service to Woodland Park from Chicago and Gary. Convenient access to the resort, combined with the affordable payment options, made summer home ownership attainable to the urban black working class seeking rest and recreation in an accepting environment. Woodland Park hosted Chautauqua events throughout the 1920s and 1930s sponsored by civil rights activist groups including the Niagara Movement, NAACP and Marcus Garvey's Universal Negro Improvement Association (UNIA). Such varied attractions drew in a cross-section of black urban society, including members of Gary's budding black middle class. The Smiths fit well into this demographic, exhibiting their success through the highly-visible discretionary purchase of three adjacent lakefront lots.

In December 1922, the Smith home in Gary was featured in the United States Steel Corporation Safety, Sanitation and Welfare Bulletin No. 9. Under the page heading "Home Owning Plan," the 1922 photo of 1340 Carolina Street is captioned "John H. Smith (Colored), Janitor, Gary, Indiana." (Figure 2.8) The section describes the options United States Steel offered their employees for purchasing a home built by the company. These options included an installment plan for the purchase of an existing dwelling, an installment plan for a dwelling to be erected by or for the company, and a mortgage plan. The portrait of the Smith household is surrounded by similar profiles of workers' homes nationwide purchased under the United States Steel Home Owning Plan, though Smith's

\footnotetext{
${ }^{82}$ Deed to 1340 Carolina Street for John H. and Emma T. Smith. 26 January 1928, and Warranty Deed To Woodland Park Lots for Emma T. Smith, 3 December 1928, both in Abstract of Title, 1340 Carolina Street, (1934-1952), City of Chicago Trustee [U.S. Steel Corporation Collection: Sheet and Tin Mill, Box 3, Calumet Regional Archives at Indiana University Northwest].

${ }^{83}$ Steven Fredrick Jones, Sr., "Woodland Park: Newaygo County's Hidden Black Gem," Michigan History Magazine 94, no. 2 (2010); Ronald J. Stephens, Idlewild: The Rise, Decline, and Rebirth of a Unique African American Resort Town (Ann Arbor, MI: University of Michigan Press, 2013).
} 
is the only African-American example, or indeed, of any racial minority, reported in any of the U.S. Steel Bulletins. ${ }^{84}$

The reasons for the selection of John H. Smith to represent the African-American buy-in to the United States Steel Home Owning Plan are unknown. However, in spite of only having a sixth-grade education, Smith was a literate, vocal proponent for segregation, which lends credence to the idea that his unusual support of separate facilities for blacks fit nicely with corporate development of a colored neighborhood. In the face of dissention against the Ninth Subdivision by other leaders in Gary's black community, U.S. Steel may well have seen Smith as a symbol of their success in stabilizing the home life of their black workers, and eagerly sought to demonstrate this to their investors. By publishing his name, race, and portrait of his tidy home built by Gary Land Company, they did just that.

The Smith family was likely part of Gary's black elite. In addition to owning their own home and property, their social capital was great. Their high school-educated daughter worked for W.C. Hueston, prominent area lawyer and later commissioner of the National Negro Baseball League. The Smiths were financially comfortable enough to improve their home, adding a partial basement and remodeling their front and rear porches in fine, sturdy fashion. Additionally, they were able to invest in property in a distant, fashionable black resort town populated by the working class and intelligentsia alike. It is likely that their time spent here influenced John H. Smith's involvement in the UNIA. It is also possible that daughter Ella Mae met her future husband, Samuel Curry here, as the Currys were a well-known Chicago-to-Idlewild transplant family. These indicators of the Smiths' accumulation of social capital exemplify the upward mobility of early twentieth century blacks, in this case, fostered by economic and social success in the Gary steel industry.

\section{0-1324 Carolina St.}

Another type of housing built by Gary Land Company in the Ninth Subdivision was the side-by-side duplex. (Figure 2.9) The two-story, shared-wall building accommodated two families who entered through separate entrances. The side-gabled roof was clad in asphalt shingles on an overhanging deck ending in open eaves. Like 1340 Carolina Street, these eaves featured plumb cut rafter tails from rake to rake. The roof was pierced by a slope chimney on the rear pitch and centered dormer on the front. The brick chimney featured a double flue (one for each unit) placed parallel to the lowprofile shed dormer. The dormer was faced with three casement windows placed centrally over the common wall, serving dual decorative and ventilation purposes. This

\footnotetext{
${ }^{84}$ BSSW, "Home Owning Plan," 30. Two African-American employees of U.S. Steel subsidiary Tennessee Coal, Iron and Railroad Company (George Jackson, miner, Muscoda, AL; and Dave Washington, machine runner, Docena, AL) are listed as "occupying," but not owning their company-built homes in BSSW Bulletin 4 (1913).
} 
likely indicates that the attic was shared space for storage, rather than being a divided, livable third floor.

Like its neighbors in the 1300 block of Carolina Street, the duplex was clad in stucco from roof joint to ground line. Positioned on the same sandy ground, the house was probably built on a foundation of concrete monolithic piers vented by small foundation vents near the front façade. This foundation likely supported the same concrete block construction of 1340 Carolina Street, making use of Universal Portland Cement's nearby bounty.

Despite the construction similarities, the duplex design differed sharply from the bungaloid style of 1340 Carolina Street. The two-story duplex homes each mirrored the floor plan and exterior of the other. Window placements were perfectly parallel on either side of the common wall, as well as on opposite exterior walls. Small four-over-one double-hung sashes bookended the common wall on both floors' front and rear walls. On the second floor, single six-over-one double-hung sashes were built into the front and rear walls; two one-over-one double-hung windows were placed in each side wall. On the first floor of each unit, four pairs of six-over-one double-hung sashes were built perpendicular to one another near the front façade corners. One-over-one double-hung windows were placed level with the pairs toward the rear ends of each side wall. All windows were built into brick masonry sills.

The front and rear entrances of 1320 and 1324 Carolina Street mirrored each other as well. Each unit had a separate front entrance through separate front porches. The entrances, quarter-lite single-panel glazed wooden doors, opened onto simple entry porches. Consisting of raised wooden decks and piers on concrete footings, the open porches were shaded by individual shed roofs clad in matching asphalt shingles. The closed eaves of the porch conceal the same plumb cut rafter tails as the main roof. Two wooden stairs provided access to the porch, beneath which the crawl space remained open. A concrete path led from the sidewalk to each door, and encircled the building to provide access to the rear. The rear entrances shared an enclosed half-width, hip-roofed porch.

Current evidence suggests Gary Land Company built six of the stucco duplexes in the Ninth Subdivision. ${ }^{85}$ Three of the six, including 1320-24 Carolina St., feature the shed-roofed dormer centered in the front roof pitch. ${ }^{86}$ (Figure 2.10) The other three vary from the duplex design in two ways: the roof design, and the porch enclosure. They feature a hipped roof with a non-ventilated centered gable, and a single enclosed frame porch for both units' front entrances. The porch sits atop a poured concrete foundation, clad in clapboard siding, beneath a connected dual front-gabled asphalt shingle roof. The relative sophistication of this duplex design compared to its side-gabled counterpart, combined with its absence in historic photographs, suggest that it was built later than the Ninth Subdivision's 1918 inception.

85 1404-08 Carolina St., 1425-27 Carolina St., 729-33 E. $14^{\text {th }}$ Ave.

86 701-05 E. $14^{\text {th }}$ Ave., and $1325-27$ Georgia St. 
Many of these stucco duplexes are still occupied today. A recent rental classified for 701 East $14^{\text {th }}$ Avenue advertises two large bedrooms, a full bathroom, hardwood floors, kitchen, parlor inside the front entrance, and stairs to the second floor along the common wall. Like many homes in the Ninth Subdivision, a cement block detached garage has been added to the property. The current landlord asks $\$ 600$ per month in rent, well above the modern value of the $\$ 15.00$ Gary Land Company asked of tenant Kannie E. Brundidge in $1930 .{ }^{87}$

The duplex at 1320-24 Carolina Street is no longer occupied, its windows boarded up with plywood. (Figure 2.11) However, several changes have been made to its exterior since its last historic portrait in 1922. Its open front entry porches were enclosed under a multilevel shed roof. The enclosure was clad in aluminum siding, and set on a poured concrete foundation with similarly appointed masonry stairs leading to the front doors. Like 1340 Carolina Street, a partial basement was added beneath 1320, as evidenced by ground-level windows and basement entrance dug into the north end of the property to access a door set in the former location of the building's crawlspace vent. Additionally, the shared rear hip-roofed porch was extended outward on 1324 with the addition of a frame shed-roof porch punctuated by a front-gabled rear entry porch in its center.

The duplex had several occupants since its construction in 1918. The first residents to own one of the units was 31 year-old steel mill laborer John Wilson in 1940. John and wife Anna purchased the house for \$1400 with John's \$1200 annual income. Born into sharecropping, John moved from Hamilton, Mississippi by way of Arkansas with his parents and five siblings to Gary by 1930. Here, his father, Claude, found work as a laborer at Gary Works, and the family rented a home on Virginia Street near to that of noted lawyer and Smith family associate W.C. Hueston. By 1940, Claude had died, leaving wife Malisa and three children still at home. Based on the 1940 census, one can posit that the widow and her family moved into 1324 Carolina Street with John and Anna so that the remaining children could continue their schooling. Willie, the youngest, had completed his first year of high school. Daughter, Minnie, 19, had attended three years of college, and son William, 20, four years. The purchase of the home, combined with the Wilson family's pursuit of higher education in a time when it was not readily available to the black working class again supports a hypothesis of the formation of a black middle class within the setting of Gary Land Company's Ninth Subdivision. ${ }^{88}$

Social reform in housing Gary residents proved to be more than an attractive buzzword that garnered praise for concrete utopianism in the First Subdivision. On the "wrong side" of the Wabash tracks, social reform found a home in the class aspirations of the Ninth Subdivision. Although not initially well-received by the city's black

\footnotetext{
87"Kannie E. Brundidge," in Fifteenth Census of the United States (1930), Gary Ward 4, Lake, Indiana, p. 5B, e.d. 0029. Adjusted for inflation, Brundidge was paying \$209.24 in 2013 dollars, whereas the modern tenant would be paying \$43.01 in 1930 dollars ("Consumer Price Index Inflation Calculator," http://data.bls.gov/cgi-bin/cpicalc.pl).

88 "Claud Wilson." In Thirteenth Census of the United States (1910), Hamilton Beat 3, Monroe, Mississippi, p. 11B, e.d. 0064; "Kannie E. Brundidge," U.S. Census (1930); "John Wilson," in Sixteenth Census of the United States (1940), Gary Ward 4, Lake, Indiana, p. 1A, e.d. 95-41.
} 
community, eventually the black-only Gary Land Company addition became a bastion of house-proud African-American steelworkers and families with long housing tenures and ownerships - some of which endure today through familial connections. Additionally, for U.S. Steel, it provided a prototype of sorts for later black-only company towns in the industrial north, such as the Lincoln Way section of the Wilson town site adjacent to the Clairton By-Product Coke Plant. ${ }^{89}$ Through this, the corporation influenced segregated interpretations of the "American Dream" by cultivating racial dualism through physical separation.

The sense of pride in ownership and place fostered the establishment of a black middle class in Gary, or at least the trappings thereof. This is evident in the higher education of John Wilson's siblings, at a time when this was difficult to accomplish as an African-American in any city, much less Gary, Indiana. But it is most visible in Emma R. Smith's purchase of vacation land in the black resort town of Woodland Park, Michigan. Without the senses of pride in place and black community cultivated within the Ninth Subdivision, Smith may not have had the cultural or financial opportunity to obtain such a symbol of social mobility. In a city in which no one was truly a native son, these elements created invaluable social capital.

${ }^{89}$ BSSW, "House Development at Wilson Station, PA. for the By-Product Coke Plant," Bulletin 7 (1918): 90-94. 

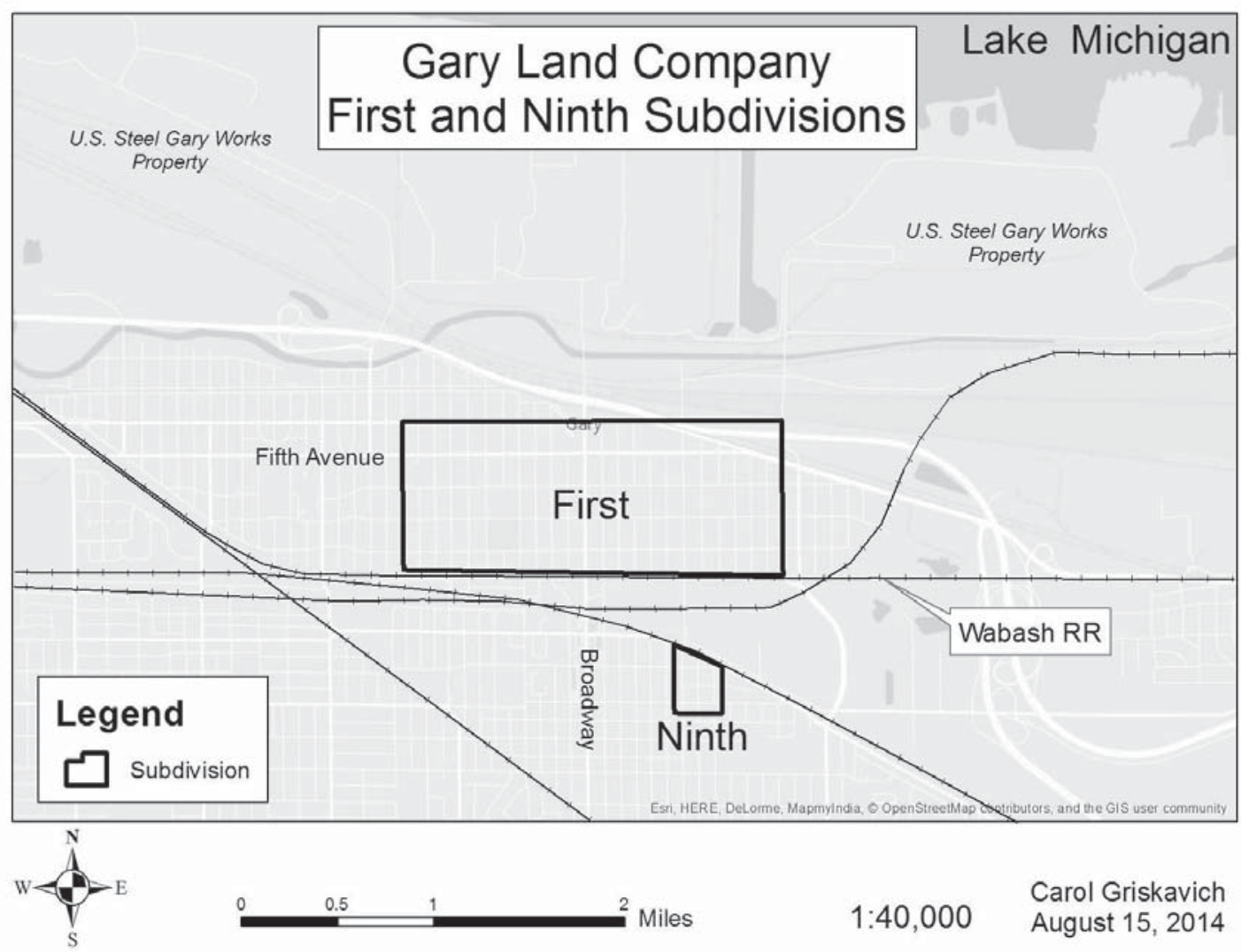

Figure 2.1 Placement of Gary Land Company's First and Ninth Subdivisions in relation to the mill and railroad corridors. 


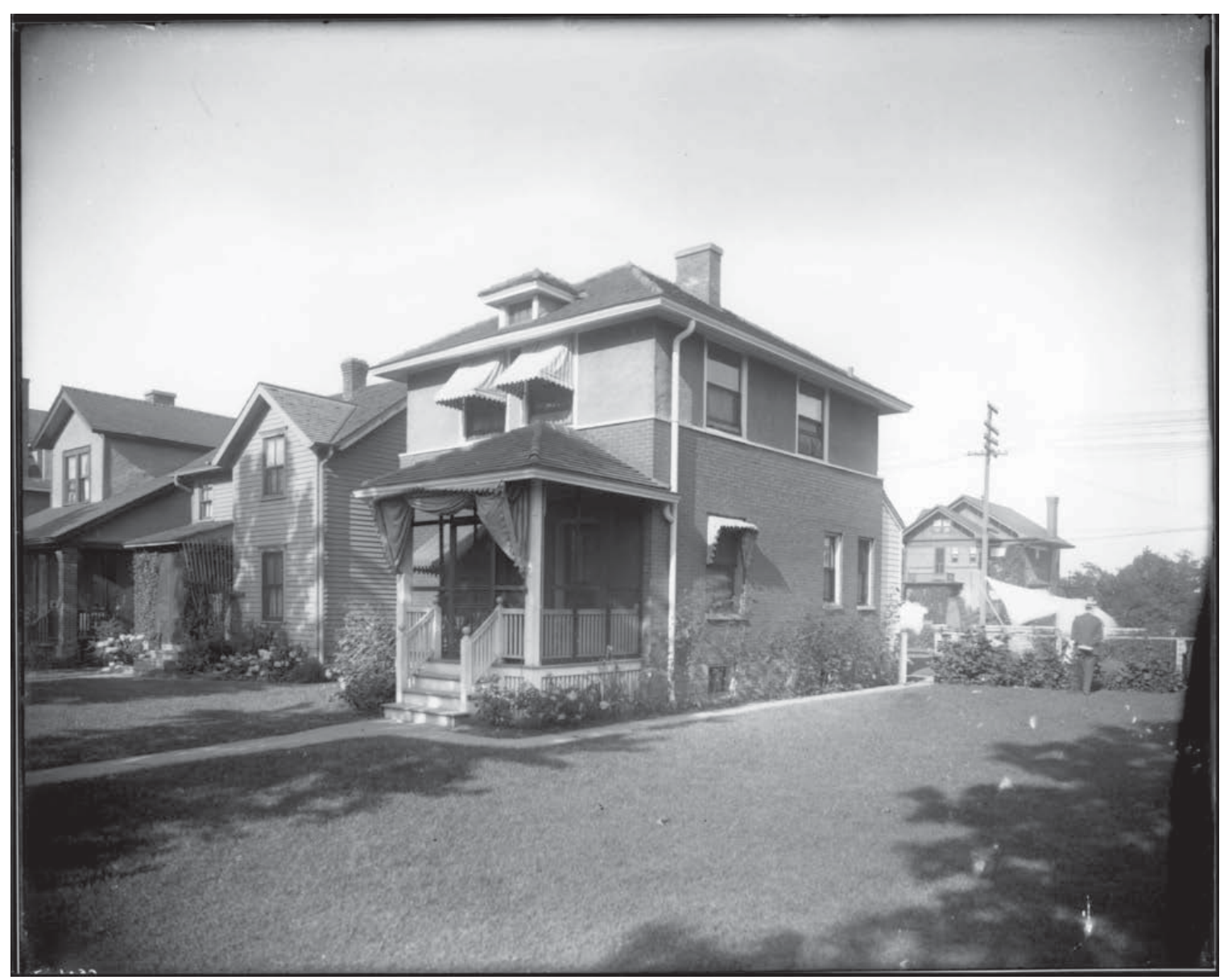

Figure 2.2 735 Van Buren Street, the Walter Sullivan household, 1915. Courtesy of Calumet Regional Archives, Indiana University Northwest. 


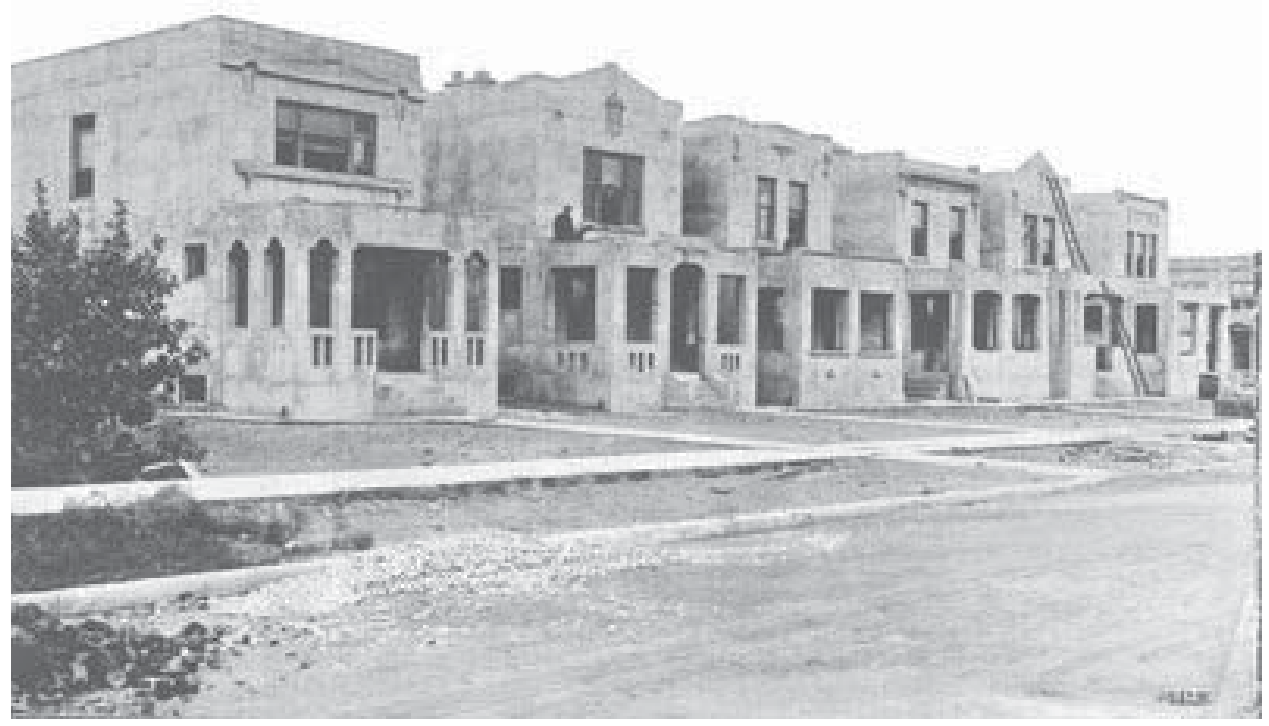

Figure 2.3 The Edison Concept concrete single-family homes under construction on Polk Street, 1912. Courtesy of Metal Forms Corporation. 


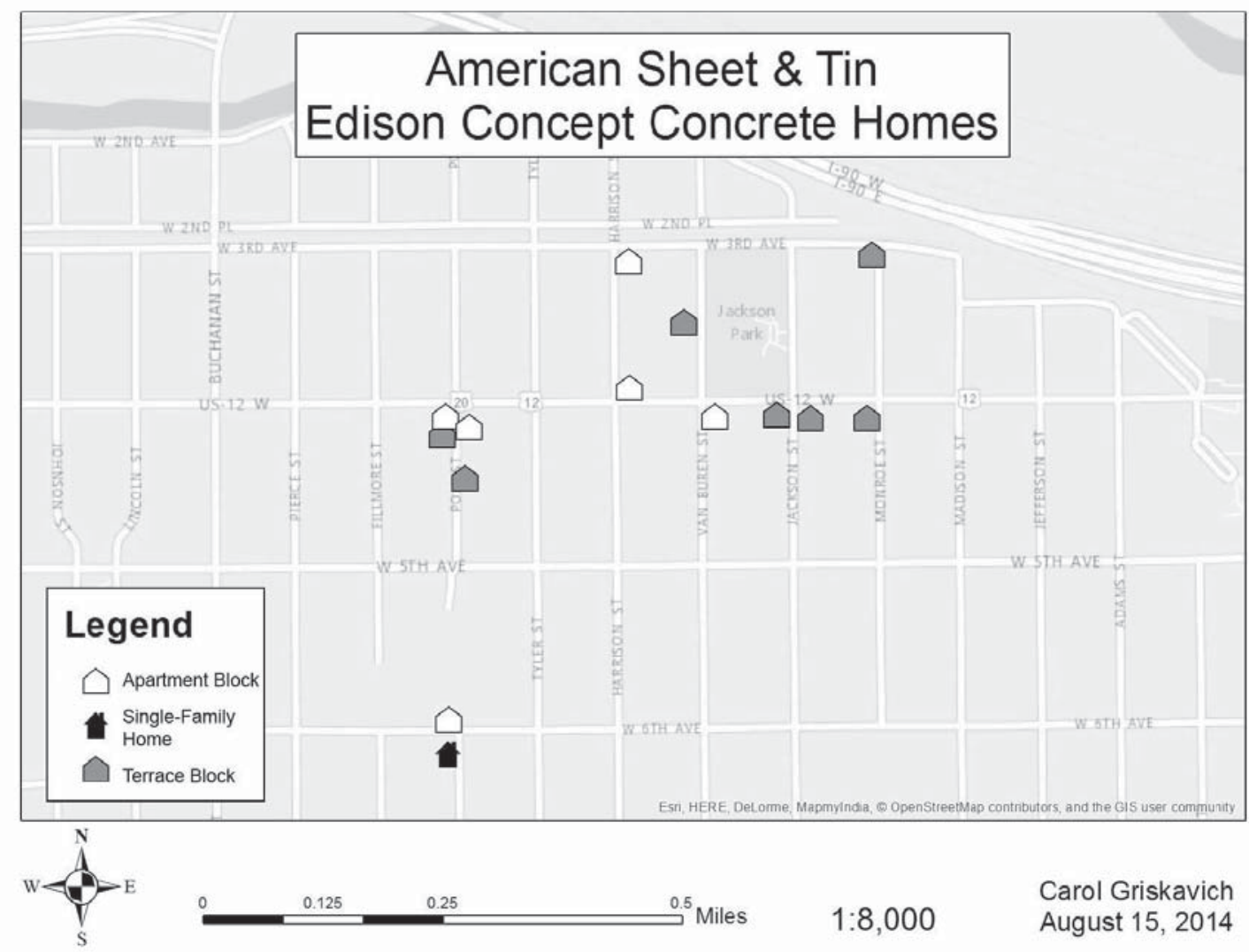

Figure 2.4 Locations of the Edison Concept concrete homes in Gary Land Company's First Subdivision. 


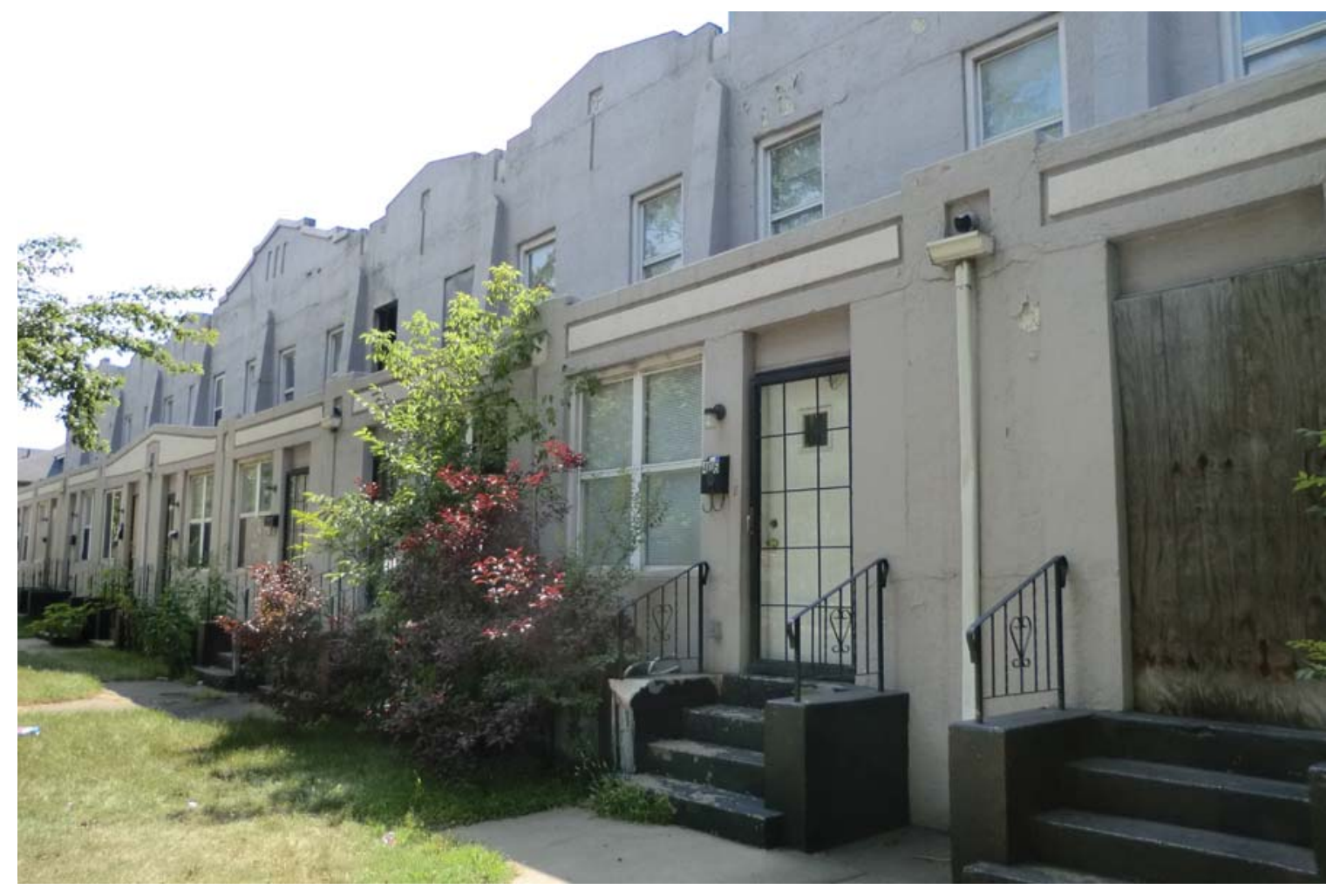

Figure 2.5 Polk Street Terraces, 400-422 Polk Street, 2013. Photo by author 


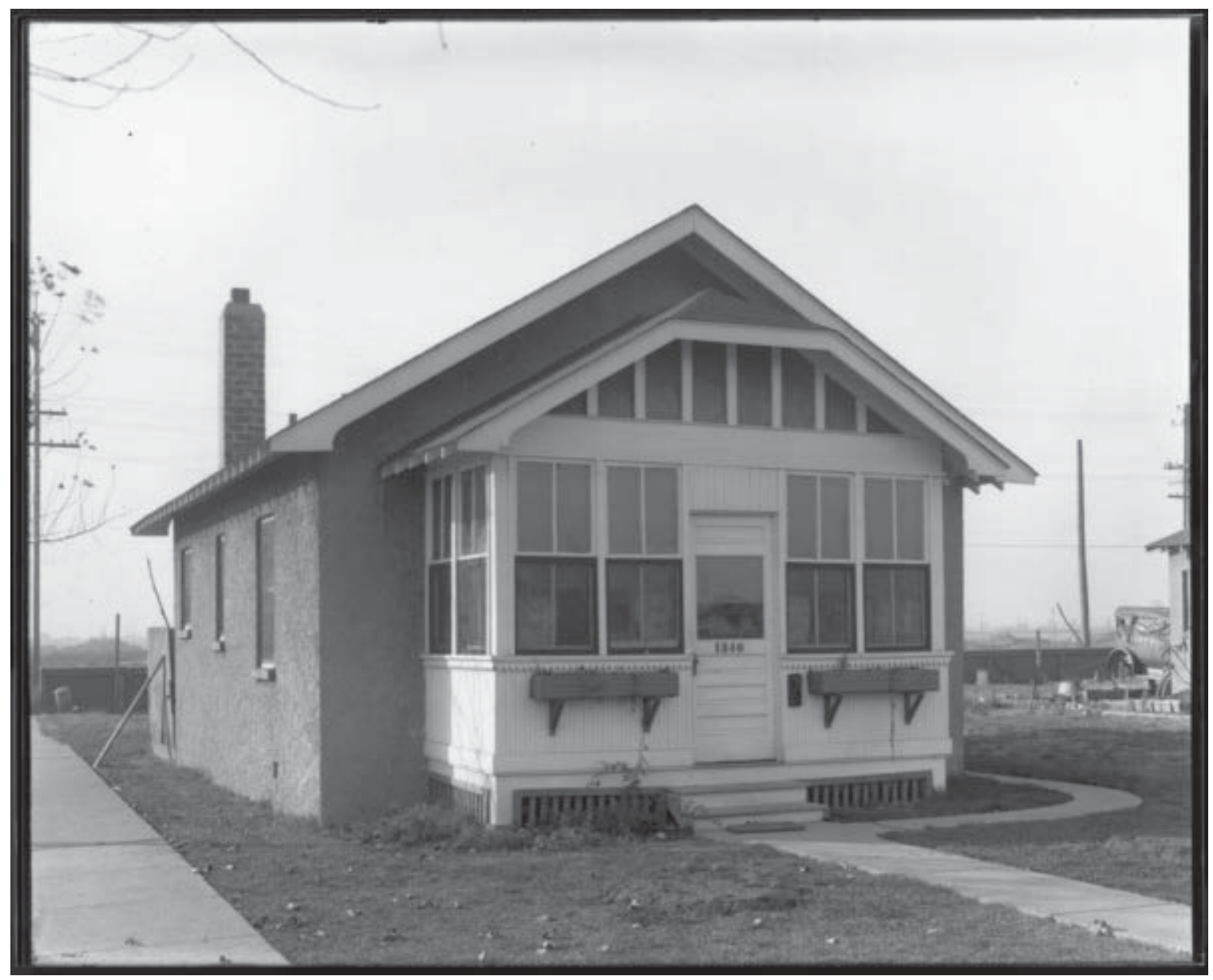

Figure 2.6 1340 Carolina Street, the John H. Smith household, 1922. Courtesy of Calumet Regional Archives, Indiana University Northwest. 


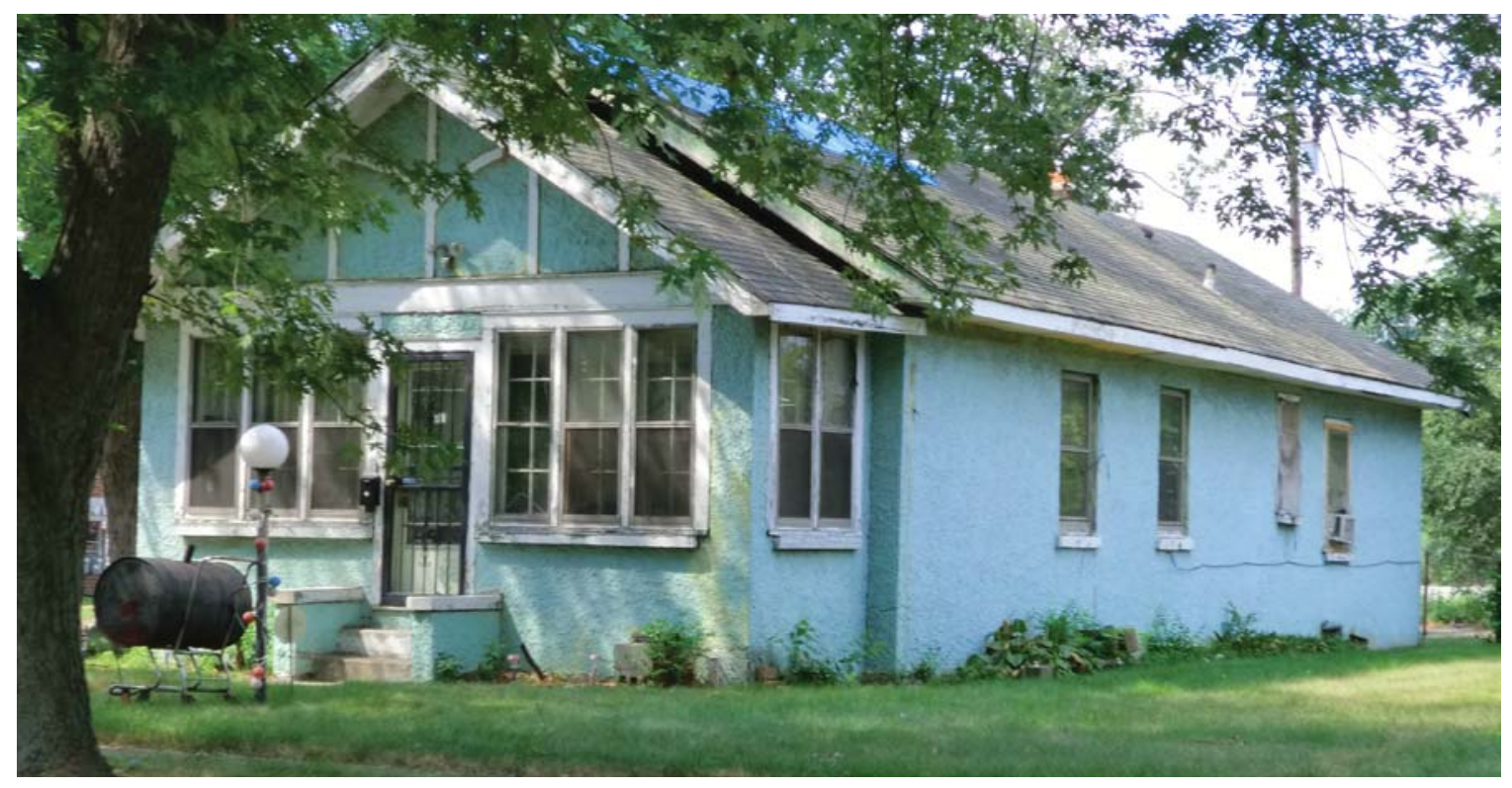

Figure 2.7 1340 Carolina Street, 2013. Photo by author. 


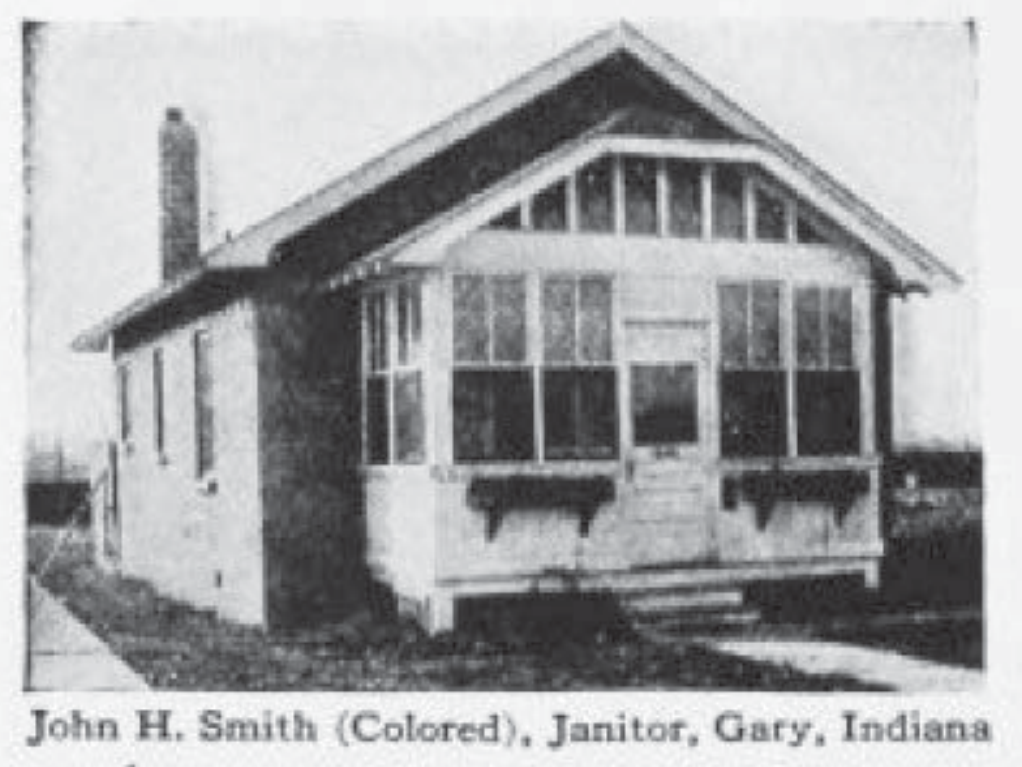

Figure 2.8 1340 Carolina Street appearing in the "Home Owning Plan" section of BSSW, Bulletin no. 9, 1922, p. 30. The photo caption reads “John H. Smith (Colored), Janitor, Gary, Indiana." 


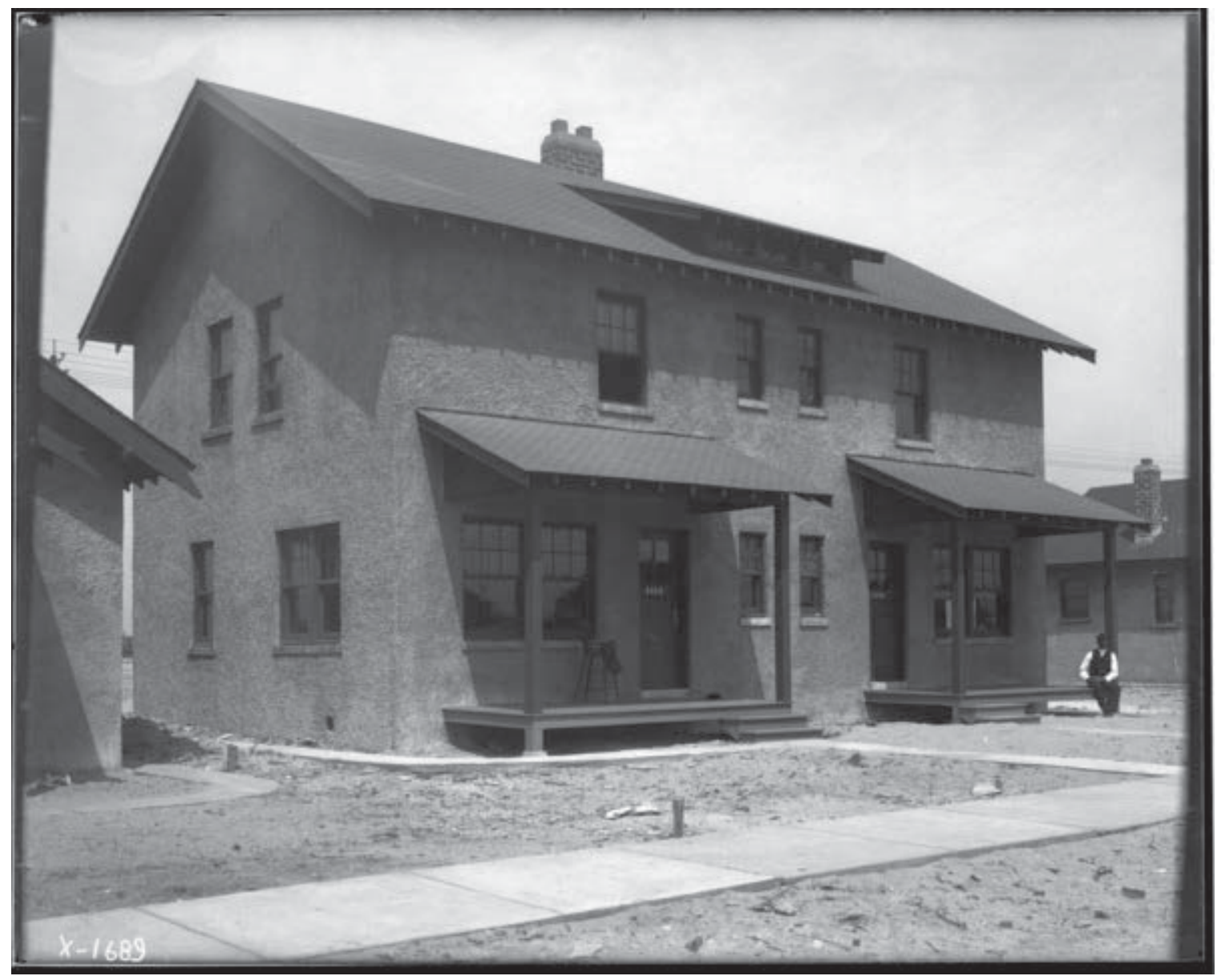

Figure 2.9 1320-24 Carolina Street shortly after construction, 1918. Courtesy of Calumet Regional Archives, Indiana University Northwest. 


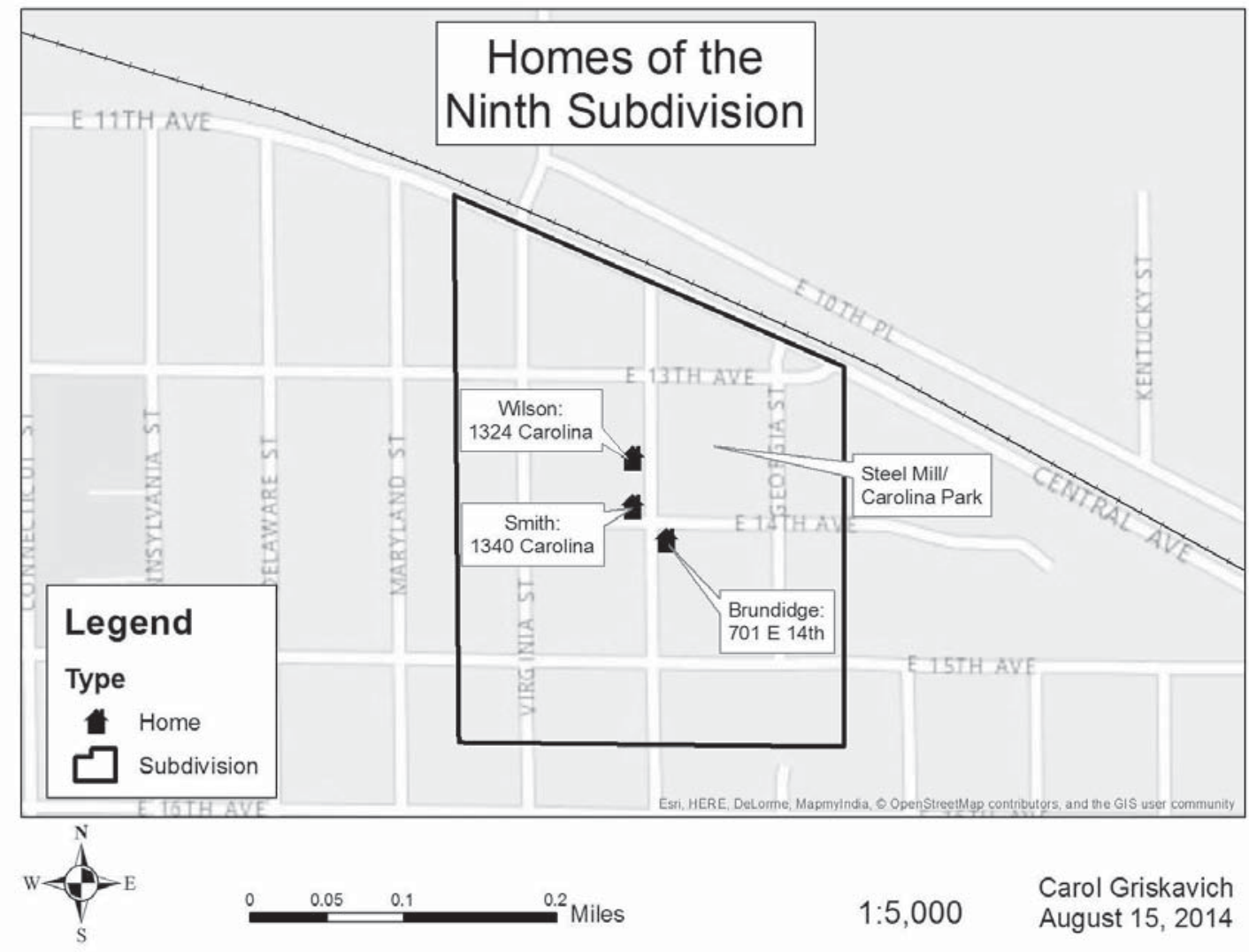

Figure 2.10 Placement of Gary Land Company's Ninth Subdivision. 


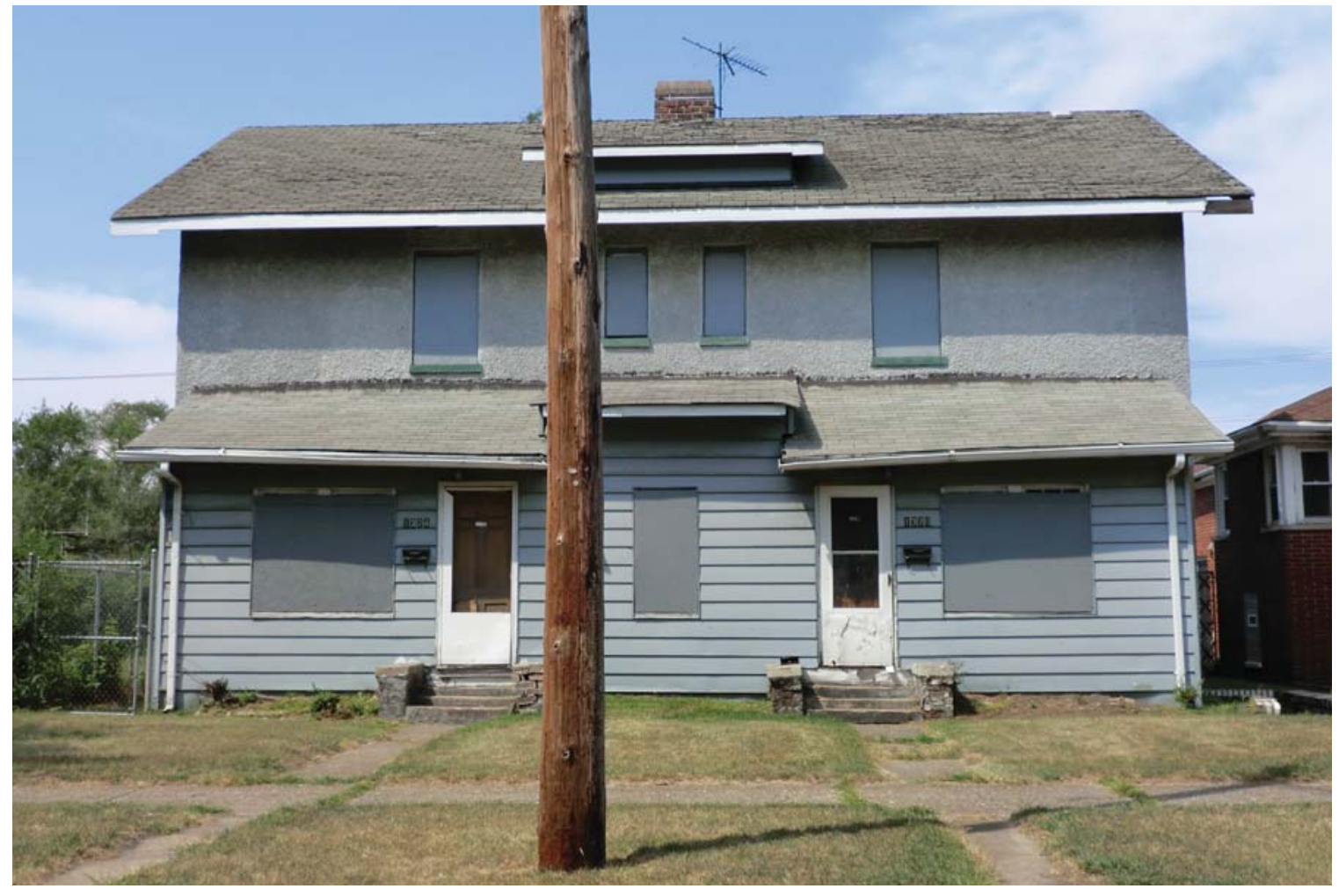

Figure 2.11 1320-24 Carolina Street, 2013. Photo by author. 
"A child," says William Wirt, "is a bundle of twist, wriggle, and squirm. Put a child in a day-long atmosphere of repression and he gets in an antagonistic attitude toward his teacher. Therefore, let's go! Let's not use the school auditorium for a few minutes in the morning for routine 'opening exercises' attended by the whole school, but let's use it every hour of the day." 1

\section{Chapter 3: Education for All, Education for Life}

Nearly a decade before her arrival to Gary, Emma Smith was a young widow living in New Madrid, Missouri. Emma Ross, as she was known then, was raising her 7year-old daughter Ella Mae on the same block as the city's negro schoolhouse, O'Bannon School. A trained teacher, Ross was likely employed instructing the children of the Kentucky Bend settlement's black farm hands, washerwomen, and day laborers. In the mid-1910s, Emma Ross became Mrs. John H. Smith, and joined the influx of AfricanAmericans leaving the agrarian poverty and Jim Crow-era oppression of the South for lucrative industrial positions left unoccupied by the World War I-era stemming of European emigration. ${ }^{2}$

In Gary, Mrs. Smith would have found an educational system far different from home, and far different than that of other industrial communities. Nearly a century earlier, waves of farm girls enticed by high wages and higher morals moved to Lowell, Massachusetts to work in the city's booming textile mills. Many of these girls came from rural areas where opportunities for formal education were scarce. In Lowell, they found a number of company-sponsored (and enforced) prospects for learning. These began in 1825 , with the opening of a corporate-sponsored lending library. Soon after, the Merrimack Company aided in the establishment of the Lowell Lyceum, which featured twenty-five lectures each season given by visiting intelligentsia including Edgar Allen Poe and Ralph Waldo Emerson: The price of fifty cents was eagerly paid, and the halls were packed. Night schools were formed by mill employees and management, and attendance was required of younger workers three months out of each year. Music, language, and art classes were popular, and, under the mill owners' encouragement, the "mill girls" published the popular magazine, The Lowell Offering, from 1840 through $1845 .^{3}$

These opportunities, though hard-won, were often difficult to maintain. Girls found it nearly impossible to stay awake for lessons after ten to fourteen hours working

\footnotetext{
${ }^{1}$ James O'Donnell Bennett, "Gary School System One of Nation's Finest: Credit Belongs to Supt. William A. Wirt," Chicago Daily Tribune, 9 December 1929, 12.

2 "Emma Ross," in Thirteenth Census of the United States (1910). New Madrid Ward 2, New Madrid, Missouri, p. 17B, e.d. 0113; New Madrid, New Madrid County, Missouri [map]. June 1919. "Sanborn Fire Insurance Maps." New York: Sanborn Map Company, sheet 3.

${ }^{3}$ Chang-Shin Lee, "Spin Sisters: Works and Lives of "Lowell Girls" in Early $19^{\text {th }}$ Century America," Journal of British \& American Studies 16 (2007); Doug Stewart, "Proud to Be a Mill Girl " American Heritage 62, no. 1 (2012): 149-150.
} 
on a loom. They attempted to organize their workplaces on multiple occasions, in part to win the right to exercise the intellectual improvement for which many had come to the city. The following decades saw several rounds of wildcat strikes at the Lowell mills, which proved to be a less desirable — and profitable_expression of worker's dissatisfaction for corporation heads.

The final two decades of the nineteenth century saw a staggering 23,000 labor strikes involving more than 117,000 companies nationwide. One option for affected executives was the use of force, as seen in the Pullman Strike of 1894. The general strike was met with federal intervention, scab labor, troop encampments, and fatal violence. The aftermath highlighted not only inherent flaws in the structure of American wage labor, but the loss of millions of dollars in potential revenue for the Pullman Company. In the wake of such conflicts, business leaders recognized that not only did peak production require satisfied, healthy workers, but also limited governmental interference. From these realizations, the Progressive Era was born. ${ }^{4}$

The reformationist spirit of the era encouraged a new form of industrial paternalism termed "welfare capitalism." Executives nationwide realized that in order to resist unionization within individual corporations, more than the basic needs of the worker needed to be met. A fair wage, healthy housing and environment, and proper civic amenities were deemed necessary to remain benevolent in the eyes of potential unionizers. However, to obtain the types of employees that they desired, many corporation heads believed they must cultivate their own. The key to this was education. Providing learning opportunities provided a more stable, socially homogenous workforce with skills suited to modern industries and urban living. These beliefs gave rise to the Platoon System of schooling, the laboratory of which was Gary, Indiana, under the guiding hand of U.S. Steel.

The Platoon System-interchangeably referred to as the "Gary Plan" and "WorkStudy-Play"- emerged from the Progressive Era's combined drive for more widelyavailable public education and emphasis on efficiency. The program focused on total use of school facilities inside and out at all times, public availability of education and related resources, and self-directed learning that encompassed all aspects of modern life. Students in a Platoon school were pioneers in cross-grade departmentalized education, being taught by specialists in traditional academic subjects as well as manual arts and trades. They were also encouraged to teach one another, and to indoctrinate foreign-born students in the modern American way of life. Gradual addition of responsibilities in the Platoon System led to an almost complete student-run and student-supported school, harkening to the good morals and Calvinistic work ethic of rural, agrarian society desired by contemporary American corporations in their urban industrial communities. The translator of these social mores was farm boy-turned-educator William A. Wirt, creator of the Platoon System.

\footnotetext{
${ }^{4}$ Stuart D. Brandes, American Welfare Capitalism: 1880-1940, (Chicago: University of Chicago Press, 1970), 1-9.
} 


\section{William A. Wirt}

In 1874, William Albert Wirt was born to a farm family in Markle, Indiana, a rural village 150 miles southeast of Gary. (Figure 3.1) In addition to his responsibilities on the family farm, Wirt diligently attended the local grade school. He later complained that the curriculum at his local country school was basic at best, however conceding that, "to live so close to Nature that you were unconscious of her had some advantages. Besides I had my father and mother as teachers in Nature and in the practical arts." 5 Through these observations, Wirt developed his first predilections toward the educational theories that would later become the hallmark of the philosopher of education, John Dewey.

In the absence of a town high school, Wirt enrolled at Bluffton High School, nearly fifteen miles southeast of his family farm. In 1892, Wirt received his diploma and entered DePauw University in Greencastle, Indiana. An occasional student, he took two years off starting in 1899 to serve as high school principal and later, superintendent of schools in Redkey, Indiana, near his alma mater in Bluffton. Wirt's early experience with traditional rural schooling here was augmented by summer courses at University of Chicago. Here he had firsthand opportunities to observe the function of play amongst children using the public playground at Jane Addams' Hull House, the machinations behind Arts and Crafts movement founder William Morris' ideas of the dignity of work, and the pedagogical beliefs of educational reformer John Dewey.

\section{Deweyan Education}

In 1894, John Dewey joined the faculty of the newly-founded University of Chicago. While there, he developed his theories on pragmatism and rational empiricism, focusing on a feedback loop of reason and experience to trace the practical consequences of a hypothesis. ${ }^{6}$ Dewey's views on progressive education gave rise to the still-popular University of Chicago Laboratory Schools, opened in 1896. Here, he implemented his belief that learning was an entirely social process, not dissimilar to life itself. Dewey designed the Lab School's curriculum as an extension of the students' home life, rooting lessons in practical household activities such as cooking and handicrafts. The experiential-based learning implemented at the Lab School included field trips to farms and markets to learn about food supply chains, culminating in the students recreating these chains within the school.

After two years of Lab School operation, Dewey established four tenets of pragmatic pedagogy that remain adaptively used to this day. First, students learn via

\footnotetext{
${ }^{5}$ Ronald D. Cohen, Children of the Mill: Schooling and Society in Gary, Indiana, 1906-1960 (New York: RoutledgeFalmer, 2002), 1.

${ }^{6}$ Christopher Hookway, The Stanford Encyclopedia of Philosophy, s.v. "Pragmatism," 2013, http://plato.stanford.edu/entries/pragmatism/; Peter Markie, ibid., s.v. "Rationalism vs. Empiricism," http://plato.stanford.edu/entries/rationalism-empiricism/.
} 
experimentation, which inspires them to gather more information on subjects that hold their interest. Second, pupils aid one another's learning as part of a social cohort.

Additionally, individuals should be challenged to find creative solutions to problems set before them. However, most importantly, the child and their individual strengths - not the lesson itself - must be the center of the teacher's attention from start to finish. ${ }^{7}$

Dewey took cues from the social network of rural communities, and began to conceive of schools as their own small communities. He explained that rural communities were especially effective at teaching children the "habits of order and industry"industry in the sense of hard steady work, not production and commerce-and that constant academic drilling stunted their emotional and intellectual growth. This fit well with Wirt's personal and professional experience in rural education, which he continued to exercise in his hometown. The challenge, however, would later be how to instill small-town values in education into increasingly dense, diverse, and industrial urban settings. This was the challenge Dewey worked on in Chicago and with which Wirt would be faced in the company town of Gary.

Wirt's progressive pedagogy and educational experiences found an ally in Dewey's theories. Upon his return to Redkey, he instituted a number of creative and practical courses including drama, natural science, calisthenics, and medical inspection. Additionally, Wirt opened the town's first public library inside the school. Renewed in his dedication, he re-enrolled in his studies at DePauw, completing his Bachelor's degree and one year of graduate work. While back at DePauw, Wirt observed the differences between him and his urban contemporaries curiously:

I could not help but become interested in understanding the why of the city boy's view of life. I finally saw that the principal occupation of these lads was to kill time, and that killing time was about all they ever had done in life. It was apparent that the lack of taste for worth while $[\mathrm{sic}]$ things was the reason why the average college boy could not use his leisure time profitably. He had never had any training in developing skill as well as appreciation in art, music, dramatics, literature, nature, wholesome sports, outdoor recreation, [or] current events. Besides he had never worked. ${ }^{8}$

Wirt's emphasis on the value of work, time management, and an altruistic desire for selfimprovement would continue to color his pedagogy as it spread to Gary, and beyond.

\footnotetext{
${ }^{7}$ William Harms and Ida DePencier, Experiencing Education: 100 Years of Learning at the University of Chicago Laboratory Schools (Chicago, IL: University of Chicago Laboratory Schools, 1996).

${ }^{8}$ Cohen, Children of the Mill, 2.
} 


\section{Arts and Crafts Movement Influence}

This concern for finding worth and developing skill lends credence to the alternate narrative of Wirt's pedagogical development proposed by educational historian Walter H. Drost, who pointed out that while Wirt attended University of Chicago when Dewey was serving on the School of Education faculty, Wirt was merely enrolled in Sanskrit language courses, so they would not have had any reason to meet. Their connection came later and in another direction than is usually assumed: rather than Wirt sitting at the feet of the master, instead it was Dewey who developed an admiration for Wirt's implementation of the Platoon System. Drost suggests that Wirt's instruction style is derived from his contact with the Arts and Crafts movement. While studying at DePauw University, Wirt was introduced to William Morris's News From Nowhere (1890), a work of utopian socialist science fiction that advocates for a society ruled only by man's appreciation of nature. This admiration, rooted in a non-industrialized agrarian society, translated into a natural enjoyment of creativity and hard work. ${ }^{9}$

Morris' belief that the industrialization of nineteenth century England was dehumanizing to its workers influenced American philosopher Elbert Hubbard. Acting as Morris' "American interpreter," Hubbard attracted a large Midwestern middle-class following through his journal, The Philistine, which spread the gospel of living simply and earnestly while adhering to a nearly Calvinist work ethic. ${ }^{10}$ In 1895 , Hubbard established the Arts and Crafts movement reformist community of "Roycroft" in East Aurora, New York. The settlement was populated by craft guild members specializing in printing, binding, metalsmithing, carpentry, leatherworking, and furniture building. Adherents to Hubbard's ideologies flocked to the community to attend his seminars and witness the craftsmen's expertise for themselves.

In the fall of 1899, Wirt accepted the position of school superintendent of the Bluffton district, his alma mater. According to Drost, it was during this time that Wirt became one of the thousands who eagerly visited Roycroft to learn about their lifestyle and work. He returned to Bluffton laden with samples of Roycroft products, displaying them in the district's high school. The interest generated by the exhibition aided Wirt in adapting Hubbard's manual training programs in Bluffton.

Wirt converted the basement of small Bluffton High School into craft workshops for ceramics, carpentry, and metalworking. ${ }^{11}$ Additionally, he set to work diversifying the curriculum with practical and creative offerings, adjusting the schedule so that students could choose which three of the four yearly terms they would attend (to accommodate both town and farm family schedules), and updating the aging school facilities with indoor plumbing, decoration, and commodious learning spaces. Over the next seven

\footnotetext{
${ }^{9}$ Walter H. Drost, "Social Efficiency Reexamined: The Dewey-Snedden Controversy," Curriculum Inquiry 7, no. 1 (1977): 26-27.

${ }^{10}$ It comes as no surprise that Western industrialists were also fans of Morris' and Hubbard's philosophies, and promoted their tenets of hard work and self-reliance to their employees. However, there is no evidence of U.S. Steel having any direct connections to Hubbard or the Roycroft Movement.

${ }^{11}$ Cohen, Children of the Mill, 3-4.
} 
years, Wirt related to John Dewey by implementing a curriculum that correlated skills learned in manual classes to lessons in parallel academic coursework. For example, boys who were enrolled in pottery classes created clay contour maps for geography courses. Girls who were learning to cook in culinary arts courses prepared and served school lunches. Students of all ages were set to work in construction and maintenance around the school after periods of apprenticeship. Student workers began "first as observers, then as helpers, and finally as workers capable of doing the entire job and teaching it to others." 12 Through this early iteration of what would become known as the "Gary Plan," Wirt's students learned and worked simultaneously in ways that benefited both themselves and their institution.

In his 1906 annual report to the Indiana Superintendent of Schools, Wirt argued that this integrated format of schooling was essential to the holistic development of children:

The harmonious working together of culture and industrial work in the school will be the surest preparation for the continuation of the right education of the child when he leaves the school... It is not our purpose to make carpenters or cooks, but men and women. ${ }^{13}$

Wirt's dedication to both students' intellectual and creative development, and striking a balance between them, piqued the interest of those looking to make progressive social changes from root to tip.

The same year that he promoted the practical education of Bluffton's children as key to their holistic development as adults, an opportunity to form a new school system in a made-to-order city presented itself on the dunes of Indiana's Lake Michigan shoreline. In late 1906, Wirt made contact with Thomas Knotts, the newly appointed Gary Town Board president. ${ }^{14}$ Allegedly, Knotts encountered Wirt while both men were taking a Sunday morning's stroll through the sand dunes slated to be flattened for the grading of Broadway. While discussing their mutual histories as schoolteachers, Knotts became so impressed by Wirt's pedagogical knowledge that he asked the visitor to consider heading the young city's school system. ${ }^{15}$ Though the first school bells rang in Gary in October 1906, Knotts courted Wirt with a signing bonus of $\$ 2,500$ and a contract promising increases commensurate with student population growth. Attracted by the opportunity to

\footnotetext{
12 Drost, "Social Efficiency Reexamined," 27.

${ }^{13}$ William A. Wirt, "Industrial Work in Public Schools," The Twenty-third Biennial Report of the State Superintendent of Public Instruction (1906): 377-428.

14 Thomas Knotts, brother of Armanis F. Knotts, the Hammond attorney who assisted U.S. Steel in anonymously acquiring their Gary property, had recently appointed three men to the inaugural Gary School Board. This board consisted of: C. Oliver Holmes, secretary of A.F. Knotts and agent of Gary Land Company; Thomas H. Cutler, civil engineer for U.S. Steel Gary Works; and Edward Jewell, also employed by the steel company.

15 Taylor, Satellite Cities, 218-219.
} 
build his progressive school system from scratch, Wirt tendered his resignation to Bluffton in July 1907. ${ }^{16}$

\section{The School Plant}

Upon his move to Gary, Wirt found himself charged with a tall, but surmountable task: to go beyond the physical and environmental constraints he faced in Bluffton, and to translate his education system into an urban industrial community from scratch, including facilities, faculty, and practice. Prior to taking the position in Gary, he prepared for this transition by touring the schools of Western Europe, specifically harvesting industrial education techniques from German public schools. At the turn of the twentieth century, Germany turned to management experts to reformulate the organization of their public school system. Based upon the idea that education created a product, experts theorized that applying the same industrial manufacturing concepts to primary and secondary education would produce similarly uniform quality graduates. From this, Wirt developed his definition of an ideal "school plant": room for play and exercise, intellectual study, specialized work in laboratories and shops, and social and expressive work in auditoriums or in the community. ${ }^{17}$

Wirt took these lessons and recruited St. Louis building commissioner William B. Ittner as the architect for Gary's six proposed schools. Ittner introduced the "Open Plan" school, orienting wings of the building in an $\mathrm{H}, \mathrm{U}$, or E shape to maximize natural light, ventilation, and potential for expansion. Open Plan schools featured classrooms on only one side of the hallways, with central gymnasia and auditoriums, and modern plumbing and fireproofing. The son of a master mason, Ittner used his own masonry expertise to embellish the otherwise purpose-built edifices with intricate patterns and textures of brickwork. Wirt admired the efficiency of Ittner's schools, and appreciated their aesthetics as Gothic and Colonial Revival civic monuments.

Officials of the Gary Land Company were eager to replace the one-room schools and mobile classroom units the city had subsisted on with a public school system that reflected the exponential growth of the young city, and served as advertisements of city development. However, when Ittner was unavailable to start work in Gary immediately, the Company decided they could not wait for the famed designer. To Wirt's dismay, Gary Land Company announced the construction of the city's first permanent school in late 1907. Not unlike the city itself, the three-story brick edifice was built on a more traditional, utilitarian layout without Wirt's or Ittner's guidance: geometrically-oriented rooms organized by grade with regulation desks and classroom furnishings.

Wirt met the news with disdain, complaining that a school built outside of his specifications would be insufficiently appointed and an unneeded cost. His objections went unheeded, and the Gary Land Company began construction of the Thomas Jefferson

\footnotetext{
${ }^{16}$ Cohen, Children of the Mill, 5-7.

${ }^{17}$ Randolph Silliman Bourne, The Gary Schools (Boston: Houghton Mifflin, 1916), 14-16.
} 
School at the intersection of West Sixth Avenue and Jefferson Street. (Figures $3.2 \& 3.3$ ) Described as "purely a philanthropic proposition on the part of the Gary Land Company," the school was leased to the school board for several years. Construction delays prevented Jefferson School from opening until September 1908, and in that time erection of Ittner's first local school had begun. ${ }^{18}$

Ittner was hired to design the first school to Wirt's specifications, Ralph Waldo Emerson School, which opened in 1909. ${ }^{19}$ (Figure 3.4) Located in Gary's First Subdivision at the intersection of East $7^{\text {th }}$ Avenue and Carolina Street, Emerson School was proclaimed the "ideal school plant" for the Platoon plan. (see Fig. 3.3) Wirt charged Ittner with providing space for thirty classrooms with room for thirty students apiece, seven science laboratories, a gymnasium, specific rooms for art and music studios, and workshops for manual training. (Figure 3.5) Individual rooms were set up for food science, sewing, drafting, visual and performing arts, chemistry and natural sciences. Extensive playground facilities were developed, as well as space for animal husbandry and a petting zoo. Furthermore Ittner installed the nation's first indoor school swimming pool and auditorium, as well as two woodworking shops. Within two years, the workshops were retooled for cabinetmaking, printing, and painting classes. ${ }^{20}$

Although the initial outfitting of Emerson school reflected the sorts of "industrial" classes favored by reformers like Dewey and Morris, it appears that in a company town like Gary, more practical and vocational industrial arts would supplant them. By 1912, three metal shops were added to provide for foundry, forge, and machine shop courses. ${ }^{21}$ A 1918 survey of the Emerson machine shop described a 735 square-foot workspace equipped with three electric screw-cutting lathes, a universal milling machine, two drill presses, and a grinder. Five vices were set up near cases of hand tools for fine work. The shop allowed for seven pupils to do productive work at one time. ${ }^{22}$ However, that number of students, as well as the levels of intangible work being done, was far greater under the integrative curriculum of Wirt's "Work-Study-Play" System.

\section{Equal Time and Equal Importance for Work, Study, and Play}

In 1915, John Dewey, now an admiring colleague of Wirt, described the intention of Wirt's Platoon System as looking beyond both traditional academic bookwork and training for specific skilled trades. Indeed, he advocated "not to train workers for a trade,

\footnotetext{
${ }^{18}$ Cohen, Children of the Mill, 6; Gary Board of Trustees, "The School Town of Gary," in First Annual Report of the Board of Trustees of the Town of Gary, Ind. for the Year Ending Dec. $31^{\text {st }}, 1908$ (1909), 4969.

${ }^{19}$ Gregg Abell, "Registration Form for Gary-Roosevelt High School," in National Register of Historic Places (U.S. Department of Interior, 2010).

${ }^{20}$ William Paxton Burris, The Public School System of Gary, Ind. (Washington, D.C.: Government Printing Office, 1914).

${ }^{21}$ Charles Russell Richards, The Gary Public Schools: Industrial Work (New York: General Education

Board, 1918), 3-4.

${ }^{22}$ Ibid., 25.
} 
but to make use of the whole environment of the child in order to supply motive and meaning for the work." While Dewey recognized the monoeconomic environment of many industrial communities such as Gary, as well as its intimate connection with the wellbeing of its citizens, he applauded Wirt as the harbinger of industrial education crafted with a "sincere interest in education and in the welfare of the community." 23

William Wirt gave his plan for progressive, efficient public education the candid name of "Work-Study-Play Schools." In this scheme, the school was used completely at all times. The student body was divided into two or more "platoons": when one would be working in the traditional academic subjects, the other would be engaged in special subjects or supervised play, and so on. Students did not have an assigned classroom in which they remained all day; instead, each pupil was given a steel locker in which to keep their effects. This allowed children to circulate through the school plant throughout the day, effectively doubling the school plant's capacity. The duplicate nature of the platoon system undermined the "peak-load" organization of a traditional school, which demanded a single seat be available for all students in all of a school's facilities at all times. Instead, no facilities were ever left idle by the consistent rotation of the platoons. In this way, Wirt introduced departmentalized education for all grades. ${ }^{24}$

It is no coincidence that the Platoon System's implementations of total facility use via departmentalization became popular concurrently with the theory of scientific management. Characterized by analysis of workflow and efficiency in manufacturing, the practice was introduced to American industry by mechanical engineer Frederick Winslow Taylor in the early twentieth century. The Efficiency Movement—better known in homage as "Taylorism"- -hit its peak of popularity with the 1911 publication of his monograph The Principles of Scientific Management. The book's tenets of empiricism, elimination of waste, knowledge transfer, and establishment of best practices ("the one best way," as Taylor put it) was quickly adopted by industrialists wishing to maximize production and profits. ${ }^{25}$ Similarly, Progressive Era reformers celebrated the aspects of Taylorism that quashed "tradition for tradition's sake" in the workplace and culture, seeking to adapt it to all seemingly antiquated sectors of society. Though this included education, there is no evidence of direct links between Scientific Management and the Gary schools. However, the temporal link to the directives of the Progressive Movement is undeniable.

A typical eight-hour day for a Platoon member in a Gary school consisted of balanced periods of academic and laboratory-based classwork, "auditorium,"

\footnotetext{
${ }^{23}$ John Dewey and Evelyn Dewey, Schools of Tomorrow (New York: E.P. Dutton \& Co., Inc., 1915), 181.

${ }^{24}$ Cohen, Children of the Mill, 22; G. W. Diemer, "The Platoon School," The Elementary School Journal 25, no. 10 (1925): 734-735.

${ }^{25}$ Frederick Winslow Taylor, The Principles of Scientific Management (New York: Harper \& Brothers Publishers, 1911).
} 
"application" or supervised play, recess, and lunch. By grade level groupings, platoon cycled through their prescribed periods of work, study, and play as follows: ${ }^{26}$

\begin{tabular}{|l|l|}
\hline \multicolumn{2}{|c|}{ Grades 1 through 3 } \\
\hline Academic Work (Language, History, Literature, Mathematics) & 2 hours \\
\hline Handwork and Drawing (Music, Arts) & 1 hour \\
\hline Nature Study & 1 hour \\
\hline Play (Application, Recess) & 2 hours \\
\hline Auditorium & 1 hour \\
\hline Lunch (Taken at Home or in School Canteen) & 1 hour \\
\hline \multicolumn{2}{|c|}{ Grades 5 and 6 } \\
\hline Academic Work (Language, History, Literature, Mathematics) & 3 hours \\
\hline Helpers in Workshops, Science Laboratories, or Arts Studios & 2 hours \\
\hline Play (Application, Recess) & 1 hour \\
\hline Auditorium & 1 hour \\
\hline Lunch (Taken at Home or in School Canteen) & 1 hour \\
\hline \multicolumn{2}{|c|}{ Grades 7 through 12 } \\
\hline Academic Work (Language, History, Literature, Mathematics) & 3 hours \\
\hline Mechanical Drawing, Shop Work, Laboratory Science & 2 hours \\
\hline Gymnasium/Play (Physical Training, Application) & 1 hour \\
\hline Auditorium & 1 hour \\
\hline Lunch (Taken at Home or in School Canteen) & 1 hour \\
\hline
\end{tabular}

Table 3-1 Typical daily schedules in the Platoon System categorized by grade level and prioritization.

Students were enrolled in industrial training workshops and science courses on a probationary five-week basis. They were then allowed to choose which subjects interested them the most, and rotate through three such courses per year. Wirt argued that this further rotation allowed the lessons to be reinforced, but not to force a student who discovers he does not enjoy a certain choice to be stuck with it for an entire academic year. Furthermore, he assured any potential dissenters that this mandatory change created not factory workers and shop hands, but agents who understood work processes. ${ }^{27}$

Two other unique aspects about the Platoon school day were the application and auditorium periods. Application time allowed the pupils to explore and exercise the theories and techniques they were learning in the coursework through practical work. This might have involved a trip to the public library to learn how to find information relevant to their lessons, or determining how much concrete might be needed to lay a

\footnotetext{
${ }^{26}$ Table compiled from: Dewey and Dewey, Schools of Tomorrow, 133-134; Richards, The Gary Public Schools: Industrial Work, 6-7; Kenneth S. Volk, "The Gary Plan and Technology Education: What Might Have Been?," The Journal of Technology Studies 31, no. 1 (2005): 40.

${ }^{27}$ Dewey and Dewey, Schools of Tomorrow, 185.
} 
house foundation on their playground. Nature study courses might have used the time to maintain school grounds; music teachers frequently made application of their courses via folk dance. (Figure 3.6) Often these applications involved the whole platoon in verbal games, which reportedly aided foreign students in their English language and social development. $^{28}$

In 1914, Wirt supplemented application periods with the allocation of "Released Time." The alternative period allowed students, with parental permission, to attend the religious education of their choice. Agreements were reached with a number of Protestant and Roman Catholic churches and Jewish synagogues near the schools to offer religious courses at four times throughout the day. Despite concerns about sectarianism and the intersection of church and state in public schools, conflict was largely avoided by holding the elective courses off-campus. ${ }^{29}$

Having keenly observed the popularity of released time in the Gary Schools, U.S. Steel head Elbert H. Gary rewarded the district with a \$10,000 grant. He expressed his pleasure in the positive moral and Americanizing effects the largely Protestant program had on the pupils and their families, but was more interested in the influence on the city's labor pool. In 1916, he wrote to newspaper magnate William Randolph Hearst: "I have been very much interested in the schools at Gary because of their practical effect upon the boys and girls of out workmen and consequently upon the workmen themselves." 30 Judge Gary maintained this grant off and on throughout the 1910s, contributing when he deemed it a priority. There is, however, no evidence to show he wielded financial influence over the curriculum of the Gary schools.

The majority of Gary school plants were built around a central auditorium suited for drama, music, and oration. Auditorium periods varied daily from sing-alongs, presentations by fellow students, slide shows, and lectures given by community leaders. The point of auditorium, according to department leader Mildred Harter, ${ }^{31}$ was to connect children to their school and home communities while training them in oral communication and the expressive arts. Instructors also planned the auditorium themes in conjunction with students, which allowed for the debating of school policies, or presentations on chemistry experiment results. Progressive author and Wirt-profiler Randolph S. Bourne indicated that these cross-grade experiences fostered curiosity among the younger children, as well as "sympathy between the pupils, makes each child familiar with the activities of the whole school, and prevents that unfortunate segregation and confinement of the ordinary school." 32

\footnotetext{
${ }^{28}$ Bourne, The Gary Schools, 72-73; Dewey and Dewey, Schools of Tomorrow, 144-145.

29 "Rabbi Praises Gary School Way of Religious Teaching," Chicago Daily Tribune, 5 March 1916, A3; Cohen, Children of the Mill, 40.

${ }^{30}$ Cohen, Children of the Mill, 62.

${ }^{31}$ Harter became the head of Gary school district's Auditorium Department in 1929, after eleven years teaching in the schools. She later became an authority on the role of expressive arts in primary education, and in 1926, Wirt's third wife.

${ }^{32}$ Bourne, The Gary Schools, 51.
} 
Gary school pupils had a sense of community responsibility instilled in them early on. Students gained pride of place when they have built, maintained, and served in parts of their own school. Wirt's belief that the ideal school plant was a unit school, housing scholars in kindergarten through grade twelve, lent to this sense of pride and duty. In the sixth grade, students selected the field in which they wished to pursue specialization. These specializations included industrial vocations such as plumbing or printing, academic concentrations in the sciences or arts, or business endeavors assisting in the office or school bank. ${ }^{33}$ Popular opportunities for girls included dress-making, stenography, and food science. In grade seven, the pupils delved into their specializations for a full year, without elective rotations. Additionally, they took on the mentoring of grade school students in their field. As younger students observed and assisted older students as helpers in their workshops, they maintained their love of handwork and cultivated their curiosity for and understanding of technical processes. ${ }^{34}$ This message of good citizenship and community responsibility was telegraphed on the back of Froebel School's schedule programs:

It is desired that the entire school be as much as possible like a family wherein the younger children are learning consciously or unconsciously from the older children and the latter from contact with the younger children are learning to assume responsibility and take the initiative. Someone has said that we send our boy to school but his playmates, not the school faculty, educate him. This is true because in the traditional school the faculty does not utilize the playmates as assistant instructors. ${ }^{35}$

Obviously, fostering a sense of community early in school children would result in civicminded, engaged adults and devoted employees. This intention went beyond Gary's youth, however, by way of the Gary schools' extensive-and popular-evening, adult, and citizenship education programs.

\section{Schools as Community Centers, Adult Education, and Americanization}

Ever the reluctant urbanite, William A. Wirt eschewed the notion of unsupervised time for the city child. As modern conditions including work, urban congestion, and insular ethnic groupings took the decentered family from their home, he declared the need for specialization to carry into the day-long care of children: "The city home is no longer able profitably to occupy all of the time of the child out of school...it is the city streets and alleys, amusement halls, and gambling dens which provide activities on the

\footnotetext{
${ }^{33}$ Emerson School Bank started in 1912 as a way to teach students frugality and thrift. Savings accounts were backed by Gary State Bank, and paid three percent interest. Cohen, Children of the Mill, 25.

${ }^{34}$ Dewey and Dewey, Schools of Tomorrow, 183-189.

${ }^{35}$ Richards, The Gary Public Schools: Industrial Work, 12.
} 
average for all the children of the cities." ${ }^{36}$ And of course it was industry that created cities, but then industry, too, disdained idleness of "soldiering" on the job. To attract children, and their urbanized families into staying busy with wholesome activities, the school plant had to take on new roles.

Early on, Wirt declared that in order to achieve complete utilization of school plants, they must be open to the entire community. Recognizing the need for combined economy and community engagement, in 1913 the Gary School Board declared that "the schools will be thrown open to the communities as club rooms and meetings may be held as often as is desired, and entertainments of all kinds which will furnish social intercourse in every part of the city." 37 This meant that students, parents, and citizens at large had access to the schools' gymnasia, playgrounds, swimming pool, and auditoria after the normal school hours of 8:00 a.m. to 4:00 p.m. ${ }^{38}$ Community engagement was also encouraged via increasingly popular night school courses that began as instruction in English language and American culture aimed at foreign-born Garyites.

By 1910, the proportion of children born to immigrant parents in Gary made up 63.4 percent of the city's school enrollment. ${ }^{39}$ Gary's large and varied immigrant population necessitated a school system that could both get them up to speed with their native-born peers, but also serve as a clearinghouse of American culture, civics, and vernacular. In 1908, the nativist Gary Daily Tribune editorialized that many southern and eastern European immigrants had not attended school themselves, and therefore discounted or feared the imposition of the American school system on their children. To quell this misunderstanding, Wirt and his Assistant Superintendent implemented a program that, rather than forcing families to come to the schools to register, sent district representatives into the community to enroll students. However, the program was not foolproof, as large swaths of European and southern black immigrant children living in "The Patch" fell through the enrollment cracks due to some agents' unwillingness to enter these feared and unsavory areas. Despite this, the personal visits, combined with explanations of the family-wide benefits of enrollment increased student population from approximately 6,000 in 1915 to 9,000 by 1920 . Threats of fines for truancy sealed the agreements. $^{40}$

Historian Ronald D. Cohen opined that in Gary, "Americanization did not mean a narrow indoctrination, but a broad educational experience," involving all levels of an immigrant child's_-and vis-à-vis, their family's — social health and welfare. ${ }^{41}$ This started early in the schools; more specifically, in kindergarten. Once helmed entirely by private institutions, the rising rates of poverty and declining pediatric health brought

\footnotetext{
36 "School Platoons," Chicago Daily Tribune, 27 June 1924, 8.

${ }^{37}$ Gary Daily Tribune, (either 1 February 1913 or 14 February 1913), n.p., quoted in Cohen, Children of the Mill, 32.

${ }^{38}$ Dewey and Dewey, Schools of Tomorrow, 132.

${ }^{39}$ Aggregate census data indicates that this percentage was approximately maintained through 1930. Mohl and Betten, Steel City, 134.

${ }^{40}$ Cohen, Children of the Mill, 47.

${ }^{41}$ Ibid., 23.
} 
kindergarten firmly into the realm of public schooling. In September 1908, the school district's first kindergarten opened to 23 tots. Cohen further asserted that "An important thrust of the kindergarten was to Americanize the preschool immigrant children by exposing them to English and in general weaning them from the perceived cultural limitations of their family environment." 42 Indeed at this time, non-English speaking immigrants were already 56 percent of Gary's population. Native languages that were spoken at home were often spoken in the unskilled work groups of the mill.

Kindergartens served as a way to introduce and indoctrinate immigrant children to the English language (and to democracy) early, subsequently earning the trust and piquing the interest of the parents. ${ }^{43}$

The successes and perceived value of Americanization expanded rapidly through the 1910s. Immigrant students were said to thrive in the Work-Study-Play program, as they were afforded opportunities to prove to themselves what they were capable of in their new environment. Additionally, progressive evaluation technique based upon quality, rather than quantity or speed, allowed both slower and non-native students to "keep up" with their peers. Constant exposure to a culturally heterogeneous cohort, combined with one-on-one attention from mentors and instructors for immigrant students and their families kept the entire household engaged. ${ }^{44}$

As early as 1909, the Gary School District conducted night school classes to accommodate working immigrants with a thirst for American education. Courses in English were offered free to adults, drawing a crowd of twenty-five students their first night. Soon after, courses were expanded to other civic topics including history and geography. The efforts of both the school districts, and attending immigrants, were met with glowing praise in the local press. Following the opening of Emerson School in 1910, a far broader curriculum was made available to all night school attendees, including several academic subjects and yet more industrial arts courses. While night school was open to all Gary residents, focus was kept on the immigrant. It was in fact portrayed as the humanitarian duty of all Americans to aide immigrants: "when they have found the work which brought them from the huts of poverty and want in Eastern Europe, it is certainly the bounden duty of the native-born to put forth a helping hand in their Americanization." 45

By the following year, adjustments to state law allowed the major expansion of the night school programs. Courses were held four nights per week from 7:00p.m. to 9:00p.m., with over 1,100 enrollees at Emerson alone. The most popular courses were the most practical: mechanical drawing, business and office management, chemistry, dressmaking, and commercial applications. However, English language continued to be the most prominent choice in the night school courses, and special accommodations were made to meet the demands. Several portable classrooms were assembled on Fourteenth Avenue in The Patch for the express purpose of English night school. Arrangements were

\footnotetext{
${ }^{42}$ Ibid., 11.

${ }^{43}$ Quillen, "Industrial City: A History of Gary, Indiana to 1929," 162.

${ }^{44}$ Dewey and Dewey, Schools of Tomorrow, 147, 186, and 192.

${ }^{45}$ Editorial, Gary Daily Tribune, 30 November 1910, n.p. Quoted in Cohen, Children of the Mill, 31.
} 
made with the local YMCA to set up courses in taverns and billiards rooms in order to conduct classes in social environments more familiar or comfortable for immigrant men.

As night school enrollment crept over 3,000 by 1914, their use as a tool of community-building and Americanization had solidified. "The night schools of Gary are the saving grace of Gary...Without them the leavening process by which twenty-nine different nationalities are being leavened into perfect American citizenship, would be impossible." 46 However, no one was happier about this than the heads of Gary Works. The night schools served not only to indoctrinate and educate foreign-born families, but to teach heavy industrial skills to young men. So enchanted were mill officials that employees were readily released from their shifts to teach night classes in English, chemistry, and metalworking. Immigrant steelworkers were similarly released to attend language courses, which allegedly produced remarkable results. ${ }^{47}$

The role of Gary schools in the Americanization process was set in stone with the opening of Froebel School in 1912. Named for Friedrich Froebel, the German pedagogue behind the invention of the kindergarten, the school was immediately marked as "the immigrant school." (Figure 3.7) Built on the site of English language night school portable classrooms in the heart of The Patch, the massive unit school was set to be the perfect Americanization depot. (see Fig. 3.3) Centered around a thousand-seat auditorium, the school plant was to include two indoor swimming pools with locker space for 2,000, two large student-run gardens, a six-acre playground, and an on-campus public park. (Figure 3.8) The classrooms and workshops, it seemed, were almost an afterthought. Workshops for plumbing, tinsmithing, and cabinetry for boys accompanied space for millinery, stenography, and cooking for girls. The diverse variety of study at Froebel contributed directly to its curious 1915 enrollment figures: as many students were enrolled in day school as were in night school. ${ }^{48}$

Both day and night school at Froebel proved popular to immigrant families, demonstrating to the school board that a genuine need was being fulfilled. By 1916, 87 percent of the school's population was foreign-born, largely from eastern and southern European countries. However, with the advent of World War I, attendance of Americanization courses became even more strongly advised to immigrants. Patronization of English classes offered by the school district was encouraged over those offered by area ethnic beneficent societies, lest the lessons be tainted by socialist leanings, a concern made more relevant by the Russian Revolution in 1917. Naturalization was also stressed by word-of-mouth as a qualifier for promotions at U.S. Steel. By 1924, this led to twenty English courses taught throughout the city's night schools - five at Froebel alone - that held the esteem of both the U.S. Department of Labor and the Bureau of Naturalization. When Gary immigrants applied for American

\footnotetext{
46 Gary Evening Post, 3 October 1913, n.p., quoted in ibid., 32.

47 Ibid., 33.

${ }^{48}$ Burton J. Hendrick, "Children of the Steel Kings," McClure's Magazine 41, no. 5 (1913): 66; Graham Romeyn Taylor, "Satellite Cities - V. Gary," The Survey 29, no. 22 (1913): 734.
} 
citizenship, they were often instructed to attend the school district's English and civics classes. ${ }^{49}$

However, despite the rush to congratulate the successes of Gary schools' Americanization offerings, many immigrants were left disenfranchised by the process. The school's emphasis on efficiency often steamrolled the ethnic heritage and personal identities of the foreign-born and first-generation students. Native-born instructors arbitrarily assigned pupils American names. Open criticism of supposedly backward customs and dress was encouraged in the classroom and on the playground. Night school instructors called adult pupils by their surnames, which was in their cultures a pejorative manner of addressing servants or inferiors. The result was large-scale immigrant disenfranchisement with a program that sought "to crush out every spark of love and attachment...toward the land of [their] birth," and a night school program increasingly dominated by native-born Garyites who did not require Americanization. However, the program fit well into Wirt's values of "order, self-discipline, and obedience to authority." Indeed the "romance of Americanization" written in Gary night schools described in the local press may have been just that: a romanticization of a necessary process, and "Americanization factories" producing Americans to work in the factories. ${ }^{50}$

\section{Implementation Outside Gary Meets Criticism}

The ongoing flood of praise for the Gary Plan came as a result of constant selfpromotion, demonstration of economy, and pedagogical curiosity. Its first note of public praise occurred in 1910 as a glowing review of the manual arts facilities in Jefferson and Emerson Schools featured in The Iron Age, a leading trade magazine for the iron and steel industry. The author applauded the municipality for channeling its funds not into showy city monuments, but rather into the schools "which appeals with peculiar force to the merchant or workingman who wants his children to grow up with educational advantages." 51 With such strong, concise praise featured in the era's premiere steel industry journal, a wide range of readers had their interests piqued. Soon after, German pedagogical journal published in Berlin, Das Schulzimmer, published a thorough profile of Emerson's facilities and implementation of the Platoon System. Feature articles appeared in popular American periodicals Pictorial Review and Hampton's Magazine, where Wirt assured eminent muckraking writer Rheta Childe Dorr that Gary children were not kept in school "from morning until close to bedtime," but rather given opportunities to stay busy in the school's classrooms, workshops, and recreational facilities. ${ }^{52}$

\footnotetext{
${ }^{49}$ Cohen, Children of the Mill, 89.

${ }^{50}$ Ibid.; Mohl and Betten, Steel City, 134-135, and 145.

51 "Civic Development at Gary," The Iron Age 85 (1910): 673.

52 Rheta Childe Dorr, “Keeping the Children in School," Hampton's Magazine, 27 (July 1911): 57-59, 64, quoted in Cohen, Children of the Mill, 26-27.
} 
After reading these accounts and others, and seeing the numerous photos published along with them, Emerson was quickly overwhelmed by up to 500 visitors from around the world per week, wishing to see how this new form of common school could benefit their own cities. These eager observers were given a packet that explained "the entire school curriculum is planned to gradually but effectively transfer the play impulse of the child into a work impulse so that as he grows to manhood he will take the same pleasure in his work that as child he took in his play." ${ }^{25}$ The implication that this was education for future workers was made plain, though dressed up in progressive altruism.

The economical and fundamental benefits of the Gary Plan were most keenly observed by school officials visiting from districts in similarly working-class industrial communities. Not long after his 1911 visit, Superintendent S.O. Hartwell of Kalamazoo, Michigan converted one of the city's schools into a Platoon school plant. Shortly thereafter, plans were announced for similar conversions in the coal-producing towns of Hazelton, Pennsylvania and Bellingham, Washington. ${ }^{54}$ The burgeoning popularity of the Gary Plan took Wirt, and school board member William Flynn, foreman of Gary Works' rail mill, around the nation to lecture to eager crowds. Flynn and the upper echelon of U.S. Steel management were swept up in Platoon school fervor.

In 1915, president of new subsidiary Minnesota Steel announced to the Duluth School Board that his company was prepared to donate acreage and equipment for a school in their adjacent mill gate community, Morgan Park, so long as the school adhered to the Gary Plan. Intrigued, Duluth superintendent R.E. Denfield visited Gary to learn more; he returned with high praise, positing that the Morgan Park school could end up a model for all of Duluth. ${ }^{55}$ The proposal to implement the Gary Plan in Morgan Park and beyond was met with some skepticism in Minnesota's Iron Range. The wife of Max Alletzhauser, physical education director of Duluth schools, wondered "if the 'Gary' system is not an attempt to wean ornery people away from study and make strong husky steel hands of them." ${ }^{56}$ Dissent also came from the Socialist Club of Duluth who claimed that employing the plan in Morgan Park was U.S. Steel's means to control the school. Opposition was quickly quieted, however, by aggressive demonstrations of the school's success as both a place of learning and a gathering place for the industrial community.

As in Gary, the school at Morgan Park took full advantage of the school plant for modern, inclusive lessons in state-of-the-art, completely-utilized facilities. Manual and industrial courses were balanced with traditional academic fare, and auditorium and application hours played key roles in pupils' civic and communicatory development. In

\footnotetext{
${ }^{53}$ Emerson School, "Notes to Visitors" (pamphlet, 1911), 10, quoted in ibid., 28-29.

${ }^{54}$ Neither produced coal for U.S. Steel. Rather, collieries in Hazelton largely supplied competitor Bethlehem Steel.

${ }_{55}$ Arnold R. Alanen, Morgan Park: Duluth, U.S. Steel, and the Forging of a Company Town (Minneapolis: University of Minnesota Press, 2007), 190-195.

56 Alletzhauser, Elsie Braun. Letter to Elsa Alletzhauser, 1936. Quoted in ibid., 190. Husband Max led the Friday evening men's gymnastics course at Morgan Park School, part of the local Platoon System adult night school program.
} 
1917, adult night school was introduced with courses in mechanical drawing, cooking, physical education, and several sections of citizenship. Later that year, a course in steel mill chemistry was added. In all, over 4,000 people attended night school at Morgan Park in 1917. With the addition of a full high school the following year, the popularity and full utilization of the school plant declared the implementation of the Platoon System in Gary's northern sister city a complete success.

However, this was not the case with all adopters of the Gary Plan. Morgan Park, like Gary, was an industrial community built to order for a monoeconomic industrial community. Though under the jurisdiction of the Duluth School District, Minnesota Steel's settlement along the St. Louis River maintained the advantage of building its own school plant tailored to Work-Study-Play as dictated by the land agreement. Cities where these seeming advantages did not exist encountered difficulties when attempting to convert existing facilities and curriculum into a Platoon System.

The most notable failure of the Platoon System occurred in New York City. In 1913, city voter took a stand against cronyism in municipal politics by electing progressive mayor John Purroy Mitchel. The young politician introduced sweeping reforms to modernize and combat long-standing corruption throughout the city, including a trimming of the school board and reformatting of the school curriculum. Mitchel visited Gary in 1914 on a fact-finding trip, and quickly decided that the Platoon System would solve dual overcrowding and budget crises faced by New York City schools. Wirt, now famous for his progressive pedagogy, was hired as a part-time consultant to the city's school board to guide the conversion of 32 schools across the Bronx, Brooklyn, and Manhattan to Platoon schools. For the handsome sum of $\$ 10,000$ per year, and frequent trips East, Wirt had commodified his curriculum. ${ }^{57}$

However, the apparent celebrity of the Gary Plan in New York City was soon transformed into a cause célèbre. As Wirt undertook the challenge of converting P.S. 45, a severely overcrowded elementary school in the Bronx, criticism was quick to follow. Located in a working-class Italian neighborhood, the school was landlocked and unable to add on characteristic Platoon school facilities such as workshops, an auditorium, or large playground facilities. Instead, adaptations were made to the program, such as increased field trips for application time, and class period changes every forty minutes. However, when one of these periods was designated for religious education, initial plans only catered to the majority Catholic students. Local Jewish and Protestant leaders were furious, positing that the Platoon System was a "Catholic plot" to force conformity on the city's children. ${ }^{58}$

Nevertheless, Wirt forged ahead in converting another Bronx school, P.S. 89 in a similarly populated neighborhood. Here he was met with dogged soldiering and argumentation from teachers and administration displeased with the changes he proposed.

\footnotetext{
${ }^{57}$ David J. Hoff, "A Blueprint for Change," Education Week 18, no. 32 (1999); James M. Wallace, "A Gary School Survives: Angelo Patri and Urban Education," History of Education Quarterly 45, no. 1 (2005): 104.

${ }^{58}$ Diane Ravitch, The Great School Wars: A History of the New York City Public Schools (Baltimore: Johns Hopkins University Press, 2000), 197-230.
} 
Few were excited to take orders from an expert hired by the same mayor who slashed their salaries and funding in the name of efficiency, much less from a non-native from a "small town." Public outcry began in earnest, starting with concerns from local ethnic beneficent societies that their children were solely being trained for menial industrial jobs within the Platoon System. The Bronx Chamber of Commerce agreed, declaring "The Gary School is an obstacle to the Americanization of our foreign pupils. To please the foundations the city officials are making cheap laborers of our children and cutting every child off from the right to become a great man and a thinker of his own." 59 The sentiment was latched onto by Mayor Mitchel's opponents, causing it to spread quickly throughout the Bronx and its neighboring boroughs. Gary Plan proponents attempted to turn popular opinion by hosting visits from former President Theodore Roosevelt and experts from Columbia University, and publishing their praises of constructive play and its correlations to academic classwork. Unfortunately, this did little to stem the tide of dissent.

Concerned parents and city officials called the P.S. 45 principal Angelo Patri, a supporter of the changes Wirt introduced to his school, before a Bronx Grand Jury shortly before the New York City mayoral election of 1917, demanding to know if his school was now a trade school. He explained that while his pupils were instructed in the trades, as in Gary, it was balanced with traditional subjects and play in order to expand their curriculum and practical experience. The Grand Jury published their report just days before the election, proclaiming that "the work-study-play school idea was underdeveloped and entirely unadapted to the requirements of a city community." Reeling in the controversy generated by the ruling, Mayor Mitchel was swept out of office by a wide margin in the September 1917 election, as were the remaining elements of the Gary Plan in New York City schools and with them, Wirt's consultancy. ${ }^{60}$

The success of the Gary Plan in Morgan Park, and its contrasting tremendous failure in New York City demonstrates the curriculum's apparent suitability in differing circumstances. In one population center, it was established by decree from an industrial sponsor as a condition of their support. Morgan Park required a school as a key to U.S. Steel's welfare capitalism in their company town. Not unlike Gary, both the town and school system was built "from scratch" to support a new steel mill with no established potential worker housing. The town was guaranteed to be monoeconomic, and its demography heterogeneous and largely foreign-born. Instituting the Gary Plan here, in purpose-built school plants, to a population perhaps unfamiliar with any other types of common education, and few to no available alternatives, was relatively simple.

On the other hand, implementing a system of work, study, and play in a large, established city was only logical in the Progressivist fervor of the era. Four years before Wirt's employment by Mayor Mitchel, New York City's population topped four million-nearly 235 times the 1910 population of Gary. ${ }^{61}$ Its economy was varied and

\footnotetext{
${ }^{59}$ Quoted in Wallace, "A Gary School Survives," 106-107.

60 Ibid.

${ }^{61}$ New York City population in 1910: 4,766,883. (City of New York NYC Planning: Department of City Planning. "NYC Total and Foreign-born Population 1790-2000." Table, 
subject to different market variables than that of Gary. Additionally, New York City's public school system had been developed over a century of population and geographic growth. Adding bitter political rivalries to the relative speed of Mitchel's educational reforms did the movement few favors, as well. Despite adamance that it was not intended to make factory automatons out of immigrant children, the ideals of the Gary Plan were not suited to an established, economically diverse non-industrial community.

Nonetheless, defeat of the Platoon System in New York City did not stop its partial implementation in other cities nationwide. By 1930, Detroit boasted 121 schools on the plan, and Pittsburgh 86. Others, including Cleveland, Los Angeles, Seattle, Kansas City, Newark, and Birmingham, reported early successes with their own application of the curriculum. ${ }^{62}$ Few of these cities, though major, had the population, history, and broad economic base of New York City. Many were largely based on manufacturing, and had large foreign- and native-born minority immigrant populations. These facts give credence to the concerns about Gary Plan schools churning out immigrant factory hands initially posed in Morgan Park and New York City.

\section{Segregation in Gary Schools}

From the beginning, Gary schools were voluntarily racially segregated. William A. Wirt and his school board of U.S. Steel officials elected to cater to the city's AfricanAmerican school population by establishing a separate schoolhouse for them. ${ }^{63}$ In 1908 , Wirt rationalized that "it is only in justice to the Negro children that they be segregated. There is naturally a feeling between the Negroes and the whites in the lower grades and we believe that the Negroes will be better cared for in their own schools." 64 The rationale, while not completely unopposed, remained palatable to Gary's white elite, and to black transplants from the Jim Crow South, for the time being.

Through the early 1920s, Gary's African-American schoolchildren were crowded into a handful of all-black schools concentrated around "The Patch," later referred to as the Midtown neighborhood. The drafty frame schoolhouses were staffed by black faculty, and generally led by black administrators. For their manual training, pupils would be shuttled to Emerson to use the school's workshops when not occupied by white students. In 1914, night school was also opened to black adults with the introduction of an electrical course offered at the $22^{\text {nd }}$ Street School by Gary Works employee, Orestes

Gary population in 1910: 16,802. (STATS Indiana. "Indiana City/Town Census Counts, 1900 to 2010 Gary City." Table, http://www.stats.indiana.edu/population/PopTotals/historic_counts_cities.asp), accessed 30 June 2014.

${ }^{62}$ Raymond A. Mohl, "Alice Barrows: Crusader for the Platoon School, 1920-40," The Elementary School Journal 77, no. 5 (1977): 352.

${ }^{63}$ According to Mohl and Betten, legislation was passed in 1922 that permitted, but did not require, racial segregation in Indiana public schools. (Neil Betten and Raymond A. Mohl, "The Evolution of Racism in an Industrial City, 1906-1940: A Case Study of Gary, Indiana," The Journal of Negro History 59, no. 1

(1974): 54.)

${ }^{64}$ Mohl and Betten, Steel City, 55. 
Hood. Other popular, albeit segregated night school courses available to the black community included cooking and chauffeuring, which the local press lauded as admirable betterment efforts toward future careers. ${ }^{65}$

With the opening of Froebel School in 1913, Gary's black schools experienced some relief. As Gary's only "mixed" school, Froebel was not so much a racially progressive experiment as a reflection of the Midtown neighborhood itself. Long the first stop for all foreign-born and minority immigrants, Midtown remained racially integrated out of necessity through 1950. Still internally segregated by class, Froebel became Wirt's boilerplate answer to black families who expressed displeasure over the conditions of their neighborhood schools: if they didn't like it, they could always send their children to Froebel. ${ }^{66}$

Despite the relief offered by the opening of Froebel School, overcrowding in Gary's black schools reached a breaking point in 1927. Roosevelt Annex was filled to bursting. East Pulaski School, built 300 feet from its mirror image, all-white West Pulaski, provided some relief in a highly visible manner. However, it was the severe overcrowding and deplorable conditions of the all-black Virginia Street School on the edge of the Ninth Subdivision that caused Wirt to tentatively relax his segregationist beliefs. (see Fig. 3.3) The small school had no laboratories, lockers, or library, and the gymnasium was terribly undersized, which Wirt surely recognized as violations of key tenets of the Gary Plan. Consequently, he arranged for the transfer of eighteen black high school students to Emerson. Returning white students in the fall of 1927 were shocked to find their classes combined with black pupils, and responded with Gary's first student strike. ${ }^{67}$ Eight-hundred white students walked out of the first week of classes at Emerson, and were led by a brass band north on Broadway under a banner reading "We won't go Back Until Emerson is All White." Wirt attempted to reason with them, explaining that 1,600 more students had enrolled in Gary schools that fall, and that economic necessity forced his hand into this piecemeal desegregation. The explanation fell on deaf ears, however, and the strikers' numbers swelled to over one thousand.

No official resolution to the strike was reached, although a messy sort of compromise was reached. Striking Emerson students were allowed to return to school unpunished, and to "solve the problem" amongst themselves. The result was the return of the strikers to the classroom and the subsequent brutal treatment of the black pupils. The majority of African-American Emersonians succumbed to peer pressure, and had dropped out or transferred within a year of the strike. Additionally, $\$ 600,000$ was earmarked to convert the all-black Roosevelt Annex school into a full-fledged, state-of-the-art high school. (see Fig. 3.3) Opened in 1930, the Ittner-designed Colonial Revival school

\footnotetext{
${ }^{65}$ Cohen, Children of the Mill, 36-37; Dharathula H. Millender, Gary's Central Business Community, (Chicago: Arcadia Publishing, 2003), 37-52.

${ }^{66}$ Andrew Hurley, Environmental Inequalities: Class, Race, and Industrial Pollution in Gary, Indiana, 1945-1980 (Chapel Hill, NC: University of North Carolina Press, 1995), 30; Mohl and Betten, Steel City, 56. Hurley also cites the Sixteenth Federal Census: "As late as 1940, whites still constituted over 25 percent of Midtown's population, but by 1950, they comprised only 4 percent."

${ }^{67}$ Millender, Yesterday in Gary, 60.
} 
represented an unpleasant negotiation between segregationists and integrationists of both races: the black community now had their own Platoon System high school, but were firmly assured that they were indeed second-class citizens, unworthy of sharing all but a single designated school with their white peers. ${ }^{68}$ (Figure 3.9)

This early race-based revolt in voluntarily-segregated Emerson brought into question a number of Gary schools' practices that had been overlooked for decades. The Gary branch of the National Association for the Advancement of Colored People (NAACP), active since 1916, regularly registered complaints with the school board about the inferior facilities and supplies provided to the city's black schools. If black students were unable to transfer into better equipped white schools, they argued, then black students were falling behind their peers in what was allegedly a separate, but equal school system. In 1924, Virginia Street School principal, H. Theodore Tatum, challenged Wirt's edict that work and study gave children self-worth, countering that "The constant invidious comparison of his school environment [to that of white schools] serves to weaken in the child the attitude bases for loyalty, pride, self-respect, and whole-hearted cooperation." 69

The feeling was not universal throughout the black community of Gary. As early as 1921, John H. Smith of 1340 Carolina Street, summarized his support of the United Negro Improvement Association's (UNIA) stance on black separatist-based voluntary segregation in the Gary Daily Tribune: "I am sorry to hear that my friends, Dr. Garnett and Rev. Hawkins, were not instrumental in bringing about colored schools in Gary as well as they were in colored banks and colored churches to be controlled and operated by colored people and for the benefit of colored people." 70 Though locally strong, the sentiments of Smith and the UNIA were yet overshadowed by the integrationist attitudes of black community leaders like W.C. Hueston, influential African-American lawyer and Gary resident (and employer of Smith's step-daughter, Ella Mae Ross). Hueston challenged both white and black local segregationists in a 1924 letter to Wirt, declaring that "To tell new coming Americans that we have a separate school for them and one for Negroes, is to educate this new group in an incorrect way as to their attitude toward my race." 71

Historians Neil Betten and Raymond Mohl summarize Hueston's ominous prediction best:

Traditions, especially pride in nationality, could easily be transformed into a form of white superiority; anti-semitism, particularly among East Europeans, could evolve into racism. In Europe, the immigrants had lived in a world of class

\footnotetext{
${ }^{68}$ Abell, "Registration Form for Gary-Roosevelt High School."; Millender, Gary's Central Business Community, 38.

${ }^{69}$ Mohl and Betten, Steel City, 56.

${ }^{70}$ Quoted in Cohen, Children of the Mill, 93. Rev. Charles Hawkins was leader of the First Baptist Church and Dr. James Garnett, a former slave turned academic, was a Gary Schools probation officer and the founder of an all-black chapter of the Boy Scouts of America in Gary.

${ }^{71}$ Quoted in Mohl and Betten, Steel City, 56.
} 
antagonism and ethnic conflict, but the peculiar brand of American racism which taught black inferiority and sublimation had to be learned. The Gary establishment did the teaching. ${ }^{72}$

If indeed the Gary establishment taught the city's children ethnicity and class awareness, though, it was acted through the creation of a society in miniature created in each Gary school plant. The overarching themes of filling children's time, rather than allowing them to simply kill time fostered a highly-regimented day-to-day life for them and-through the introduction of night school and adult education - their families. This wholecommunity education offered many advantages to Gary's native and non-native populations, exposing children of all socioeconomic classes to skills and career paths often unobtainable to them otherwise. The focus on making well-rounded Americans of individuals with limited English skills, interest in school, or experience with school structure of any kind speaks to the innovative and adaptive nature of Wirt's Work-StudyPlay system.

However, the critiques Wirt faced in New York City were not far off their mark. Beyond the surface of the Platoon System lay an assembly-line style of education that strayed from fostering the superintendent's goals of inspiring "order, self-discipline, and obedience to authority," to demanding it absolutely. Evidence suggests that the largely eastern European and southern black enrollment at Froebel School were pushed into more trade-oriented classes than their mainly native-born peers across town at Emerson.

Subsequently, Froebel claimed high school graduation rates half that of Emerson School. By 1916, up to sixty percent of boys - and 63 percent of girls-dropped out of Gary schools after age 14 to go into industrial or domestic work. ${ }^{73}$ In this way, Wirt's Gary Plan schools became Gary Works feeders, sifting and winnowing ready-made Americans of all ethnicities into their prescribed futures. This demonstrates the corporate underpinnings of welfare capitalism in Gary, in which the indirect support of U.S. Steel for community-wide education not only provides them ready-made workers, but indoctrinates them to a placid and patriotic way of life. For a relatively limited investment, the steel trust ensures loyal, productive, and union-indifferent laborers from cradle to grave.

\footnotetext{
${ }^{72}$ Betten and Mohl, "The Evolution of Racism in an Industrial City," 51.

${ }^{73}$ Mohl and Betten, Steel City, 141-142.
} 


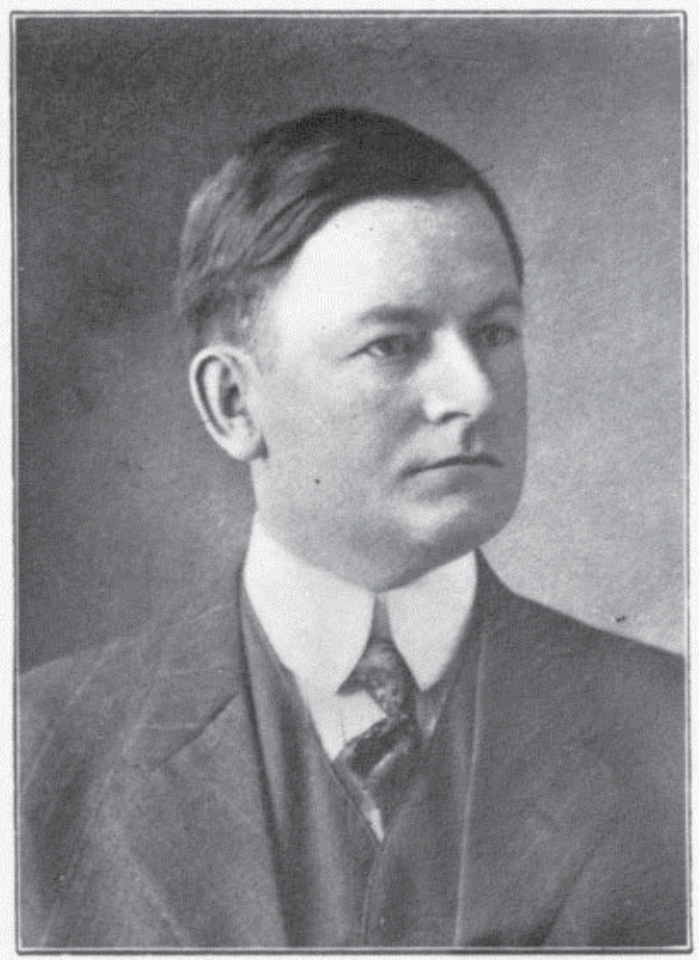

WILliam A. WirT

Superintendent of Schools

Figure 3.1 An undated portrait of Gary Schools Superintendent William A. Wirt. Image cropped from original. Courtesy of Calumet Regional Archives, Indiana University Northwest. 


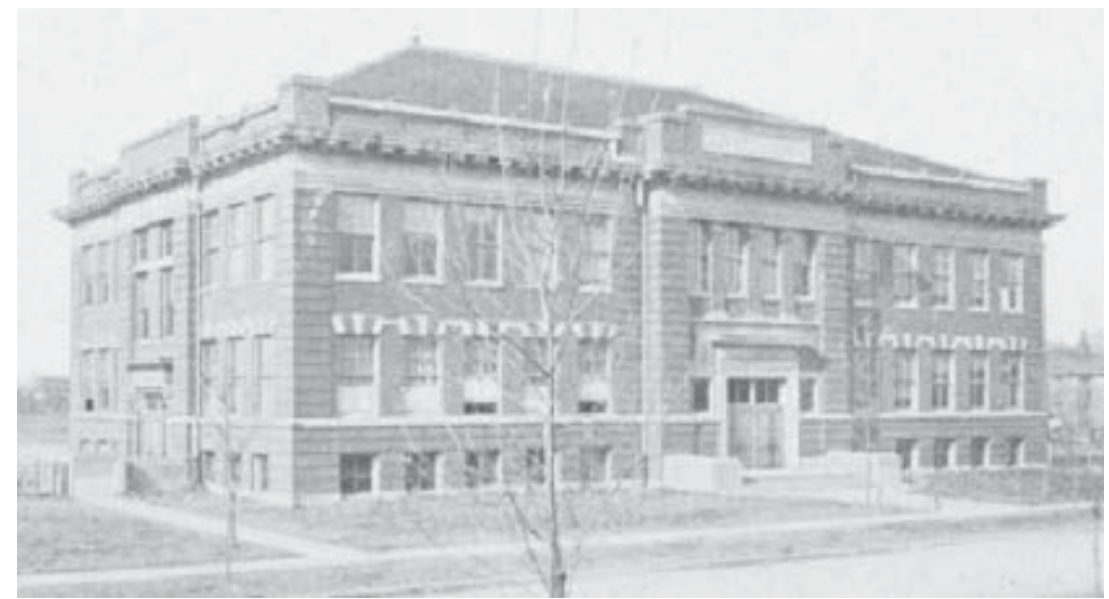

Figure 3.2 An undated photo of Jefferson School, showcasing its typical, non-Platoon school plant layout. Image reproduced from “Gary, Indiana: America's Magic City, 1906-1912” (1912), 9. 

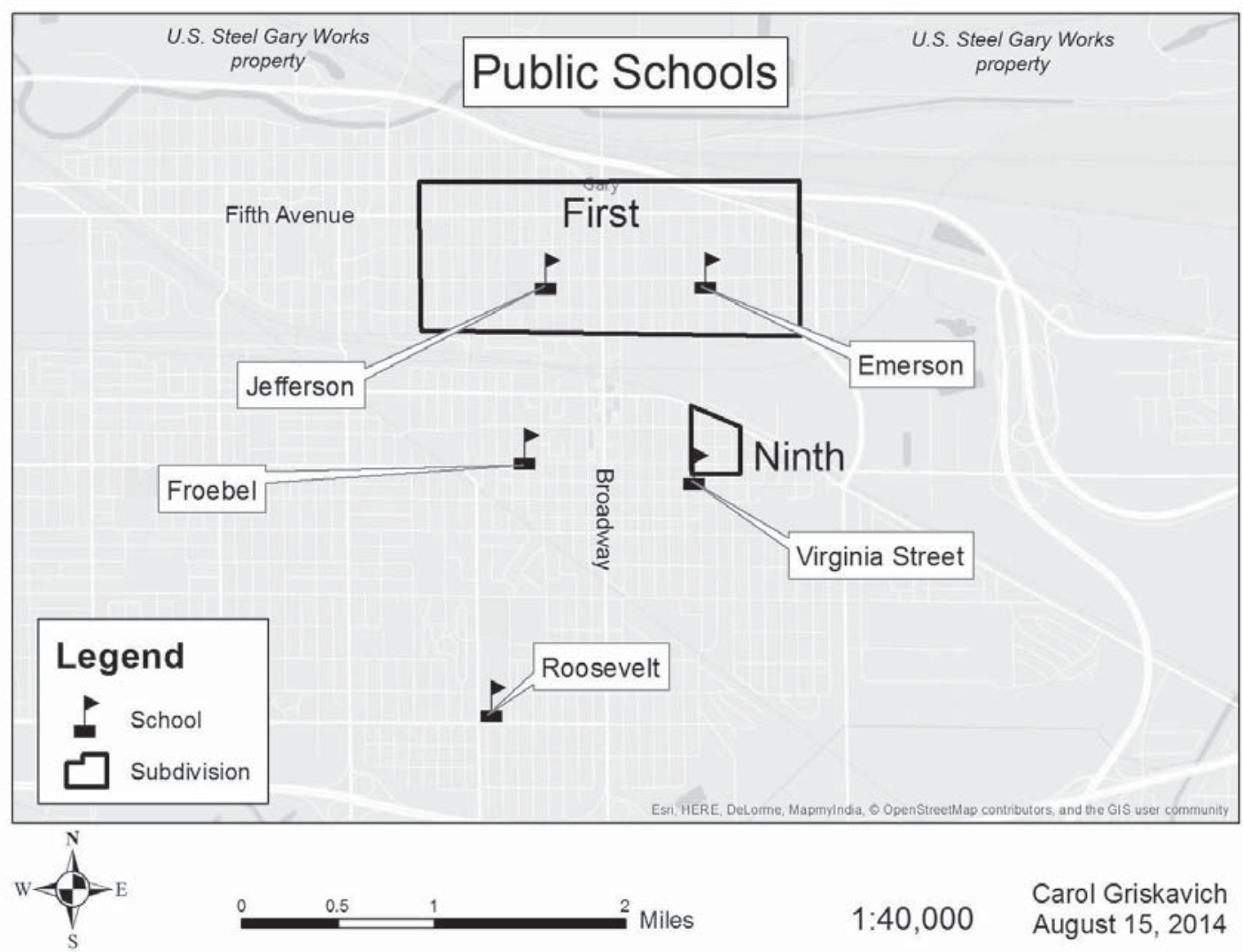

$1: 40,000$

Carol Griskavich August 15, 2014

Figure 3.3 Placement of Gary public schools. 


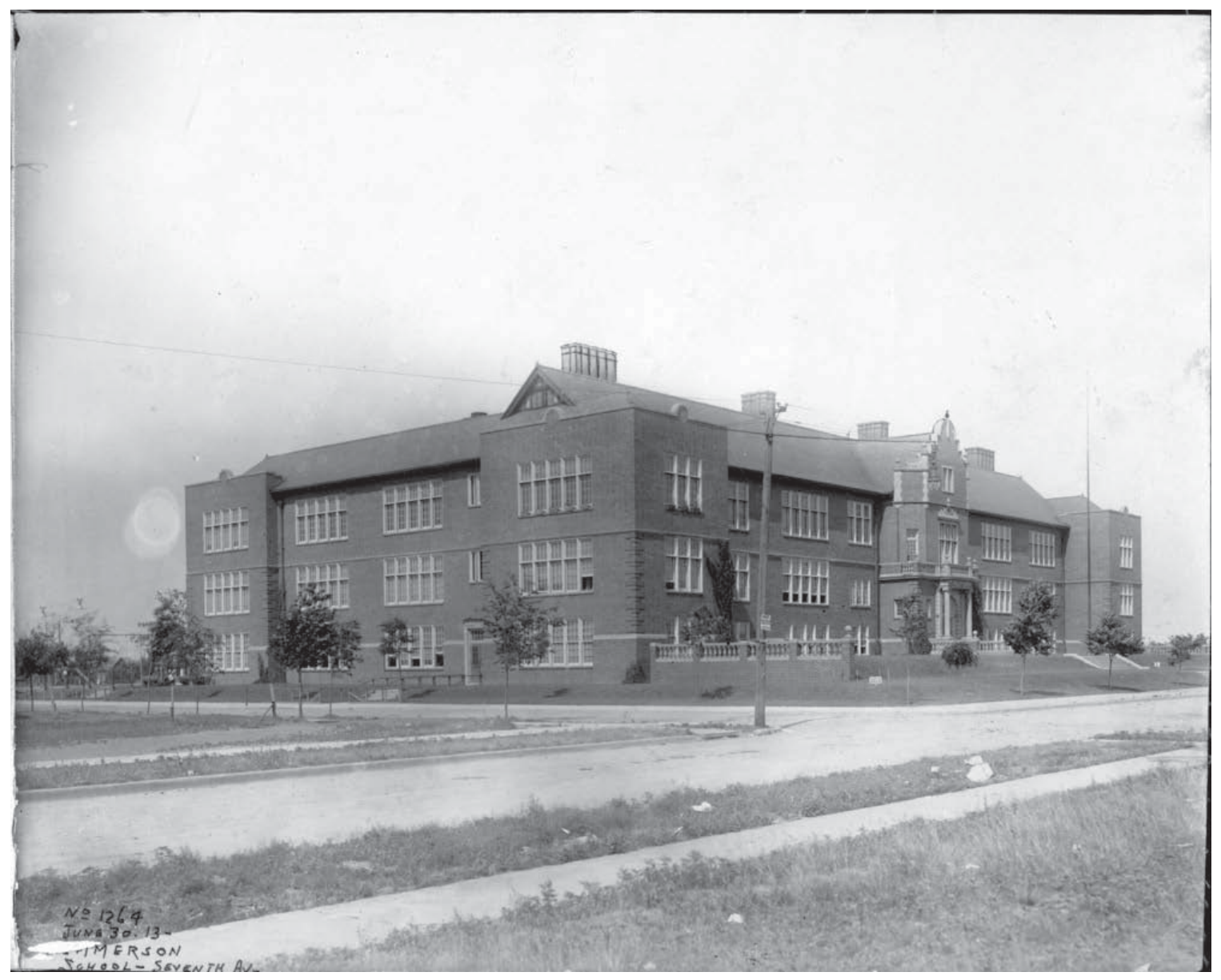

Figure 3.4 Emerson School in 1913. Courtesy of Calumet Regional Archives, Indiana University Northwest. 


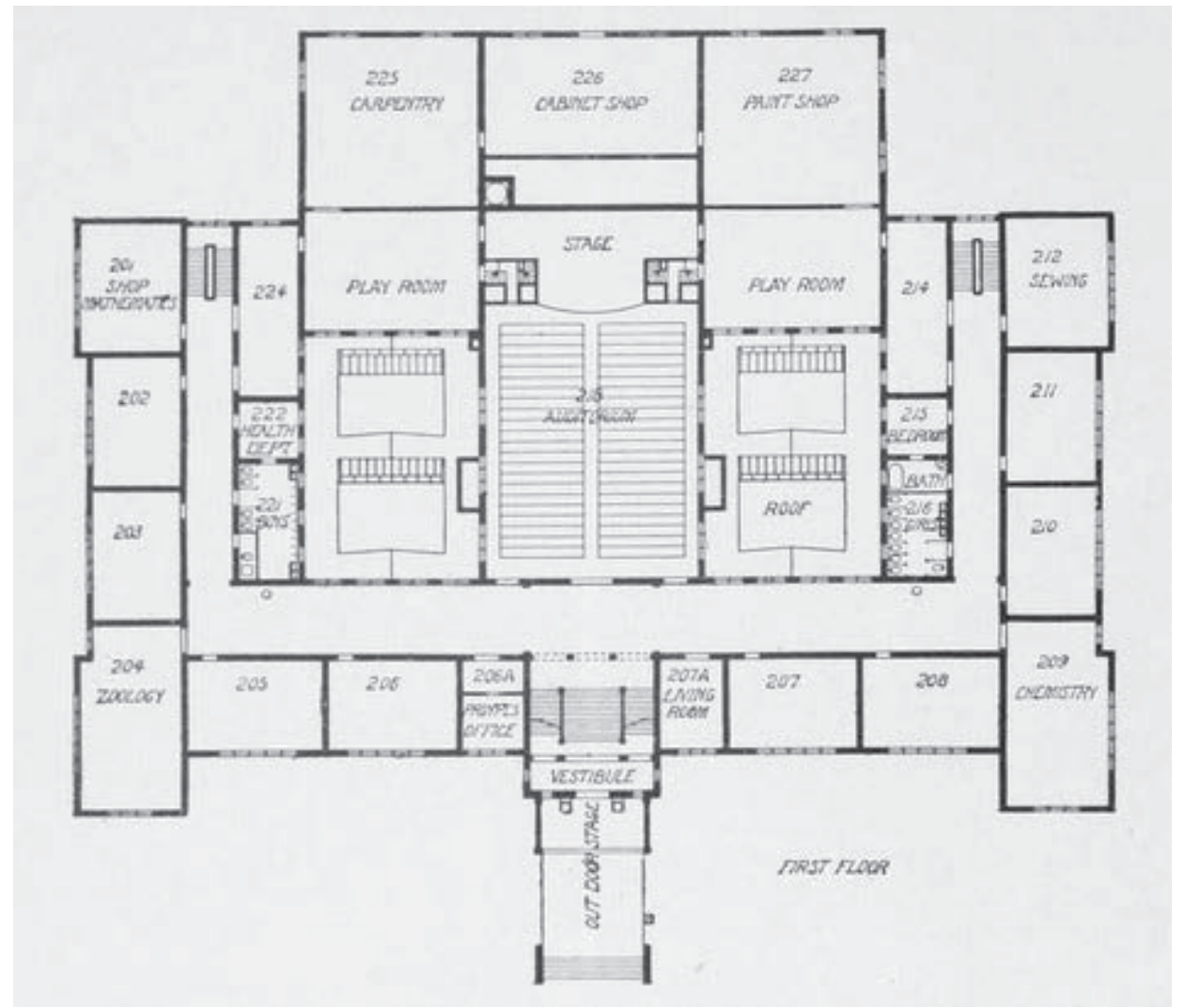

Figure 3.5 The first floor plan of Emerson School showcasing the auditorium and workshops, ca. 1914. Image reproduced from Burris, The Public School System of Gary, Ind. (1914), 9. 


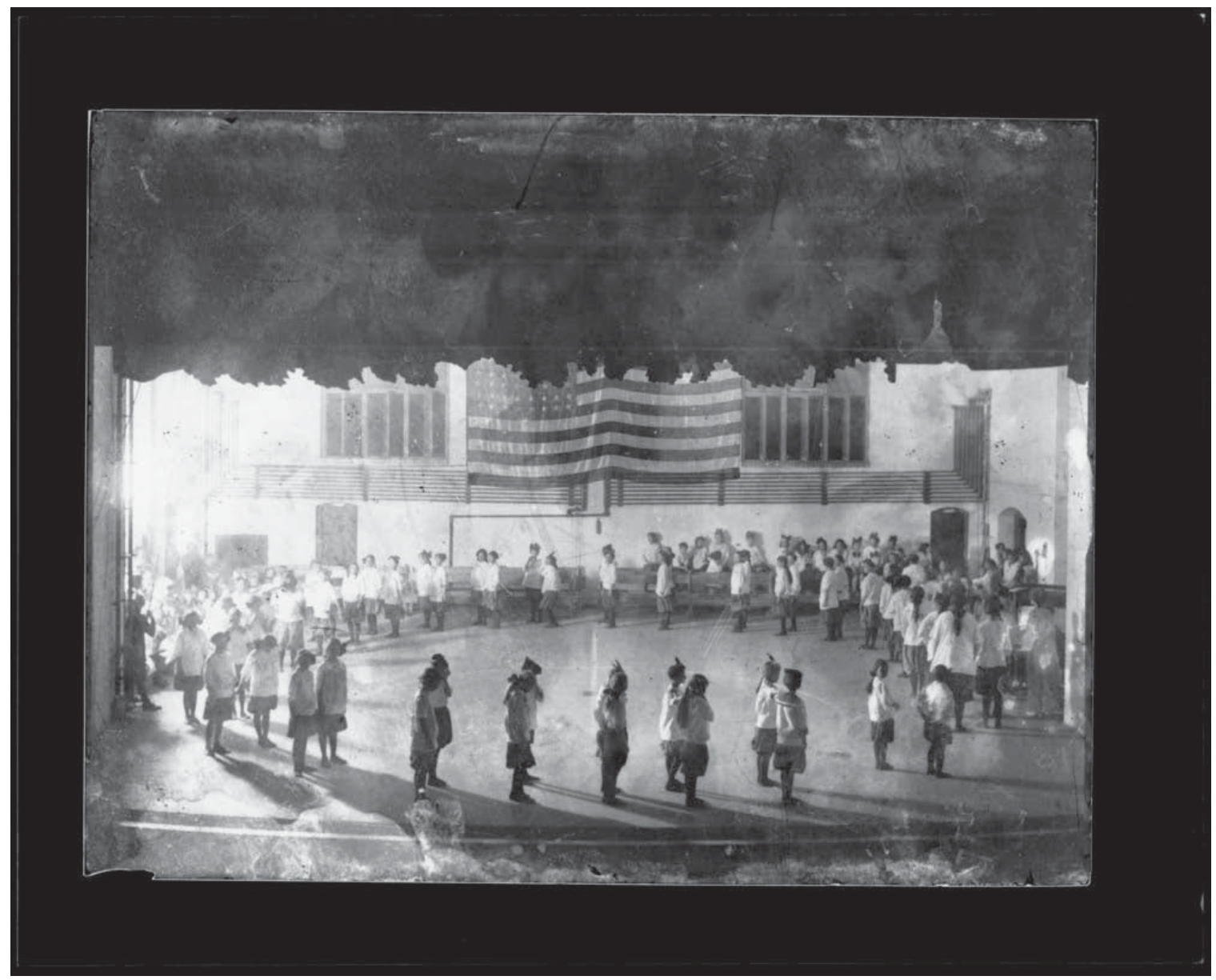

Figure 3.6 An undated photo of Gary students folk dancing in their auditorium during an Application period. Courtesy of Calumet Regional Archives, Indiana University Northwest. 


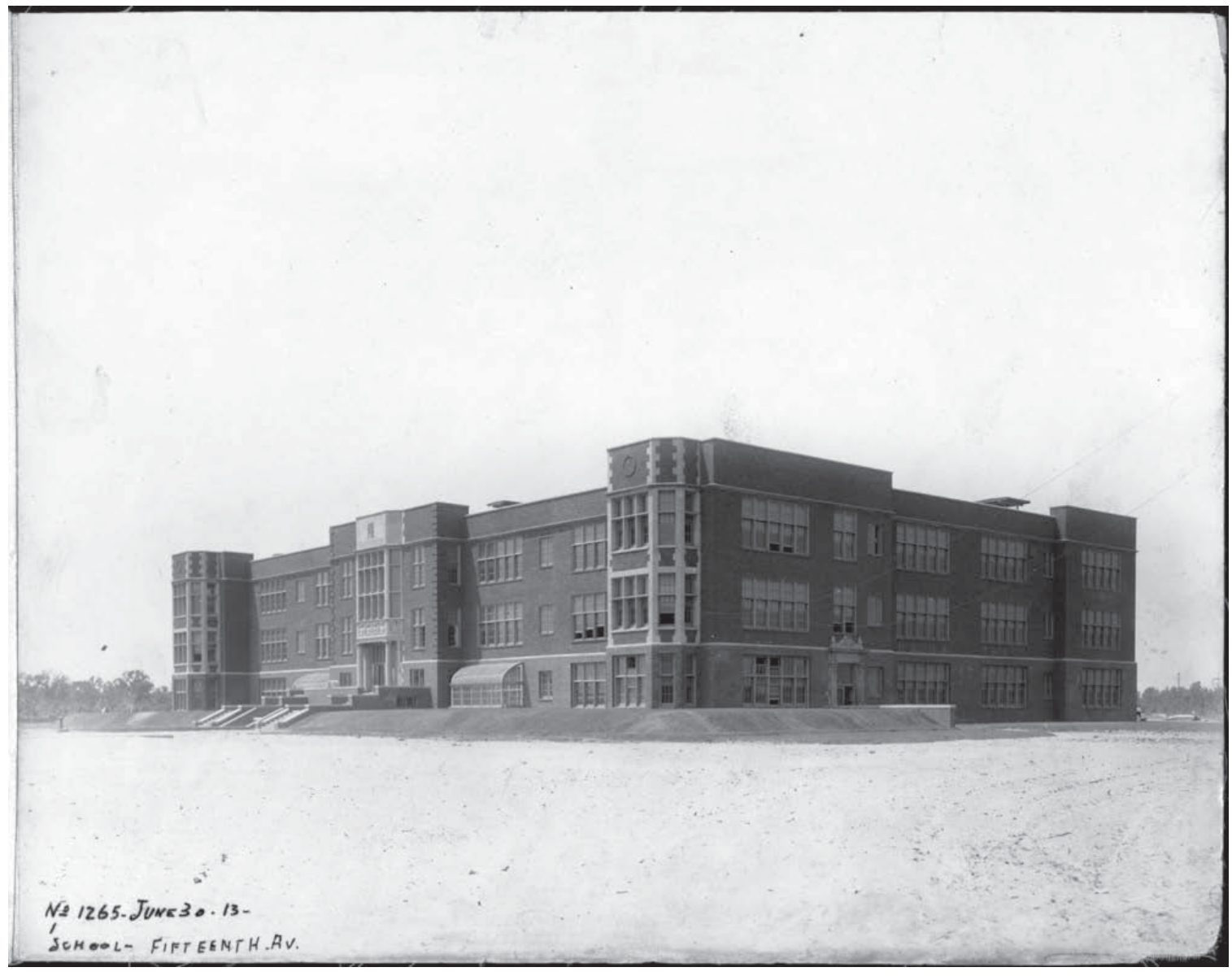

Figure 3.7 Froebel School shortly after construction in 1913. Note lean-to greenhouse adjacent to front entrance. Courtesy of Calumet Regional Archives, Indiana University Northwest. 


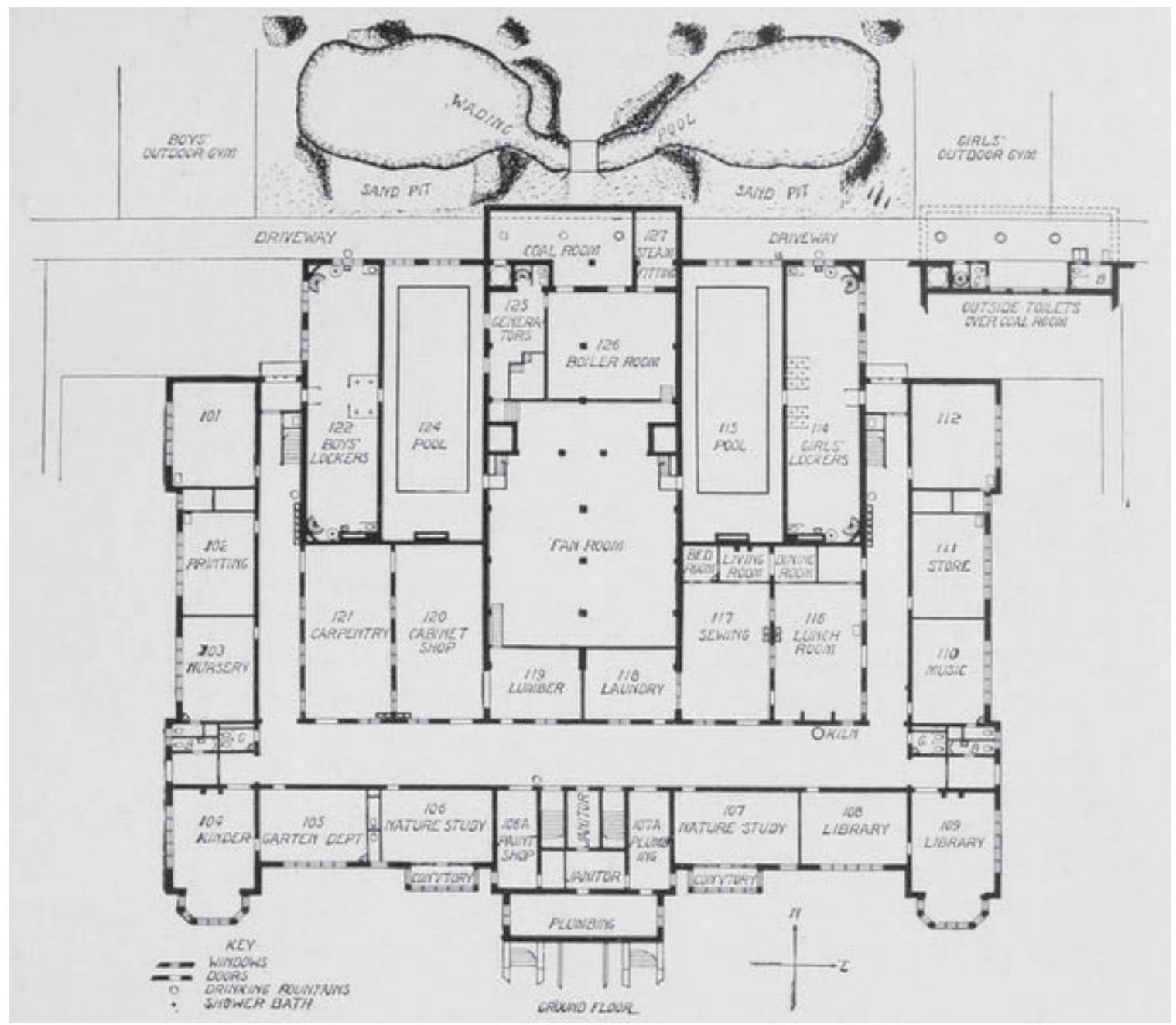

Figure 3.8 The ground floor plan of Froebel School includes the boys' and girls' indoor pools, workshops, laboratories, and part of the playground, ca. 1914. Image reproduced from Burris, The Public School System of Gary, Ind. (1914), 17. 


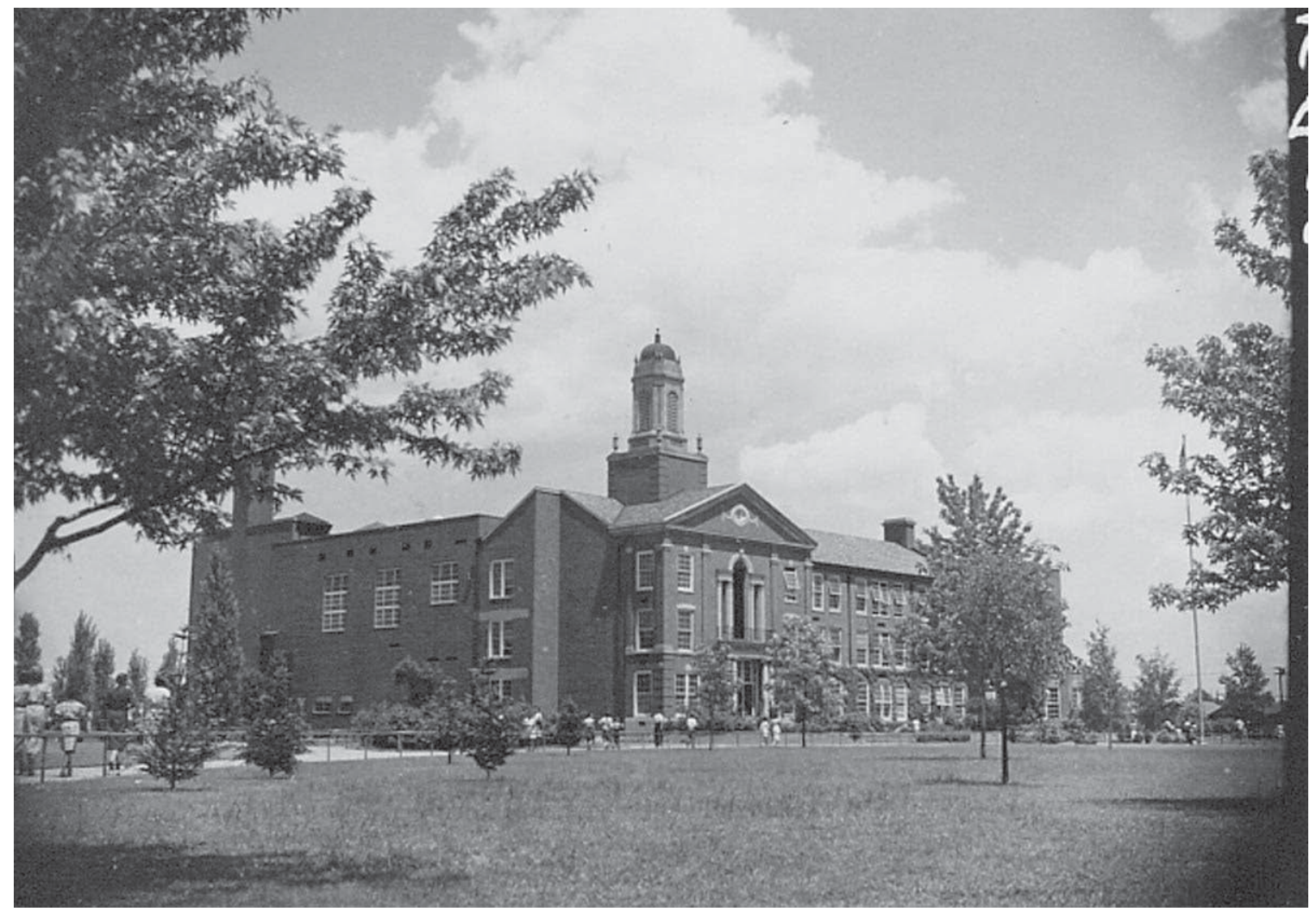

Figure 3.9 Roosevelt School in 1938. It has since expanded multiple times, and exists today as the charter school Theodore Roosevelt College and Career Academy. Courtesy of Calumet Regional Archives, Indiana University Northwest. 


\section{"Make the Steel Corporation a good place for them to work and \\ live. Don't let the families go hungry or cold; give them \\ playgrounds and parks and schools and churches, pure water to drink, every opportunity to keep clean, places of enjoyment, rest, and recreation." 1}

\section{Chapter 4: Welfare Capitalism as Social Capital}

By 1929, 26-year-old Ella Mae Ross had begun her career as a stenographer for attorney William C. Hueston. A single woman, she stayed with her mother, step-father, and maternal grandmother, Betty Bush, at 1340 Carolina Street. To commute to Hueston's office at 1901 Broadway, in the heart of Midtown, Ross would likely have traversed West Fifteenth Avenue on her way to the commercial boulevard. At its intersection with Connecticut Street, she may have had to pass through an interracial crowd of people in need, waiting to obtain charitable services from the recently-opened W.P. Gleason Welfare Center and Clinic. Named for the first superintendent of Gary Works, the center stood as the city's physical manifestation of U.S. Steel's social welfare program. ${ }^{2}$

Celebrated for his apparent interest in the poor living in the mill gate communities, William P. Gleason echoed the industrial welfare refrain adopted by U.S. Steel that it is necessary to "make life more livable for the worker and his wife and children." Arriving in Gary in 1905, he played an essential role in the development of both the plant and city, balancing his mill superintendence with lending "a patient ear to the laments raised by men and their wives over the deplorable living conditions, sand heat, mud, tumbleweeds..."4 Gleason established his eponymous welfare center and clinic in the wake of the 1913 recession, appointing himself president to a staff offering financial, medical, and food assistance to furloughed Gary Works employees. Despite intentions to close at the recession's end, the organization grew and added programs for child welfare, recreation, and classes in English and citizenship. In 1928, the grand threestory brick building on the corner of West Fifteenth Avenue and Connecticut Street became the center's new home. By the following year, over 7,000 citizens-both employees of U.S. Steel and not—had used the services of the center. The company's

\footnotetext{
${ }^{1}$ Elbert H. Gary quoted in David Montgomery, The Fall of the House of Labor: The Workplace, the State and American Labor Activism, 2nd ed. (New York: Cambridge University Press, 1989), 244.

2 "Report for the Year 1929," in Annual Report, W.P. Gleason Welfare Center, Gary, 1929, Illinois Steel Co. Welfare Association. [U.S. Steel Corporation Collection: Box 1, Calumet Regional Archives at Indiana University Northwest]; Gary, Indiana City Directory (Indianapolis: R.L. Polk \& Co., 1929), 500 and 812; "Ella M. Crump [sic]," in Fourteenth Census of the United States (1930), Gary Ward 4, Lake, Indiana, p. 4B, e.d. 29.

${ }^{3}$ Arundel Cotter, United States Steel: A Corporation With a Soul (Garden City, NY: Doubleday, Page \& Company, 1921), 175.

${ }^{4}$ Undated Gleason quote in Lane, City of the Century, 41.
} 
highly-visible interest in the welfare of their industrial community had proven itself a good paternalistic investment. ${ }^{5}$

Though widely considered pioneers in the field of industrial human relations, U.S. Steel was far from the first major corporation to institute social welfare policy. The Progressive Era was borne of largely secular humanitarian awakenings in the American middle-class. Rapid urbanization brought forth myriad social problems previously unseen in this magnitude. Unsanitary living conditions and food processes spread disease in close quarters. Dangerous working conditions injured, maimed, and killed workers of all ages. Modern technologies were being implemented at a fever pitch, changing the way Americans lived and worked, and those who found rapid assimilation difficult suffered. Skyrocketing immigration created both misunderstandings between ethnicities as well as impenetrably insular ethnic enclaves. Attempts to unionize in the workplace often reinforced this "othering" rather than bringing workers together for a unified cause, as eastern European and southern black immigrants were frequently hired as strike breakers. However, heavy-handed anti-union tactics were proving unsustainable solutions to longstanding socioeconomic problems. In order to stabilize their profits, corporations came to believe that they had to stabilize their workforce.

\section{“Good Welfare Work, Like Good Business, Pays"'}

At the turn of the twentieth century, corporations reeling in the wake of violent labor uprisings eagerly searched for ways to avoid such incidents' effect on their productivity, while simultaneously avoiding unionization on their shop floor. Social historians frequently point to the example set by the National Cash Register Company (NCR) of Dayton, Ohio as a watershed in the development of American industrial relations. In 1892, after only eight years in business, the manufacturer was expanding hastily to meet burgeoning demand. Company president John Patterson lamented that while this meant exploding profit margins, it sharply decreased the rapport enjoyed between management and workers in years past. The net result was soldiering, sabotage, and increased turnover. Patterson questioned if he could foster "an ideal class of workers- 'enthusiastic, loyal, and intelligent'."7 To this end, Patterson hired Dayton home missionary Lena Harvey in 1897 to oversee a program of welfare work to recultivate a "family feeling" among his workers. Within three years, NCR rounded out this program with profit-sharing, subsidized housing, a company library, and "NCR House," a workman's clubhouse and model home. This early form of outwardly-democratic industrial pluralism was deemed a success, and used as a prototype for corporatesponsored welfare work nationwide.

\footnotetext{
${ }^{5}$ Report for the Year 1929, [U.S. Steel Corporation Collection: Box 1, Calumet Regional Archives at Indiana University Northwest].

6 "The Company and Its Employes," The Harvester World 3, no. 7 (1912): 3.

${ }^{7}$ Nikki Mandell, The Corporation as Family: The Gendering of Corporate Welfare, 1890-1930 (Chapel Hill, NC: University of North Carolina Press, 2002), 1-3.
} 
However, the NCR model was not seen as the ideal by all manufactory managers. Remaining hostile to the demands of organized labor in the years following the Haymarket Riot of 1886, Cyrus Hall McCormick, Jr. initially looked on the developments of industrial welfare work with both skepticism and curiosity. It was only in 1901, as the McCormick Harvesting Machinery Company added a twine mill to their Chicago factory that he decided to implement elements of such a program. The twine mill, built to accommodate the binding feature of their signature mechanical reapers, was set to add 400 women to their workforce of 5,000 men. The McCormick family, known for their ardent Presbyterianism, sought to protect their moral reputation, as well as that of their female employees. ${ }^{8}$

Concerned about the effect mill work might have on twine-spoolers' health and virtue, McCormick hired Gertrude Beeks, a government reformer with the Civic Federation of Chicago, as the millworkers' "social secretary." Charged with performing general "betterment work," Beeks sought first to streamline the womens' nutrition by eliminating the "strange Lithuanian sausages, slabs of dark Slovak bread, and uncouth Polack pickles emerging every noon from lunch-baskets" and replacing them with hot, high-quality, and thoroughly Americanized meals served on-plant. ${ }^{9}$ When this failed to connect with the women, she introduced a more commodious change-room with multiple mirrors, chairs, and wash basins - again to little avail. Finally, Beeks brought in a piano to go along with the American meals. The spoolers, largely young immigrants with limited English skills, eventually came to enjoy the universally appealing entertainment and nourishment, saving part of their dinner break for a short dance. Finally, Beeks could report to McCormick the increased productivity a balanced meal and brisk exercise created.

After her initial success in the twine mill, Beeks moved on to the rest of Harvester Works' Chicago factory. Over the next 18 months, she oversaw the implementation of plant-wide ventilation and drinking-water systems, regular outings and field days, drama and music programs, and home visits. However, when she could not convince the heads of newly-merged International Harvester to form a separate social welfare department, and to maintain a living wage for all employees, Beeks resigned. In spite of this, the company's dedication to welfare work did not falter in her absence; rather, it grew. The years following saw the introduction of pension and benefit plans, an elaborate on-plant clubhouse, safety program, and Harvester Industrial Council Plan. Although met with resentment from workers who remembered the affair at Haymarket Square, the benefits were deemed successful, and Beeks — as characterized by the Chicago Daily Tribunean "Anti-Strike 'Social Agent'."10

\footnotetext{
${ }^{8}$ Ibid., 43.

${ }^{9}$ These American meals included "hot soups, good stews, baked apples, and well-made gingerbread." Sarah Comstock, "A Woman of Achievement: Miss Gertrude Beeks," The World's Work, August 1913, 444-448.

10 The declarations of complete success - as well as the designations of Beeks - ultimately proved presumptuous, as another large-scale strike occurred at International Harvester in 1904. "Girl an Angel of Peace: McCormick Company Hires Anti-Strike 'Social Agent'," Chicago Daily Tribune, 24 September
} 
This implication that corporate social welfare programs demonstrated the seeming superfluousness of organized labor quickly caught on in Chicago's industrial sector, and beyond. Quaking in the memory of Homestead and Pullman, the adoption of aggressive policies of welfare capitalism in the form of corporate paternalism, the outward appearance of cooperation with the Progressive movement, and reinforcement by the popular press, was deemed to be the right approach to keeping unions out of American manufacturing in the twentieth century.

In his twenty years as William Deering's personal attorney, Elbert H. Gary paid keen attention to the welfare work done by the Deering Harvester Company and its competitor-turned-ally, McCormick Reaper. A staunch advocate of open-shop practices, he had closely followed the aftermaths of both the Haymarket Affair and the Homestead Steel Strike of 1892. The latter, which occurred at a Carnegie mill in Pittsburgh, exposed the effects of technological improvements on the American steel industry and its labor force. The introduction of the open hearth and continuous production systems at Homestead Works deskilled many of the mill's jobs and caused a sharp spike in unskilled labor to accommodate increased production and new operating positions. Disgruntled skilled union tradesmen responded with a lockout strike that was met with violent reprisals from Pinkerton security agents, and later the Pennsylvania State Militia. After several weeks of bloodshed, legal wrangling, and military occupation, the furnaces were re-lit at Homestead Works, tended largely by non-union Eastern European strikebreakers. The summary defeat of union strikers here, and six years prior in Chicago, struck a lasting blow against organized labor in the American steel industry. ${ }^{11}$ It also, however, demonstrated the need for companies to keep their workforce at least reasonably happy to avoid damaging and potentially deadly labor actions like this.

Following the incorporation of U.S. Steel in 1901, the Amalgamated Association of Iron, Steel and Tin Workers (known as "AA", the same union hobbled by the Homestead Strike) became concerned that the formation of a trust of the nation's largest open shop mills could mean their demise. In response, the AA called for a recognition strike that was quickly put down by the foundation of the steel trust. Permanently crippled, the union adopted a nearly submissive position, in hopes that the appearance of cooperation would gain it favor.

Ever the astute businessman, Chairman Gary saw that labor strategy and timing was of the essence. He knew that while public opinion had turned against the critically weakened AA, the nation was eagerly watching the press for any hint that U.S. Steel was an unscrupulous monopoly. In order to proceed with swift, vertically-integrated business with a stable, content workforce, all while maintaining a good public image, Gary forsook the two extremes to which American manufacturers had become polarized: the

1902, 1; Cyrus McCormick, The Century of the Reaper (Boston: Houghton Mifflin Company, 1931), 261266.

${ }^{11}$ David Brody, Steelworkers in America: The Non-Union Era (New York: Harper Torchbooks, 1969); Paul Krause, The Battle for Homestead, 1880-1892: Politics, Culture, and Steel (Pittsburgh: University of Pittsburgh Press, 1992); Edward Slavishak, "Working-Class Muscle: Homestead and Bodily Disorder in the Gilded Age," The Journal of the Gilded Age and Progressive Era 3, no. 04 (2004). 
totalitarian paternalism that had failed Pullman, and the industrial pluralism that he felt gave too much quarter to labor unions. Instead, he sought to establish a unitarist approach to industrial relations within U.S. Steel. This appealing compromise fulfilled the demand for employee loyalty and managerial primacy of paternalism, while maintaining shades of democracy and common purpose for all staff. By standardizing and disseminating best practices and beneficent programs, while leaving their interpretation and implementation up to the trust's individual subsidiaries, this work could be accomplished in a quick and discernible manner. Key to this approach was establishing a comprehensive, diplomatic, and highly-visible corporate social welfare program.

\section{Safety First}

One year after the incorporation of U.S. Steel, Chairman Gary instituted an employee profit sharing plan, selling stock shares to workers below cost on an installment plan. Although not new to corporations engaging in welfare capitalism, the plan was seen as a way to give all employees financial interest in the company, as well as incentive to work hard. While not required to participate, employees were enticed by regular dividends and bonuses paid even to those who had withdrawn from the program. ${ }^{12}$ Gary extolled its virtues, explaining that it created a personal investment in the company by each stock owner. In 1908, he shared a letter from a stockholding laborer with Harper's Weekly that reported supply theft by a supervisor, recommending he "better have this looked into." Gary, using the letter's author as a positive example, declared:

Now the man who wrote that letter was a laborer who, under the profit-sharing plan, had become the owner of a single share of stock. He was interested, when he saw anything going on of detriment to the company, not perhaps, to the same extent that I would have been, but for precisely the same reason. I tell you that man is no anarchist! He is a capitalist-a partner in the Steel Corporation-one of the owners of the whole business. ${ }^{13}$

The fledgling program was by all accounts successful, though it was quickly overshadowed by growing concerns about occupational safety in U.S. Steel's mills, mines, and transportation subsidiaries. In May 1906, as work was underway on the mill and the city at Gary, Indiana, the Chicago Daily Tribune published several articles condemning the secretive nature of industrial accident reporting at nearby South Works. One inflammatory report_-subtitled "Between Railroad Tracks and Great Furnaces It Stands a Terror to the Army of "Hunkies"'-claimed that city officials only became aware of incidents when a "dead wagon" was requested of Chicago Police Department's

\footnotetext{
${ }^{12}$ Gerald G. Eggert, Steelmasters and Labor Reform, 1886-1923 (Pittsburgh: University of Pittsburgh Press, 1981), 41-43.

${ }^{13}$ John Kimberly Mumford, "This Land of Opportunity: "The Watchword of the Hour - Honest Business and Fair Play'," Harper's Weekly, 13 June 1908, 20-23.
} 
$15^{\text {th }}$ Precinct to pick up a body from the high walls surrounding the plant hospital. These scandalous accounts prompted U.S. Steel vice president William B. Dickson to gather data regarding the rate of deaths and disabling injuries at all U.S. Steel facilities nationwide; the results of this research showed 405 fatalities in 1906 alone. True to the trust's unitarism, he suggested that all subsidiaries evaluate their safety systems, and that U.S. Steel consider adopting a general relief policy for injured workers, widows, and families. ${ }^{14}$ Gary Works, therefore, still under construction, would seem to be an ideal opportunity to fix all these problems from the outset.

The tentative plan was seemingly dashed, however, when a detailed reporting of facts and rumors regarding accidents, deaths, and potential cover-ups appeared in the November 1907 edition of popular Everybody's Magazine. Entitled "Making Steel and Killing Men," reporter William Hard declared that of Dickson's 405 death count, 45 occurred at South Works alone. A further 2,000 workers had been "merely burned, crushed, maimed, or disabled," and tales of dead men being buried in piles of molten slag and injured laborers delirious with pain being coerced into signing away rights to compensation lined the extensive report. ${ }^{15}$ Again, in a dual effort to maintain positive public perception of the corporation, as well as cultivate a healthy, productive workforce, emergency measures were taken to stem the unnecessarily dangerous conditions at all U.S. Steel facilities. By April 1908, the Safety Committee was formally established. Two years later, Dickson reported that the organization was staffed by 50 employees with a budget of $\$ 400,000$. Elbert H. Gary proclaimed in the Committee's first annual report that "we will not hesitate to make the necessary appropriations in money to carry into effect every suggestion that seems to us to be practicable for the improvement of the conditions at our mills, so far as the question of taking care of our employees is concerned." 16

From 1910 onward, the annual implementation of safety practices and procedures within all U.S. Steel subsidiaries was documented in a similar annual report. Early years focused on the broad acceptance of employee safety suggestions, system-wide plant inspections, the installation of machine guards and new safety apparatus, and the dissemination of best practices through individual plant safety subcommittees. The tenets of the Voluntary Accident Relief Plan, which offered compensation to employees injured or killed on the job and their dependents, were delineated in 1911, with much emphasis put on the fact that U.S. Steel was not required to provide such benefits; rather, they generously supplied the program out of sympathy for, and solidarity with, their employees. ${ }^{17}$ The outward appearance of the Voluntary Accident Relief Plan was keenly

\footnotetext{
14 "Steel Mill City Locks Out Police," Chicago Daily Tribune, 14 May 1906, 1; Eggert, Steelmasters and Labor Reform, 43-46.

${ }^{15}$ William Hard, "Making Steel and Killing Men," in Injured in the Course of Duty (New York: The Ridgway Company, 1910), 1-28. [reprinted from Everybody's Magazine, Nov. 1907.]

${ }^{16}$ BSSW, "Committee of Safety," Bulletin 1 (1910): 1. In 1912, the Committee of Safety changed its name to the Bureau of Safety, Relief, Sanitation and Welfare. In 1914, the name was permanently changed to the Bureau of Safety, Sanitation and Welfare (BSSW). All future references to this group's Bulletin are the same publication.

${ }^{17}$ BSSW, "Voluntary Accident Relief Program," Bulletin 2 (1911): 33-36.
} 
calculated to prove to employees and company critics, that U.S. Steel was intensely concerned with the wellbeing of their workers and families.

One feature prominently displayed in the first Bulletin was a selection of signs posted throughout South Works warning of different industrial dangers. These included cautions about stepping on cinders resting above boiling water, crossing billet conveyors, and alerting fellow workers when laboring in confined spaces. All signs were written in English, with translations in Czech, Hungarian, Slovenian, and Polish. (Figure 4.1a) While demonstrating the company's recognition of their non-English speaking workers, this attempt at accommodation assumes that all immigrant workers were literate in their own native languages. This apparent presumption suggests that the new signs were another manifestation of U.S. Steel's drive to publicly exhibit their dedication to the wellbeing of their employees. ${ }^{18}$

Soon realizing that their assumption of literacy might have been too optimistic, U.S. Steel introduced the "Universal Danger Sign," a large uniform red circle that the U.S. Steel Safety Committee hoped would be of particular "benefit [to] the foreigner who cannot read." The sign was featured on the cover of the 1912 Bulletin, and appeared prominently in U.S. Steel's first foray into cinematic propaganda. (Figure 4.1b) Commissioned by the Safety Council, in conjunction with the National Association of Manufacturers, the silent film, "An American in the Making," premiered in 1913 to audiences made up of U.S. Steel employees and their families. (Figure 4.2) The story featured Bela, a Hungarian peasant, who is sent passage to join his brother in Gary. The poor young farmer arrives in Gary, "stupid and uneducated," and is hired as a laborer at Gary Works. While touring the mill, Bela is shown the numerous safeguards provided to workers by the corporation, including goggles for chippers, portable derails for work on the mill's rail system, and areas restricted by the Universal Danger Sign. Transferred to U.S. Steel's Lorain Works in Ohio, he is shown making routine use of the mill's sanitary and rest facilities while on shift in the open hearth department. Bela returns to Gary and enrolls in English classes sponsored by Illinois Steel at the Gary Young Men's Christian Association (YMCA). He walks his beautiful young English teacher to her home in the First Subdivision while wearing his company "Boost for Safety" pin in his lapel. On the front porch, Bela proposes marriage, and she accepts. Six years on, Bela's son attends Froebel School and goes tobogganing at the on-plant ball field at American Bridge Works. ${ }^{19}$

The message sent by the film is clear: if immigrants in U.S. Steel company towns learn skills crucial to modern life, and learn to be Americans by making use of the resources offered to them by the corporation, they will then live the American dream of a happy home, work, and family life. As the Safety Bureau became interested in more than the on-the-job safety of their increasingly foreign-born employees, this "happy ending" became the crux of their message. Silent films, interrupted only by occasional English captions, proved to be an ideal mode of communication with their multicultural

${ }^{18}$ BSSW, "A Group of Typical Enameled Steel Warning Signs," Bulletin 1 (1910): 12.

${ }^{19}$ An American In The Making, directed by Edwin Thanhouser (New Rochelle, NY: Thanhouser Film Corporation, 1913), Film. 
workforce. The films provided demonstrations of what both the corporation and the worker wanted, bridged the language barrier, and suggested anti-union class ideals through popular entertainment. Projected onto the Gary Works' movie screen, these ideals fostered loyalty to the company, binding the worker to the desires of U.S. Steel management through good wages, healthy communities, and patriotic ideals.

\section{U.S. Steel Safety, Sanitation, and Welfare}

By the mid-1910s, the objectives of the U.S. Steel Bureau of Safety, Sanitation, and Welfare became clear: Americanization and company loyalty achieved through education, recreation, and health services. The Bureau's former focus on workplace safety and the provision of comfortable living situations scratched the surface of these goals, but aggressive policies of social welfare were required to clearly address them. The strategies for achieving the desired results differed between subsidiaries and locations, but in Gary, a delicate but direct touch was necessary. These sources for stability and standardization started in two places: in the plant, and in the home.

In addition to the city's schools, education was available to Garyites in a number of non-traditional locations. Chief among these was the Gary Young Men's Christian Association (YMCA), built in 1912 on West Fifth Avenue between Adams and Jefferson Streets. (Figure 4.3) In 1909, Chairman Elbert H. Gary pledged \$100,000 toward its construction; upon its completion three years later, he and U.S. Steel provided another $\$ 140,000$ to equip and pay off the facility debt. Conspicuously visible from the mills, the three-story stone structure occupied an entire city block directly across the street from the city's central Carnegie library. ${ }^{20}$ It hosted dormitory rooms, a gymnasium, recreation areas, a large swimming pool, and several classrooms. Charter members of the Gary YMCA board included both Gary Works' Superintendent William P. Gleason and Gary School District Superintendent William A. Wirt, making the organization's leap into mill-specific education a logical one. ${ }^{21}$

The 1914 BSSW Bulletin declared the entire second floor of the Gary YMCA open for "teaching and demonstrating each branch of mill work" as well as a constant offering of English courses for immigrants. The purpose of this partnership with the YMCA was given as:

To increase the efficiency of the workmen by teaching the fundamental and more advanced principles involved in their individual lines of work.

\footnotetext{
${ }^{20}$ Carnegie made a single $\$ 90,000$ grant for two Carnegie Libraries in Gary in 1910 . The Central library opened in 1912, and the Bailey branch library-located at West $15^{\text {th }}$ Avenue and Madison Street in Midtown-in 1918.

${ }^{21}$ Cohen, Children of the Mill, 32; William Frederick Howat, A Standard History of Lake County, Indiana, and the Calumet Region, (Chicago: Lewis Publishing Company, 1915), 413-414; Quillen, "Industrial City: A History of Gary, Indiana to 1929," 225-226.
} 
To increase the earning power of the pupils by guiding them along the paths of quicker and deeper reasoning which leads to positions of gradually increasing responsibility in all departments of the mill.

To promote and develop the happiness of the pupils by opening the door to a more thorough understanding, not only in their daily work in the shops and mills throughout the plant, but in their home life as well. ${ }^{22}$

This trinity of altruistic-sounding reasons for hosting steel milling and English classes at the Gary YMCA exemplifies the corporation's desire for loyal, efficient workers.

In 1907, the Young Men's Christian Association of America established their Immigration Division, headed by Dr. Peter Roberts. The division served as the greatest single Americanizing agency operating in the latter half of the Progressive Era, with classes being taught in every rural, remote hamlet where a home was found for them. To this end, Dr. Roberts gave his name to an intuitive method of English instruction that focused on simple objectives, repetition, and every-day experience of the student. The latter was latched onto by industrialists seeking to Americanize large foreign-born workforces, notably including Henry Ford and Elbert H. Gary. ${ }^{23}$ Adapted for use at YMCAs in U.S. Steel's mill districts, key phrases featured in the 1914 BSSW Bulletin included "I go to the Employment Office," "I must not climb over the machinery," and "Someday I will make castings." These topical phrases illustrate how these early English courses cultivated diligent, safe workers whose loyalty and future aspirations were inextricably tied to the corporation. ${ }^{24}$

Four years later, the BSSW Bulletin indicates that these classes had moved onplant to classrooms, the library, and auditorium of Gary Works' Office Building. Courses in Blast Furnace Practice, Electricity, Rolling Mill Practice, and Mechanical Drawing were accompanied by "a thorough course in English." Instructors were selected from specialists in each department, and often foremen had their supervisees as students. The Bulletin declared this "mutually beneficial" for fostering that desired impression of working for a common cause, which was also achieved by using real-time mill projects and problems as teaching tools for the appropriate curriculum. The wide range of courses was offered free to any U.S. Steel employee, and all workers were encouraged to take as many as possible in order to increase their breadth of steelmaking knowledge.

Additionally, English courses were divided into elementary, intermediate, and advanced sections that incorporated arithmetic, penmanship and composition, as well as "Civics -

\footnotetext{
${ }^{22}$ BSSW, "Illinois Steel Company: Gary Y.M.C.A. - Its Conception, Its Aims and Its Administration," Bulletin 5 (1914): 87.

${ }^{23}$ Gerd Korman, "Americanization at the Factory Gate," Industrial and Labor Relations Review 18 (1965).

${ }^{24}$ Paul McBride, "Peter Roberts and the YMCA Americanization Program 1907-World War I," Pennsylvania History 44, no. 2 (1977): 145-162; Peter Roberts, "The Roberts' Method for Teaching English to Foreigners," in English for Foreigners, ed. Illinois Miners' and Mechanics' Institutes (Urbana, IL: University of Illinois, 1914), 37-48; BSSW, "Lessons for Teaching Foreigners English by the Roberts Method in Use by Y.M.C.A. Teachers in Our Mill Districts," Bulletin 4 (1913): 8-9.
} 
History of our Country." The effort to create loyal, efficient, steelmaking Americans had gained intensity by shifting its venue directly into the students' workplace. ${ }^{25}$

\section{Time Well Spent While Not at Work}

Many recreational options in Gary were located on mill grounds as well. By 1913, tennis courts had been installed adjacent to the general office building at Gary Works, and multi-purpose Gleason Field-complete with shaded grandstand, running track, and baseball diamond - was opened in time for the First Annual Labor Day Track and Field Meet that fall. (Figure 4.4) Sponsored by the Gary Works Athletic Association, the popular event pitted teams from departments around the mill against each other in relays, pole vaulting, horseshoe-pitching, and a "greased pig free-for-all." The event proved extremely popular, and provided bragging rights for both the participants and management, with photos of tugs-of-war and patriotic displays at Gleason Park appearing in corporation newsletters throughout the year. ${ }^{26}$

Other recreations were off-plant, but remained U.S. Steel-owned, such as the American Bridge Company Clubhouse at the subsidiary's Gary plant. Built by 1920, the large three-story brick building served as a reading room, and recreation, lecture, and dance hall for the "Ambridge" employees and their families. (Figure 4.5) Here, a twolane bowling alley, library, and full-court gymnasium with elevated running track occupied much of the community space. The club, open to nominal dues-paying members from the ranks of American Bridge Works employees, was governed by club members while having its building's taxes, heat, and insurance covered by the company. By keeping some manner of financial control over the clubhouse, American Bridge was able to dictate a number of other social characteristics of its operation, notably the club's prohibition on gambling and intoxicating liquors. Nearly all U.S. Steel subsidiaries had such on-plant employee and family clubhouses, including the railroad clubhouse at Kirk Yard in Gary, and the palatial Steel Works Club in Joliet, Illinois. ${ }^{27}$

Similarly, the Good Fellows Club, another company-sponsored, employeemanaged recreational club emerged from the 1913-1914 Recession. Founded out of a sense of managerial noblesse oblige, U.S. Steel mills and mines throughout the country established the clubs to aid furloughed workers with family necessities including clothing and milk for children. In Gary, W.P. Gleason initially headed the Good Fellows Club, sponsoring a massive club Christmas party in 1916. Held at the Broadway Theatre in

\footnotetext{
${ }^{25}$ BSSW "Our Employees' Evening Schools," Bulletin 7 (1918), 102. [Reprinted from Gary Works Circle, October, 1918].

${ }^{26}$ Gary Works Athletic Association, "Sixth Annual Labor Day Industrial Track and Field Meet, 1916," in Program, Sixth Annual Labor Day Industrial Track and Field Meet, 1919, Illinois Steel Company [U.S. Steel Corporation Collection: Box 1, Calumet Regional Archives at Indiana University Northwest]; Broadway Gate, View Looking N.W. Toward Gen. Office Building and Tennis Court and Subway [photo], 1 August 1913 [U.S. Steel Gary Works Photograph Collection, 1906-1971: The IU Digital Library Program, Calumet Regional Archives at Indiana University Northwest].

${ }^{27}$ BSSW, "Clubhouses," Bulletin 8 (1920): 30-31.
} 
Midtown, the event doled out hundreds of Christmas baskets to needy families, as well as presents, games, and miniature American flags to more than 1,500 children of employees. Clearly W.P. Gleason and U.S. Steel saw the importance of reaching out to children of immigrants during difficult times, to reinforce to them and their parents the correlation between gifts of plenty, symbols of America, and the corporation. ${ }^{28}$

\section{Cultivating Healthy Americans}

The practice of Americanization being pressed onto children of immigrants in order to deliver it directly to their parents was a tactic frequently used by U.S. Steel. One way this was accomplished was by appealing to parents' sense of duty to ensure their children's good health. Early on, the corporation employed "visiting nurses" to administer medical care, as well as practical and sanitary housekeeping and child-rearing advice in their rural mining camps. Cosmopolitan company officials impetuously found fault in the seemingly backward nature of life in the remote camps, initially focusing on moral and physical community improvements there. However, increasing employment of immigrants at mills situated in urban centers shifted that focus to the seemingly unsophisticated practices of eastern and southern European immigrants. These differences were made all the more conspicuous by the difficulties experienced by immigrants from rural, agrarian areas when transitioning to life in densely populated American cities.

By 1913, the Good Fellows Club at Chicago's South Works began collecting a suggested donation of fifty cents per month from each member in order to fund their visiting nurse program. With this emergency fund, the visiting nurse could use her discretion to address any member's crisis, including home furnishings, food, or medical care. Visiting nurses also supervised a company-maintained playground near the mill, from which she could keep tabs on the children's health and appearance. According to the 1913 BSSW Bulletin, this allowed her to diagnose and prevent many cases of illness common in urban blocks densely populated with immigrants not familiar with American standards of sanitation. ${ }^{29}$

The non-emergency services of a visiting nurse were offered free to all employees courtesy of U.S. Steel. The goals of this service are listed in the 1918 BSSW Bulletin as:

1. Attending to the sick.

2. Giving instruction in personal and domestic hygiene and in domestic science.

\footnotetext{
${ }^{28}$ Janice Slupski, Jane J. Jacobs, and Laura L. Knott, "Good Fellow Club Youth Camp," in National Register of Historic Places (U.S. Department of Interior, 2012), 12-13; BSSW, "'Good Fellowship Clubs'," Bulletin 7 (1918): 63-64.

${ }^{29}$ BSSW, "Visiting or District Nurses," Bulletin 4 (1913): 53-58.
} 
3. Helping the families to deal with financial, physical, marital and other domestic troubles. ${ }^{30}$

It is important to recognize that while these health services could be used to make sure workers steered clear of vice and improper living, they were in no way forced upon employees and their families. Unlike Ford company towns, where the "Sociological Division" was empowered to visit workers' houses at any time and at their own discretion in order to enforce rules about smoking, drinking, and other deleterious behaviors, BSSW bulletins stressed that the U.S. Steel services were both complimentary and voluntary. ${ }^{31}$ Visiting nurses deployed by the corporation were only allowed into workers' homes when requested by a member of their immediate family. However, while the medical benefits were generally welcome, much of the visiting nurses' repertoire involved heavyhanded domestic Americanization.

Foreign women and children were instructed by the visiting nurses hired by U.S. Steel as to the proper ways to raise children and maintain a household in America by showing them how they had done so previously was incorrect. Entries in BSSW bulletins tacitly advertised this, including photos captioned with messages of children's cuts and scrapes becoming infected due to mothers' "neglect through ignorance" as to the "scientific" manner of care, the proper method (versus the "Old Country" method) of swaddling infants, and babies being "given up for dead" if not for the interference of the visiting nurse. By 1918, correction of these sins against the American way of life was brought out of the home and into U.S. Steel's own front room with the introduction of Practical Housekeeping Centers (PHC).

Frequently held in a company house, a Practical Housekeeping Center served as the local visiting nurses' home and office, an interior decor vignette showing steelworkers' wives how they might pleasingly decorate their own company homes, and a laboratory for classes and activities aimed at further Americanizing employees' wives and children. Women and girls were particularly targeted for these classes, as many popular offerings involved sewing, dressmaking, cooking, etiquette, and infant welfare. Even a course in proper bed-making technique was featured in several BSSW bulletins through $1920 .^{32}$

In Gary, the main subsidiary's Practical Housekeeping Center was housed in the Illinois Steel Company Welfare Center at 1800 Connecticut Avenue in Midtown. (Figures $4.6 \& 4$.7) Located on the opposite corner from St. Hedwig's Roman Catholic Church and School, a Polish congregation, the storefront-turned-PHC was poised to be the center for Americanization of eastern European families. Here, girls and boys enjoyed

\footnotetext{
${ }^{30}$ Later, providing day nurseries to steelworkers' widows who were compelled to work to support their families was added to this list. BSSW, "Visiting Nurses," Bulletin 7 (1918): 32.

${ }^{31}$ Ford Motor Company. Factory Facts From Ford, 1915. [Benson Ford Research Center Collections. Ford Motor Company Non-Serial Publications Collection: Acq. 2009.0.10.2, from the Collections of The Henry Ford], http://collections.thehenryford.org/Collection. aspx?objectKey=361363.

${ }^{32}$ BSSW, "Practical Housekeeping Centers," Bulletin 7 (1918): 34-35; BSSW, "Twenty Practical Housekeeping Centers," Bulletin 8 (1920): 48-51.
} 
separate clubs in addition to classes, where the visiting nurse guided them in the election of club officers, ratifying their own constitution, and conducting meetings according to Robert's Rules of Order. Additionally, clubs for single women employed by the corporation or in domestic work were advertised as a way to get out of the presumed isolation caused by not having a family to look after, and allow them to mingle at the PHC.

The intention of voluntary Americanization through clubs, classes, and recreation activities was quiet, but clear at Gary's Illinois Steel Company Welfare Center. In fact, the 1918 BSSW Bulletin said just as much:

Through the children's clubs and home-making classes these nurses are given opportunities to inculcate American ideals in the minds of the boys and girls, and through them to reach the parents... classes are formed for the foreign-born women, where they are taught the proper care of their children and homes. Here they acquire some familiarity with the language as well as a knowledge of American standards of living. ${ }^{33}$

The development of a sense of American social and domestic customs, as well as contemporary gender roles within the immigrant's new industrialized environment, was seen as key to their indoctrination as good citizens of Gary as an industrial community. At the behest of their employer, Americanization could be made appealing to new, overwhelmed immigrants when wrapped in a cloak of medical care, work and life skills, recreation, and socialization. However, one traditional element of attraction was missing from U.S. Steel's approach: God. That element would be taken up in Gary by organized religion-though eventually, under the increasing influence of U.S. Steel.

\section{The Settlement Movement}

At the time of Gary's founding, the settlement movement was already firmly entrenched in greater Chicago. Progressive social reformer and Illinois native Jane Addams visited one of the world's first settlement houses, London's Toynbee Hall, in 1887. Here the wealthy heiress gained firsthand knowledge of the movement's active brand of social- and class-based reform, in which educated, middle-class volunteers lived and worked amongst the urban poor. Intending to share the knowledge and culture afforded them by fortunate stations in life, Toynbee Hall volunteers offered medical care, education, and childcare to the underprivileged working class of London's East End. Excited by the cross-cultural society formed by breaching the geographic barriers of

${ }^{33}$ BSSW, "Americanization," Bulletin 7 (1918): 96. 
society and economy, Addams brought the settlement movement to Chicago with the 1889 foundation of Hull House on Chicago's Near West Side. ${ }^{34}$

Hull House served the dense, largely Italian and central European neighborhood from a base of Social Christianity. Adherents to the "Social Gospel" were generally progressive Protestants who believed it man's duty to impose the will and love of God "on earth, as it is in Heaven." Making the Lord's Prayer into a social action involved all levels of social justice, including poverty, ethnic tensions, poor living conditions, and labor issues. Within the early settlement movement, however, keeping the underlying Christianity non-sectarian was a must; sensitivity to the varied creeds found in mixed immigrant neighborhoods such as Chicago's Near West Side was essential to maintaining cross-cultural respect. This was key to the settlement movement's ethos: Americanization was offered to the immigrant as a welcoming advantage in their new home, all while celebrating the unique multicultural elements of their "melting pot" constituency. This, combined with the valued Protestant work ethic, probably sounded like the perfect fit for Gary, Indiana, as an industrial community of immigrants. ${ }^{35}$

The settlement movement came to Gary in 1909 along with wealthy sisters Kate and Jane Williams. The year prior, the women visited Gary to see for themselves if there was any truth to rumors of squalid, vice-filled life among the immigrants in The Patch. Finding the sector's rough condition diametrically opposite of the steel trust's carefully planned and maintained First Subdivision, the Williams sisters set to work independent of any corporate support or sense of noblesse oblige. Horrified by what they saw, these staunchly Presbyterian women funded two kindergartens, a sewing school, and Bible courses on the far south side with the support of the First Presbyterian Church of Gary. The following year, the assignment of Rev. B.M. Baligrodski and his sister to the apparent church mission gave the organization more cohesive order. Moved into a frame house at 1525 Washington Street, classes in sewing and domestic science were joined by a library and reading room, English classes, and religious services and education on Sundays. Area civic and business leaders took note, applauding the settlement in the press for its perceived efforts toward Americanizing the neighborhood's immigrants.

With programs focused primarily on helping immigrant women avoid becoming "a stranger in a strange land," the settlement quickly outgrew the house on Washington Street. With a large grant from the Presbyterian Synod of Indiana, a new brick building was constructed one block to the southwest at 1701 Adams Street. (see Fig. 4.7) Complete with dormitory rooms, class and meeting rooms, a nursery, public baths, and a branch library, the newly dubbed "Neighborhood House" truly lived up to its name: the

\footnotetext{
${ }^{34}$ Jane Addams, Twenty Years at Hull House with Autobiographical Notes (New York: The MacMillan Company, 1911); Chris Bilton, "Jane Addams, Pragmatism and Cultural Policy," International Jounal of Cultural Policy 12, no. 2 (2006).

${ }^{35}$ Crocker, Social Work and Social Order, 133-163; James W. Lewis, At Home in the City: The Protestant Experience in Gary, Indiana, 1906-1975 (Knoxville: The University of Tennessee Press, 1992).
} 
large meeting hall within hosted the religious services of ten different churches of six different denominations. ${ }^{36}$ (Figure 4.8 )

This adherence to the multicultural edict of the Social Gospel was tempered by increasing interest in the Americanization capabilities of the popular settlement house. In 1916, the keen attention of U.S. Steel turned to direct involvement in Neighborhood House with the addition of Gary Works Safety Department employee Bernard Coggan to the staff. In charge of leading English and civics courses at the settlement house, decidedly secular U.S. Steel now had a direct link to the religious entity's Americanization program. This influence increased drastically in 1920, which found several mill officials, Gary Commercial Club members, and their wives on the board of Neighborhood House. In the wake of the Steel Strike of 1919, U.S. Steel-eager to demonstrate its involvement in ground-level civic welfare-promised large financial contributions to the settlement. So much so, in fact, that by 1924, the corporation covered one-third of the organization's yearly operating expenses. What had started as an admired private vehicle for Social Presbyterianism and Americanization had become a fashionable, albeit still helpful and faithful, instrument of the mill's desire for good workers and good industrial relations.

\section{Serving a Catholic Majority}

A more direct example of U.S. Steel's patronage of the settlement movement in Gary is the Gary-Alerding Settlement House. This Catholic settlement house, founded in 1923, was established for seemingly pragmatic reasons. Nearly all other church-based settlement work in Gary up to this point had been under the auspices of various Protestant sects. ${ }^{37}$ However, the majority of eastern and southern European emigrants to Gary was Catholic, and adhered to the faith of their homelands in their new home. The underlying current of Protestant evangelism constantly below the surface of cultural, health, and recreational offerings at the city's settlement houses created problems in client recruitment and retention, which hobbled the settlements' potential for fully Americanizing the city's large Catholic and Eastern Orthodox populations. ${ }^{38}$

In 1913, Gary city directories listed seven Catholic churches-four Roman Catholic, two Orthodox, and one Byzantine-as well as two Catholic parochial schools. ${ }^{39}$

\footnotetext{
${ }^{36}$ Federal Writers' Project of Indiana, The Calumet Region Historical Guide: Containing the Early History of the Region as Well as the Contemporary Scene Within the Cities of Gary, Hammond, East Chicago (including Indiana Harbor), and Whiting, ed. Work Projects Administration Writers' Program, (Chicago: Garman Printing Company, 1939), 195-196.

37 These included Presbyterian Neighborhood House, established 1909 and the Methodist Campbell Friendship House, est. 1912. The YWCA-affiliated International Institute, est. 1919 was not directly sectarian, but Christian nonetheless.

${ }^{38}$ Crocker, Social Work and Social Order, 165-182.

${ }^{39}$ Smith's Directory for Gary, Indiana for 1913, vol. 2, 1913, 25-27. At the time, Byzantine Catholicism and Eastern Orthodoxy were categorically combined under the umbrella of Roman Catholicism. In this directory, however, Orthodox churches are listed separately.
} 
The churches' ethnic allegiances reflected the city's European immigrant demography: Romanian, Russian, Polish, Greek, and Slovak. These same ethnicities dominated the labor force employed at U.S. Steel's Gary subsidiaries. Subsequently, forging solid civic connections with their eastern European workers through their religious communities would be invaluable. The intention was to increase the potential for immigrant workers' Americanization through faith-based programs, and the desired result was stronger, more visible industrial relations and civic involvement.

That same year, Gary Works superintendent W.P. Gleason reached out to The Most Reverend Herman J. Alerding, bishop of the Catholic Diocese of Fort Wayne, to inquire about establishing a Catholic welfare organization in Gary. After meeting with Elbert H. Gary in New York to discuss the partnership, Alerding agreed that the cooperation of corporate social welfare and the Catholic faith was necessary to stabilize the rapidly growing ethnic communities, as well as to stem the mutually-dreaded influence of socialism posed by organized labor. Assuring Chairman Gary that "the organization of parishes for these foreigners would ensure peace and contentment for the city for the steel works," Alerding proposed the initial work be done by supporting separate ethnic parishes in the city. Gary agreed. The result was a $\$ 50,000$ grant to be equally divided among five of Gary's Catholic parishes representing the largest ethnic populations: St. Emeric for Hungarians, Sacred Heart of Jesus for Poles, St. Casimiri for Lithuanians, and two separate Holy Trinity parishes for Slovaks and Croatians. All but one were located in the Midtown neighborhood, central to the city's burgeoning immigrant core ${ }^{40}$ U.S. Steel was now financially entrenched in the religious life of their largest labor demographics.

Despite the initial mutual satisfaction of the U.S. Steel-Gary Catholic alliance, the purposeful segregation created by the support of ethnic parishes ran counter to the "melting pot" purposes of Americanization. Preventing multi-ethnic interaction prevented development of English language skills and American social customs, as well as creating a greater potential for the infiltration of socialism, all points of major concern to U.S Steel. Likewise, the Diocese of Fort Wayne grew concerned over the "clannishness" of such ethnic churches, lest they fall from the papal fold. However, both sides recognized that this was a compromise, and a stepping stone toward greater unity in Gary's Catholic populations. "We must deal with them as we find them," wrote Bishop Alerding to Chairman Gary, "Catholic in religion and foreign in their various nationalities." 41

Satisfaction with this status quo arrangement did not endure in the face of continued growth within Gary's ethnic Catholic community. By 1917, the eastern and southern European Catholic population had exploded, but was falling out of the influence of the church due to a feeling that "the Catholic Church had not interested herself in their social and spiritual welfare, sufficiently, to make of them faithful Catholics and useful citizens." ${ }^{42}$ Bishop Alerding now saw the cultural unification of Americanization as the church's best option for engaging the nominally faithful, preventing the "evil" influences

\footnotetext{
${ }^{40}$ Sacred Heart Roman Catholic Church served the Polish community in Tolleston.

${ }^{41}$ Alerding to Gary, 10 March 1913 (quoted in Crocker, Social Work and Social Order, 168.)

${ }^{42}$ Alerding memorandum, 25 May 1917 (quoted in ibid., 170.)
} 
of organized labor and Protestantism, and maintaining good relations with U.S. Steel. Made more urgent by the Steel Strike of 1919, Alerding found a solution in Father John B. de Ville, head of the local Catholic Instructional League that provided the denomination's educational offerings to Gary Public Schools' Released Time program. Alerding tasked de Ville with centralizing the Americanization efforts of Gary's Catholic churches, emphasizing English language instruction, citizenship, and American patriotism. $^{43}$

Himself an Austrian immigrant, Father de Ville had personal experience in the challenges faced by the unassimilated foreigner. While compassionate, and understanding that immigrants held spiritual attachments to their native tongue, he had also recently returned from aiding Belgian refugees displaced during World War I. Advocating for the refugees meant appealing to the public to buy Liberty Bonds, by appealing to wartime nationalistic fervor. De Ville applied this ardor to his new assignment, dubbed the "Gary Americanization and Social Settlement Endeavors," establishing six satellite centersstrategically placed near public schools - in which propagandist films and rallies, as well as English and citizenship classes were offered to Gary's immigrant Catholics. Zealous in his work, de Ville declared it "of the utmost value in counteracting the socialistic and Bolshevistic tendencies of certain elements among the foreigners who constitute the majority of the inhabitants of Gary." 44 His emphasis on cultural homogeneity, combined with strict political conformity, made nationalists nationwide take note.

Wishing to expand the popular diocesan Americanization programs, de Ville and Alerding appealed to Judge Gary for assistance in creating a proper Catholic settlement house. At the time, faltering steel prices tabled the request. However, persistence from the Gary church leaders kept it in the chairman's view. Following a letter in which Bishop Alerding proclaimed, "May [the supported Gary ethnic] parishes have still further reasons to thank God and implore His blessing on the future of the United States Steel Corporation," he was sold. The seemingly solid evidence that U.S. Steel had proven itself a friend of Gary's Catholic populations, and their mutual desire to press onward in Americanizing the city's labor force was made manifest in a \$100,000 check from Judge Gary in early 1921. ${ }^{45}$

The construction of the Catholic settlement house was itself representative of the relationship forged between U.S. Steel and Gary's Catholic leadership. Most obviously, the name ascribed to the house made the partnership crystal clear: Judge Gary-Bishop Alerding Settlement House. The first phase of construction involved building St. Antonio's Chapel, signifying the primacy of Catholic faith in the settlement house's service. Ever the inclusionary cultural pluralist, de Ville wished to provide the chapel for Gary's Italian, Mexican, and Spanish Catholics. Without a parish home, it was thought

43 "Gary Mexicans and 'Christian Americanization': A Study in Cultural Conflict," in Forging a Community: The Latino Experience in Northwest Indiana, 1919-1975, ed. James B. Lane and Edward J. Escobar (Chicago: Cattails Press, 1987), 123-126.

${ }^{44}$ Pamphlet, "The Judge Gary-Bishop Alerding Settlement House," n.d. (quoted in Social Work and Social Order, 173.)

${ }^{45}$ Alerding memorandum, 3 October 1920 (quoted in ibid., 175.) 
the smaller immigrant populations might be more susceptible to social radicals or Protestant evangelism. By giving them a home at St. Antonio's, the seemingly vulnerable growing populations were automatically enfolded in both the Lord's - and Judge Gary's-flock. ${ }^{46}$

Following further donations from U.S. Steel and members of the Gary Commercial Club, the Gary-Alerding Settlement House held its grand opening in December 1923. (Figure 4.9) Located one block west of the "immigrant" Froebel School at West $15^{\text {th }}$ Avenue and Jackson Street, the massive Italianate brick structure dwarfed the city's other settlement houses. (see Fig. 4.7) The extravagant building contained forty rooms, including bowling alleys, a swimming pool, baths, and a central auditorium; the second floor featured a health clinic and dormitory rooms. Father de Ville filled the settlement house with fine furnishing, art, and books with the hope that the items would have a "refining effect" on the working class immigrant children who visited the settlement, instilling in them aspirational class consciousness, and grooming them for further Americanization.

The dedication ceremony held at the settlement house the following May was a further show of aspirational force, featuring a massive parade lead by U.S. Steel officials, ethnic church clubs and bands, and representatives from the Diocese of Fort Wayne, Gary Commercial Club, and area fraternal organizations. From the rooftop, Captain Norton of the Gary Land Company read a speech from Judge Gary to the crowd of 25,000 below that declared "the purpose of this institution [is] to keep these people to their ancient faith, to make Christians as well as Americans out of them. In doing that, this building will be a splendid investment, and it will be repaid an hundred fold.",47

However, the "splendid investment" proved itself to be too late in accomplishing exactly what it set out to do. By the mid-1920s, the southern and eastern European population boom that called for such frantic growth in Gary's Catholic Americanization programs had tapered and stabilized following the immigration-restricting Emergency Quota Act of 1921 and National Origins Act of 1924. Though still serving as a settlement house, the aggressive Americanization plans that gave credence to the Gary-Alerding House were now effectively obsolete. By 1927, the majority of the settlement's patrons were Mexicans, a fact that apparently disgusted an aging Fr. de Ville. Railing against the consequences of this shift in demography, he declared them irredeemable to the Gary Rotary Club later that year: "We have shut out European immigrants and have accepted the uncivilized Mexican in his place. You can Americanize the man from southeastern and southern Europe, but you can't Americanize a Mexican." 48

Father de Ville and Gary's church-based settlement movement may have given up on the "uncivilized Mexican," but curiously not on another growing minority population. Following the Immigration Acts of 1921 and 1924, U.S. Steel solved their dwindling

\footnotetext{
46 Ibid.

47 Thomas Cannon, "Thousands Pay Tribute to de Ville and Donors of Settlement House," Gary Post Tribune, 19 May 1924, 1.

48 "De Ville, O'Hay Rouse Two Gary Audiences by Frank Addresses," ibid., 28 January 1927, 1 and 12.
} 
unskilled labor force problems by looking south. These recruitment efforts were successful in bringing both Mexicans and African-Americans to Gary in large numbers. However, these efforts were strongly weighted toward American blacks, evidenced by their population proportions: in 1920, Mexicans in Gary numbered 166, less than one percent of total population, whereas African-Americans accounted for 9.6 percent, totaling 5,299 citizens. It became clear to U.S. Steel officials and city leaders alike that Gary's black population was rising and stabilizing, as would require similar-albeit separate-welfare services. ${ }^{49}$

\section{Segregated Social Welfare}

Founded in 1920, the John Stewart Settlement House was established to exclusively serve Gary's black population. Though falling under the umbrella of the church-based Settlement Movement, the formation of Stewart House came about quite differently than that of its counterparts. Although U.S. Steel and city officials adhered to voluntary segregationist policies, the Settlement Movement was based upon social inclusion and assimilation. This contradiction reached to the heart of city and steel trust officials' desire to integrate southern blacks into modern industrial society in order to maintain some level of social and labor control: the black population, as the eastern Europeans, was seen as backward and susceptible to the influences of vice, socialism, and disloyalty to their employer. The issue at hand was how to institute social welfare programs in a community that did not require Americanization-as they were already Americans, though "lesser" Americans_-but rather assimilation, and thereby social control. $^{50}$

A solution for this pressing issue was first sought by Gary's white Protestant clergy. Local clerics implored the city's moneyed white public to aid in the provision of segregated social services in imperialistic terms, editorializing that "The white man's burden lies at our doors and not thousands of leagues away across continents and seas," and that Gary's white population must "take up in earnest the uplift of the colored population." 51 One early effort was the establishment of a black-only satellite YMCA, the Hunton Branch, built in the heart of black Midtown at 1716 Washington Street. Blacks were barred from the palatial downtown YMCA, and the Hunton Branch sought to make up for this by offering "a full program... with swimming, volley ball, basketball, Bible study, social games, reading room and fellowship between the hours of 8:30 [a.m.] and 9 p.m." ${ }^{52}$ However, recreation and Bible study was seen as not enough to assimilate an entire community into a "separate, but equal" social harmony.

\footnotetext{
49 "A Study of the Social and Economic Conditions of the Negro Population of Gary, Indiana," (Gary Council of Social Agencies and The National Urban League, 1944).

${ }^{50}$ Crocker, Social Work and Social Order, 183-210.

51 "Uplift of the Colored Race," Gary Daily Tribune, 22 July 1916, 4 and 8. (Quoted in Social Work and Social Order, 187.)

${ }^{52}$ Millender, Yesterday in Gary, 51.
} 
Starting in 1917, U.S. Steel and Gary Land Company sought to exert direct social control over Gary's black community by establishing the Ninth Subdivision. Outwardly, the move showed increasing interest in the home life and conditions of the steel trust's African-American employees locally. However, underneath the benevolent façade ran a current of social control; the efforts were aimed at maintaining unwritten racial real estate covenants, and keeping black employee turnover low. Obviously, their unpleasant working conditions - and those they faced in their Patch homes-often proved unbearable to black workers, stimulating soldiering and high turnover on the job. The establishment of the Ninth Subdivision was intended as a first step in stemming this tide.

Gary Land Company went one step further by trying to entice members of Gary's African-American clergy to move their churches to the Ninth Subdivision. In light of the successes they had experienced with Gary's white religious community, they likely felt that bringing the faith community within the residential community would bring them closer to Jim Crow-style containment while fostering segregated assimilation. Instead, the black religious leaders balked, insisting that the suggestion showed a lack of compassion for the growing minority population. However, these complaints were drowned out by the resolution of thanks enacted by the Calumet Church Federation, a group of Gary's white Protestant clergy who strenuously supported the move. Lead by Reverend William G. Seaman of Gary's First Methodist Episcopal Church, the Federation appealed to U.S. Steel, stating that African-Americans were "not far from the jungle" and "not so much viciously immoral as they are unmoral," which necessitated shepherding them in both civic and religious matters. To accomplish this shepherding, the racist apologist pastor proposed the establishment of a central, white, Protestant-managed religious settlement house for Gary's blacks. To raise the stakes, he also recommended that any corporate support of the city's black churches be withheld until they agreed with Seaman's plans. Satisfied with Seaman's explanation, officials from U.S. Steel, the City of Gary, and the Methodist Conference of Indiana were financially and morally on board. Outnumbered and in need of comprehensive welfare services, the black community slowly turned to make the best out of a less than ideal situation. ${ }^{53}$

In 1919, Elbert H. Gary commented to the president of U.S. Steel subsidiary Tennessee, Coal, Iron and Railroad Company, "It is a great thing to keep in touch with the priests and clergy. The pastors are in contact with the families and the working men themselves." Illinois Steel president Eugene J. Buffington added to this sentiment that good communication was best "especially [with] the colored clergy." 54 In Gary, this was achieved by Reverend Seaman by replacing the head of the all-black Trinity Methodist Episcopal Church with Revered Frank S. Delaney of Chicago. Delaney, an egalitarian African-American pastor willing to overlook his own political leanings for the greater good of his faith community, seemed the perfect fit to open and operate Gary's all black Methodist Episcopal settlement house in cooperation with the steel trust.

\footnotetext{
${ }^{53}$ Crocker, Social Work and Social Order, 189-190.

${ }^{54}$ Business History Society, ed, Addresses and Statements of Elbert H. Gary (1927), 4: 32-33.
} 
With welfare work underway in the community by 1921, designs for the settlement house and new church were contracted to W.W. Cooke, the first AfricanAmerican architect to be licensed by the State of Indiana. Located on a plot at the corner of West $15^{\text {th }}$ Avenue and Massachusetts Street donated by the Gary Land Company, the John Stewart Settlement House opened in November 1925 under the motto of "Christian ideals and racial goodwill." (see Fig. 4.7) The three-story Tudor Revival settlement house hosted a day nursery, infant medical clinic, public dispensary, and rooms for recreation, meetings, dormitories, a legal clinic, and an employment agency. (Figure 4.10) At least initially, the center served as a beacon of racial pride for the black community in Gary: a beautiful building designed by a black architect, named in honor of the first black Methodist missionary, serving God and His people in Gary's burgeoning black community. ${ }^{55}$

It was apparent from early on, however, that Stewart House was less about Christianity and assimilationist social welfare than it was about race-based social control and accomodationist corporate relations. Geographically, this was made plain by its proximity to the Ninth Subdivision, as well as being located just one block from Illinois Steel Company's W.P. Gleason Welfare Center. In 1926, the namesake of the neighboring welfare entity joined the Stewart House board of directors alongside Captain Norton of the Gary Land Company, further infiltrating a corporate presence into the multiracial board. Black members, including Rev. Delaney, architect Cooke, and attorney W.C. Hueston, were repeatedly accused in the Gary Colored American of "selling out their race" to the steel corporation. ${ }^{56}$ This feeling hit a fever pitch in 1928, when U.S. Steel paid off the settlement's $\$ 60,000$ mortgage while ignoring financial requests from other black Gary church groups. While lauded in the press as proof that the steel trust held Gary's black community in high esteem, it was clear that this sealed the settlement's status as one of the corporation's dependents, if not their "pet project."

Historian Ruth Hutchinson Crocker asserts that "Stewart House was an institutional expression of this quasi-feudal relationship between blacks and the steel company." 57 Indeed the organizational structure of Stewart House was set up differently from that of other Gary settlement houses, making the corporate influence stronger than that of the church or the service community. Through heavy-handed support of welfare and relief efforts, U.S. Steel cemented its place as benefactor-if not savior - to the black Stewart House community. In doing so, the company condescendingly "othered" Gary's African-American population with a policy of welfare capitalism far more paternalistic than it had with other civic organizations. Americanization was not necessary in Gary's black community. But, to U.S. Steel, patronization was.

Whatever the core intention behind their differing approaches to social welfare in Gary, U.S. Steel saw their implementation in productive, financial terms. In 1914, Elbert

\footnotetext{
${ }^{55}$ Crocker, Social Work and Social Order, 182-210; Lisa DeNeal, "Historic Site to be Used for Community Garden," Northwest Indiana Post-Tribune, 22 October 2011, 1.

${ }^{56}$ Perplexingly, nearly all of the dissent against the accommodationist policies of Stewart House leadership made a near-complete turnaround by the end of the 1920s.

${ }^{57}$ Crocker, Social Work and Social Order, 195.
} 
H. Gary explained it simply as "The better the physical and moral condition of the employees, the better work they render; and the Corporation, the employer, relies upon the effective services of the employees. So that in dollars and cents it pays us to treat the employees as they deserve." ${ }^{58}$ However, how the corporation determined who of their employees deserved what, depended on their location, ethnicity, and the political climate of the moment. Initially, the welfare services offered directly by U.S. Steel were interracial, perhaps to bring those into the fold that were "othered" by organized labor as strikebreakers.

However, later on these same groups experienced the most heavy-handed Americanization and paternalism through the auspices of religious settlement work. Nonetheless, the steel trust chairman continued, laying out a humanist prerogative for the welfare work done by U.S. Steel:

Through thick and thin, whatever has happened, whatever criticisms have been made from time to time by any one concerning our Corporation, our employees have stood by us and have shown us by their attitude and by their service that they realized our disposition toward them and that they desired to reciprocate. And for these reasons more than anything else, we who are in charge of the affairs of the Corporation are not only obligated but have the very greatest pleasure in doing what we can under all the circumstances to advance the interests of our employees. ${ }^{59}$

By indicating a responsibility to their workers, U.S. Steel crosses a line from a unitary perspective into strict corporate paternalism waged through highly-visible benevolence, the transmission of American standards of living to foreign-born employees, and cradleto-grave campaigns for company loyalty. The essence of this seemingly scattershot implementation of welfare capitalism in Gary, Indiana, was that what served the corporation the best in that moment was what also served the employees-for better or for worse - regardless of race, creed, or ethnicity.

${ }^{58}$ BSSW, "The Story of Steel," Bulletin 6 (1917): 54-55.

${ }^{59}$ Ibid., 55. 


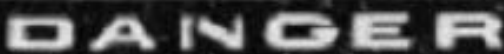

YOU ARC WARNED AG AINST WOAKINO WITHOUT CYC PAOTECTORS OR WIM BATICACD TOOLS OCT PROPEA TOOLS ANO EYE SHIELOS FADH FOAEMAN.

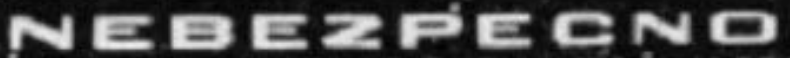

TEBE JE ZAKAZÁNO. PRACOYAT BCZ SKEL NA OĆ ALEQO SE ṠPATNTMA MATROJL. DOSTANNTE DOERE NASTAOJT A SKEL NA OCI OD TORMANA.

VE $=2$ E

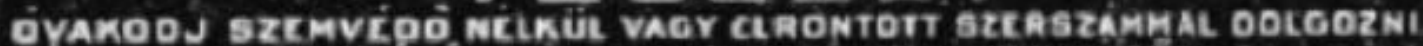

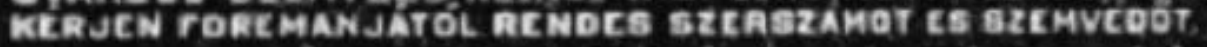

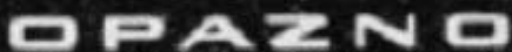

KADA RAOIŚ PAZI DA JE TVOJE GRUOJE BASWIM CIJELOINOSI NAOCALE. SVE CES DOBITI OD FORMANA.

NIEEEZEEE

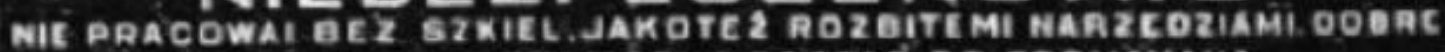
MARZCOZIA I-ZSKLA NA OCZY MOZNA OOSTAC OO TORMAMANA

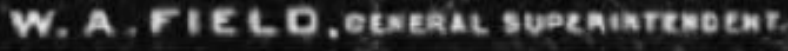

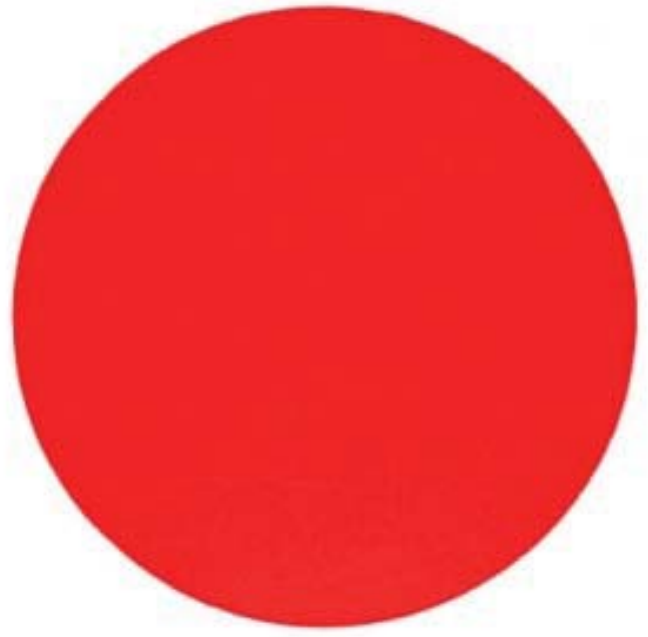

THE UNIVERSAI. DANGER SIGN

Figure 4.1 Two generations of U.S. Steel danger signs: (a) A multilingual safety sign from U.S. Steel South Works in Chicago. Top to bottom, the sign is written in English, Czech, Magyar, Slovenian, and Polish, and endorsed by mill superintendent W.A. Field. This sign appeared in BSSW, "A Group of Typical Enameled Steel Warning Signs," Bulletin no. 1, 1910, p. 11. The languages used on these signs varied regionally based upon the dominant immigrant groups employed locally by U.S. Steel; (b) The "red disk," or Universal Danger Sign implemented in 1912 to communicate warnings to all U.S. Steel employees, regardless of their literacy. The sign appeared on the cover of BSSW, Bulletin no. 3, 1912. 


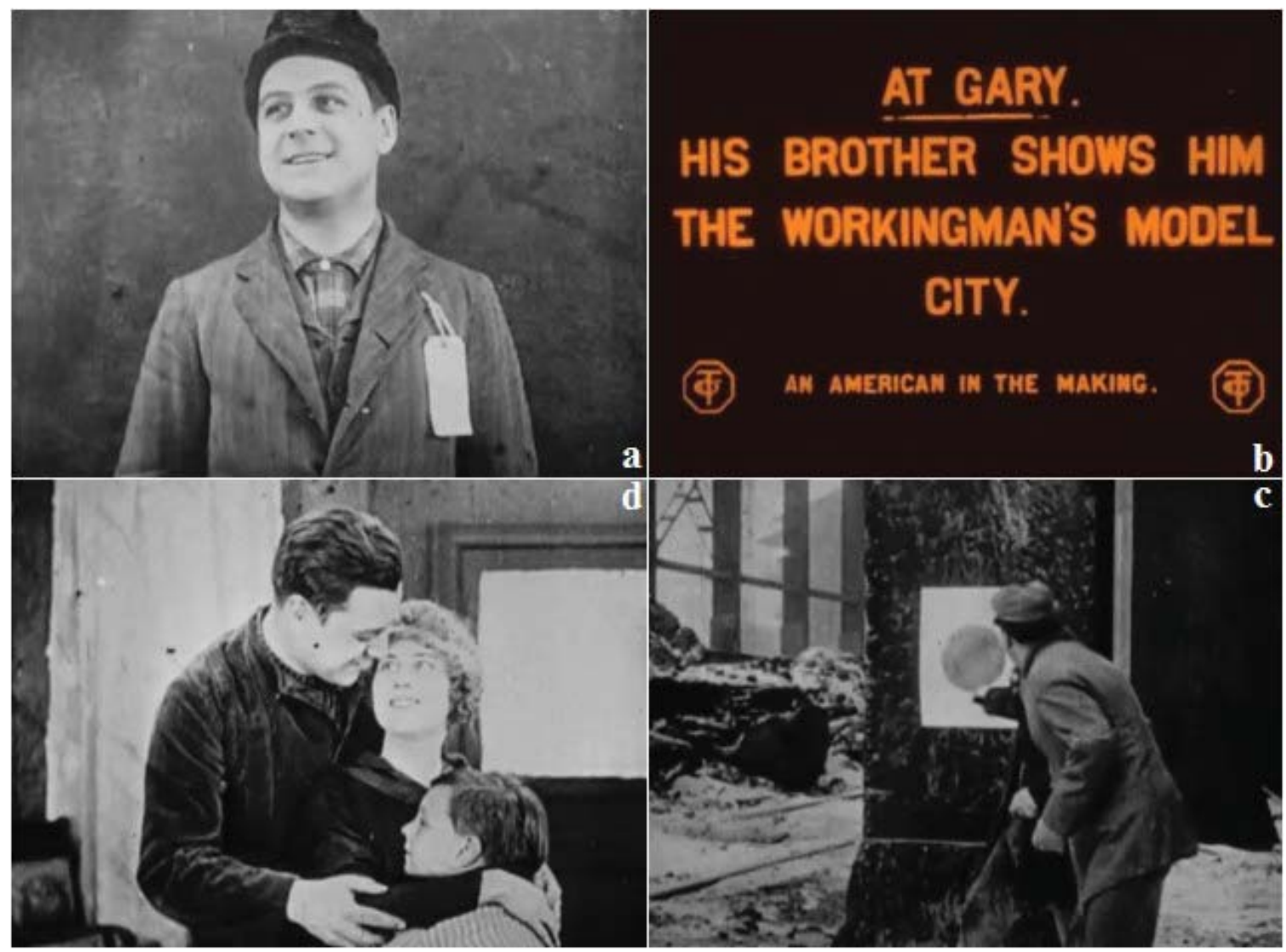

Figure 4.2 Screen captures from the 1913 Edwin Thanhouser film "An American in the Making." Showing clockwise from top left: (a) Hungarian immigrant Bela arrives at Ellis Island; (b) an intertitle introduces Bela to Gary, Indiana; (c) Bela learns of the importance of the Universal Danger Sign at Gary Works; (d) Bela lives happily ever after with his English teacher-turned-wife and young son. 


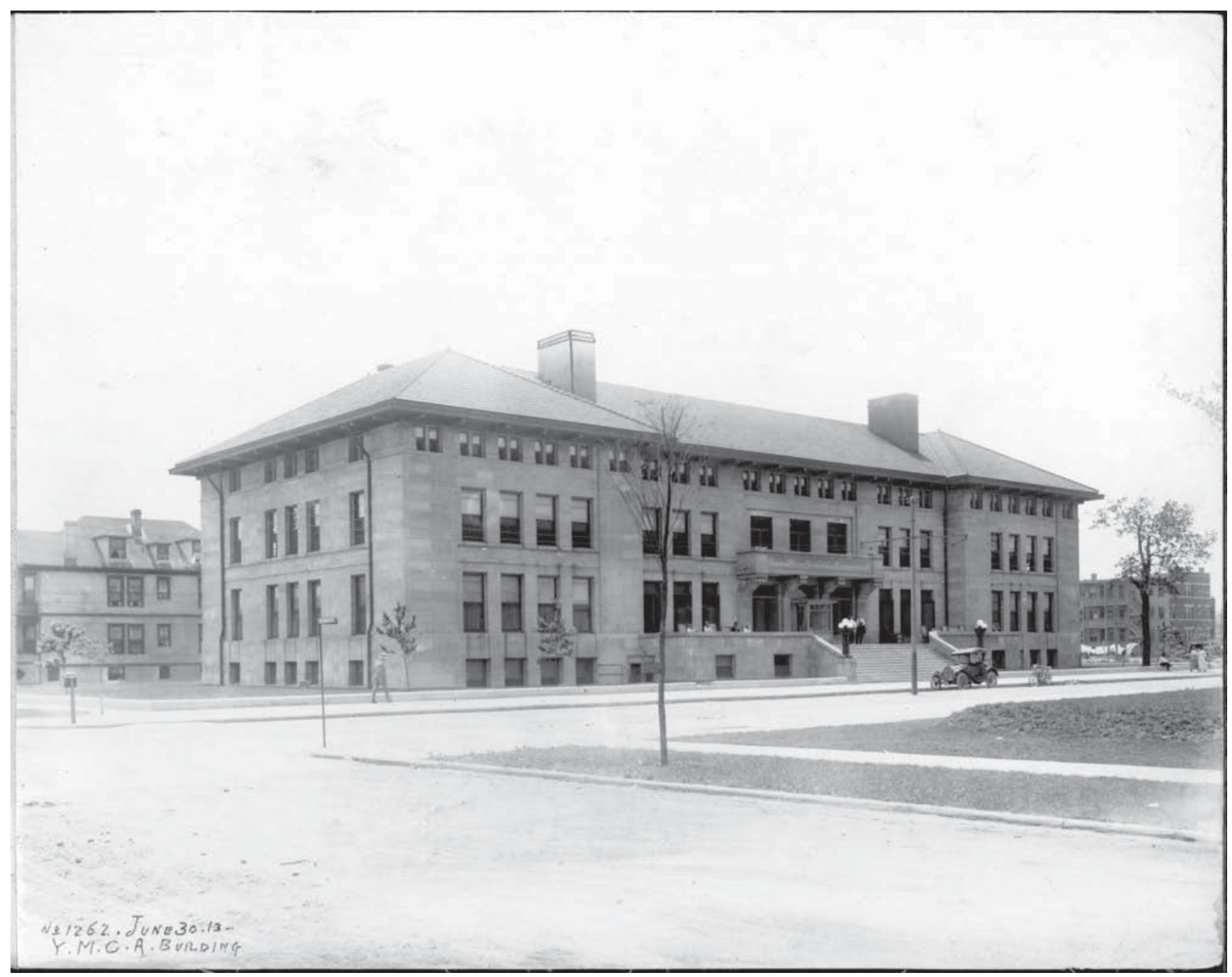

Figure 4.3 The Gary Young Men's Christian Association (YMCA), located on West Fifth Avenue, in 1913. Courtesy of Calumet Regional Archives, Indiana University Northwest. 


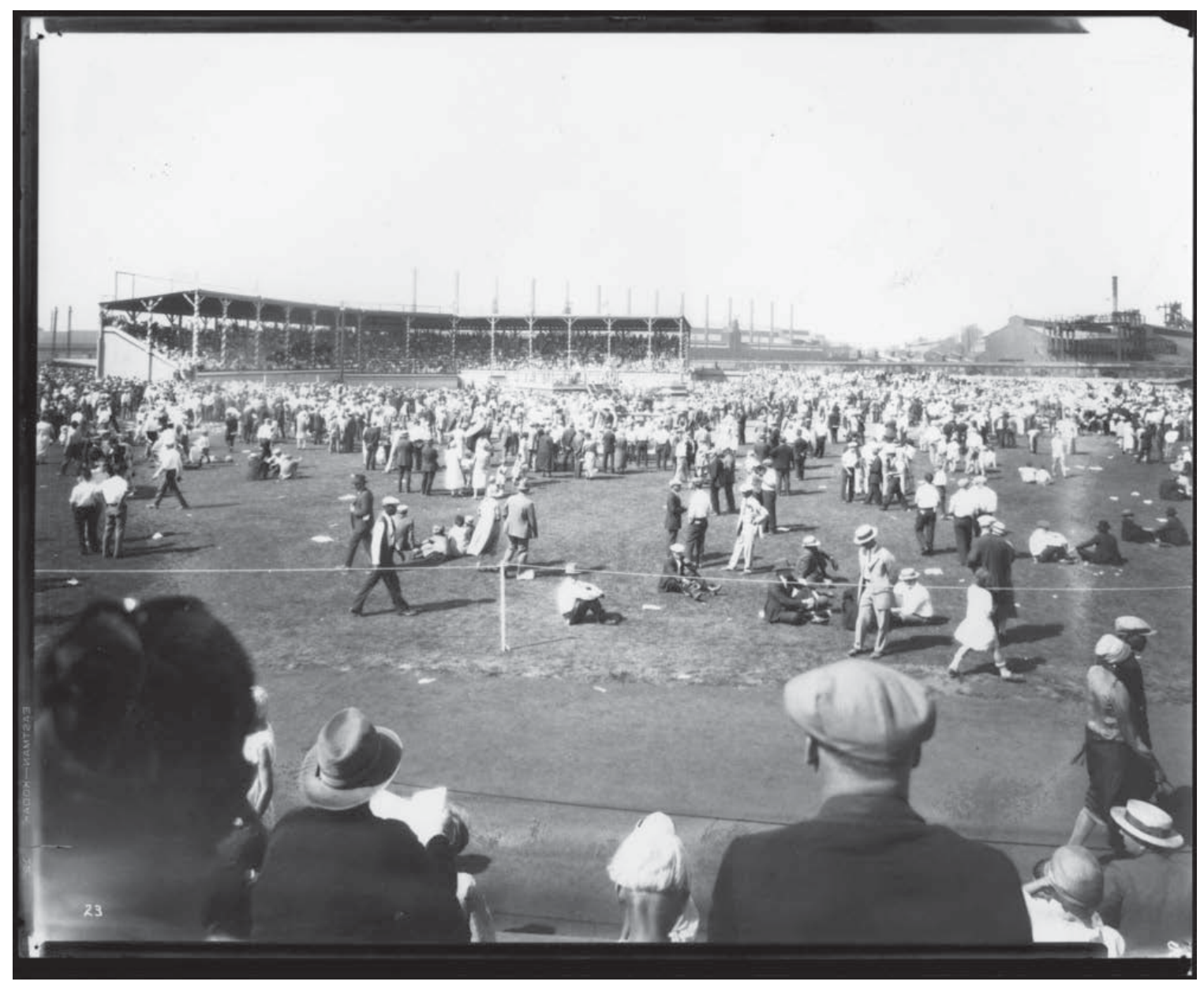

Figure 4.4 A view from one side of the grandstands of the crowds participating in the annual Labor Day Track \& Field Meet at Gleason Field in 1920. Note the recreation area's proximity to the mill in the top right. Courtesy of Calumet Regional Archives, Indiana University Northwest. 


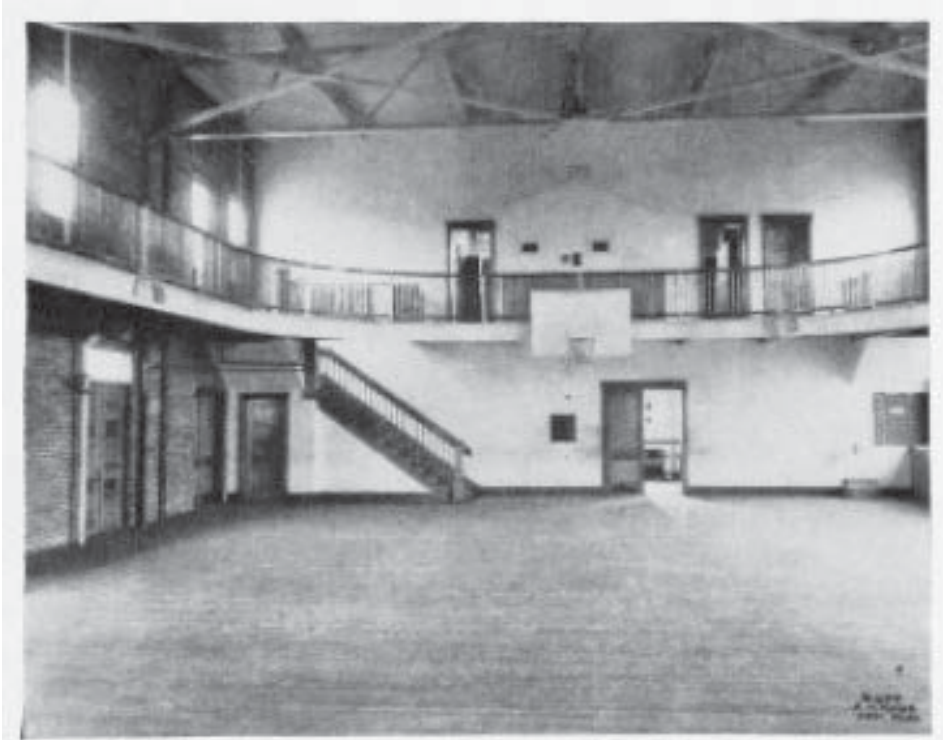

Gymnasium in Gary club house

Figure 4.5 The full-court gymnasium in the American Bridge Works employee club house in Gary. Note the elevated running track. The photo appeared in the BSSW, "Clubhouses," Bulletin no. 8, 1920, p. 31. 


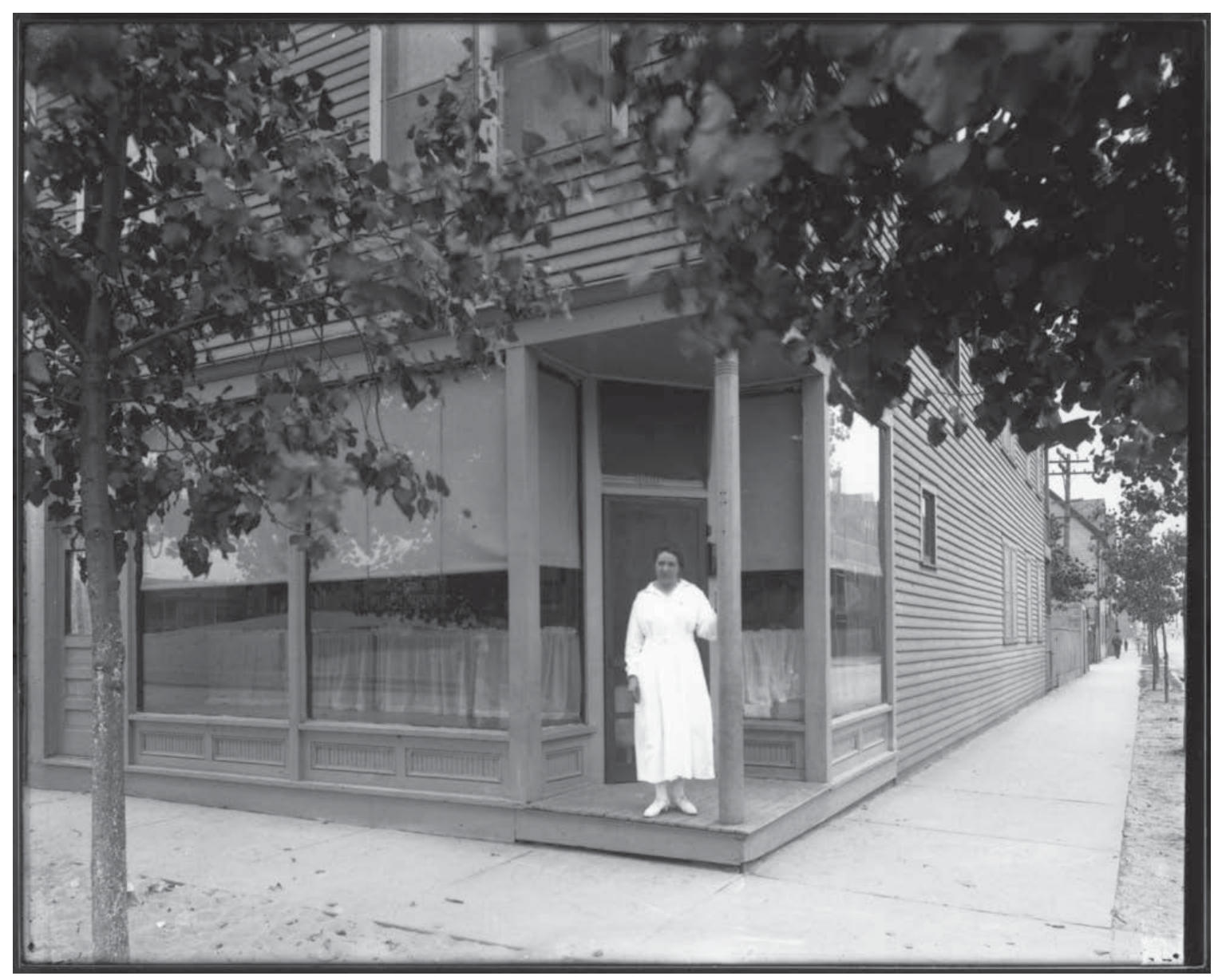

Figure 4.6 The Illinois Steel Company's Welfare Center, located at 1800 Connecticut Street, was staffed by a visiting nurse like the one pictured here in 1921. Courtesy of Calumet Regional Archives, Indiana University Northwest. 

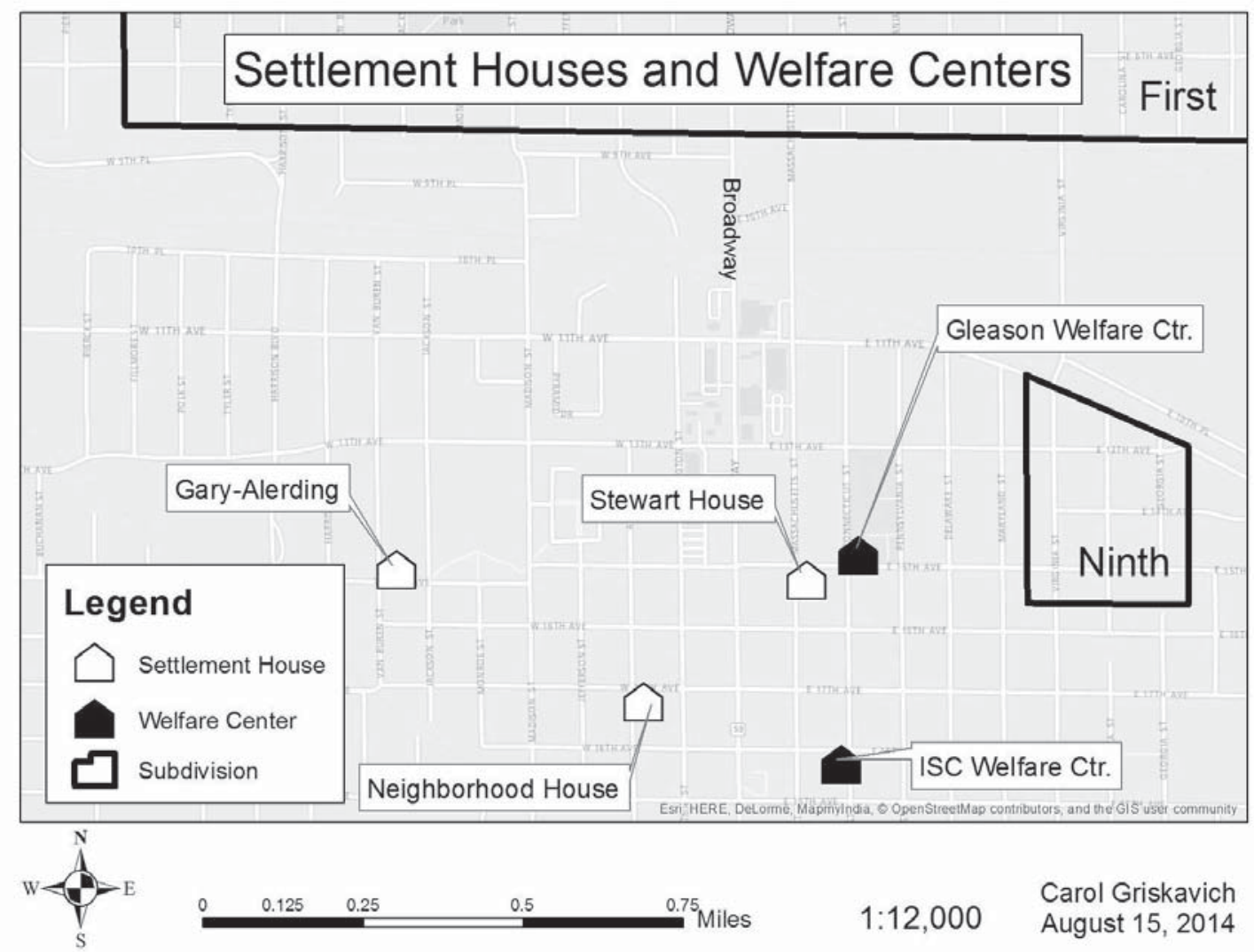

Figure 4.7 The permanent locations of the settlement houses and welfare centers in Gary, Indiana. 


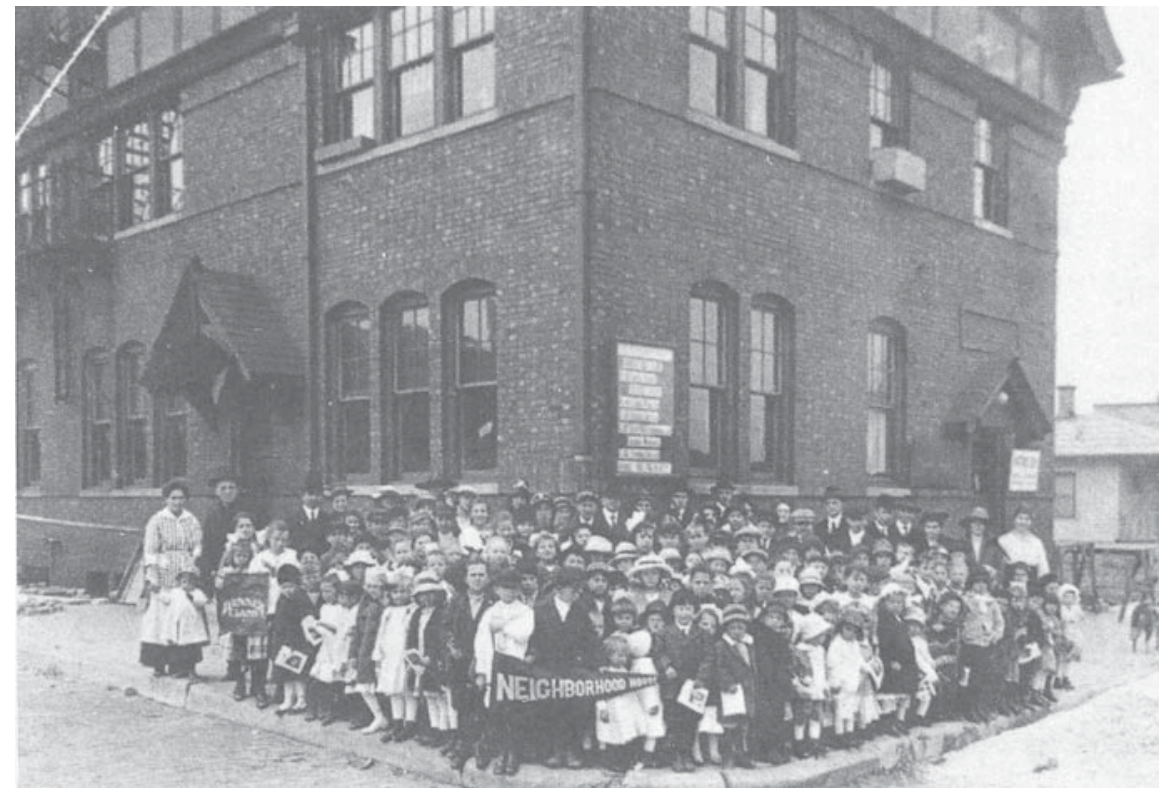

Figure 4.8 Children gathered outside of Neighborhood House in 1919. Courtesy of Calumet Regional Archives, Indiana University Northwest. 


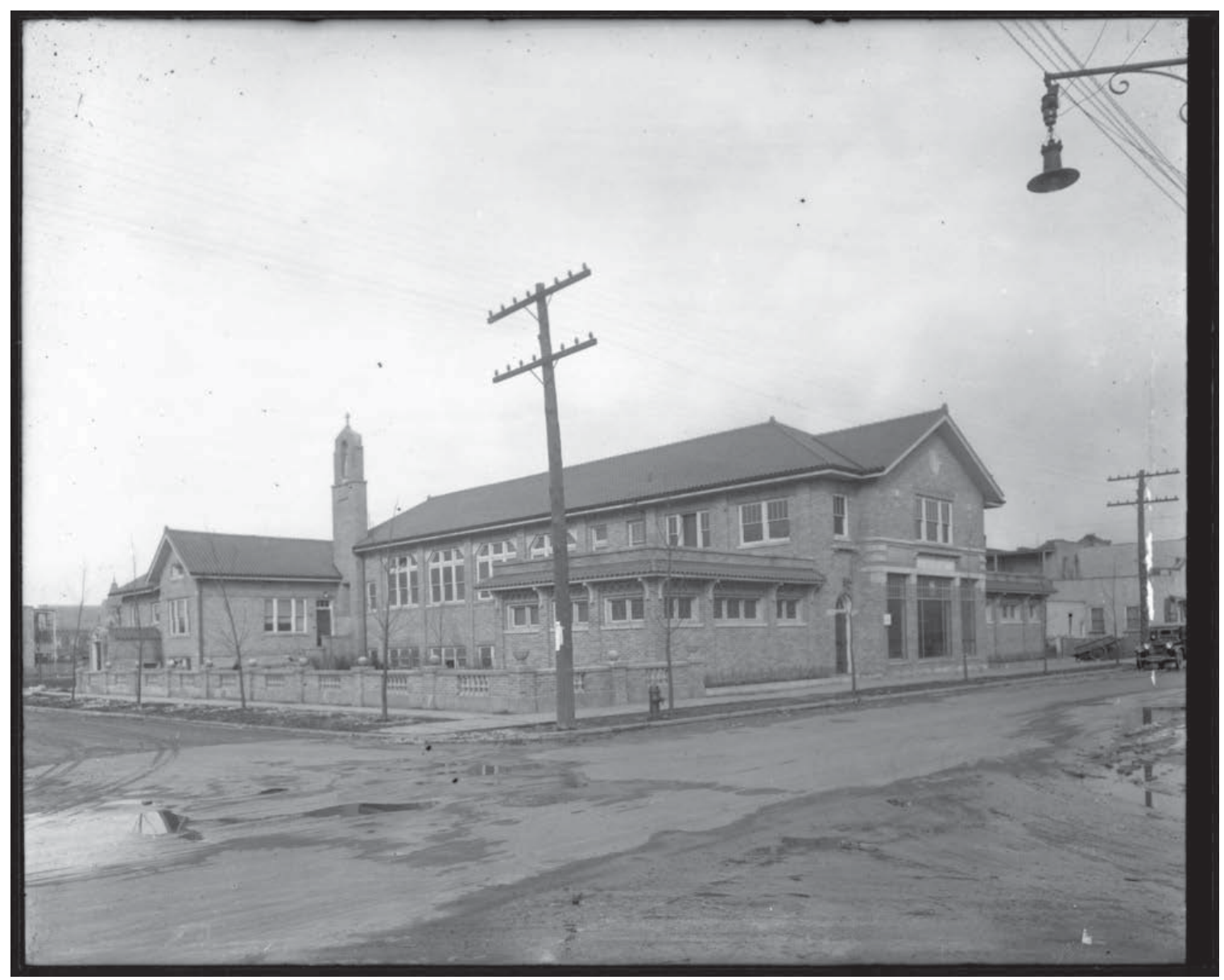

Figure 4.9 The Gary-Alerding Settlement House in 1924. Courtesy of Calumet Regional Archives, Indiana University Northwest. 


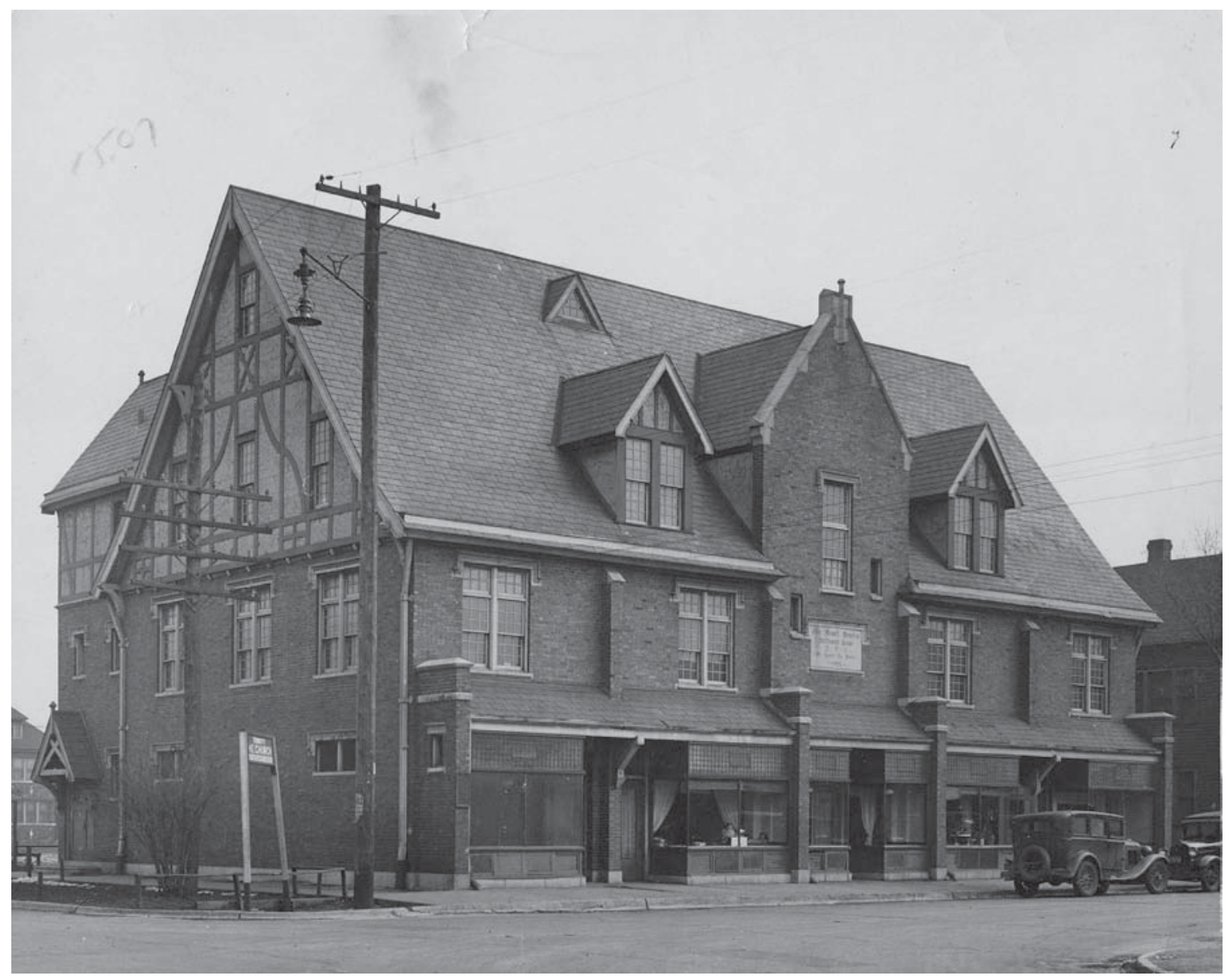

Figure 4.10 The Stewart House in 1936. Courtesy of Calumet Regional Archives, Indiana University Northwest. 


\section{And I saw workmen wearing leather shoes scruffed with fire and cinders, and pitted with little holes from running molten steel, And some had bunches of specialized muscles around their shoulder blades hard as pig iron, muscles of their fore-arms were sheet steel and they looked to me like men who had been somewhere. Gary, Indiana, 1915. ${ }^{1}$}

\section{Chapter 5: Perception, Place, and Pride in a Paternalistic Model City}

Between 1906 and 1930, the city of Gary, Indiana, redefined all previously held meanings of what constituted an industrial community. The concept of an isolated, standardized community controlled by direct edict from autocratic bosses was expressly not used the model for the "Magic City" borne of sand and steel. Rather, heads of the newly-formed United States Steel Corporation looked to the deficiencies of preceding models, and to the tragedies at Pullman and Homestead that both disenfranchised employees and halted trade. From this measured planning, a new model for industrial communities was struck: one that ostensibly prioritized the needs of the mill, while accommodating the needs presented by a rapidly growing and shifting population.

This thesis demonstrates how U.S. Steel changed the historic paradigm of industrial paternalism to create a new model of a company town based on Progressive Era reforms that led to a healthier community and a more loyal workforce. The ever-changing implementation of this policy manifested itself in a reciprocal process that both adapted the function the community, and adapted to community's needs and reactions. The lenses chosen to view this paradigm shift focus on housing and city planning, educational systems, and social welfare practices. Though innumerable other methods could be used, these three shared categorizations that clarify the distinction of the Gary model from previous incarnations of an industrial community. The first of these distinctions is perception, and how it was used to continually reify the reciprocal nature of paternalist relations with the community. Such dialectic was necessary to interact with the physical, built, and cultural landscapes, as well. Finally, both the community and the mill provided themselves, and one another, with identities subject to constant redefinition. A recurrent case throughout these categorizations is the parallel narrative of the African-American experience in Gary. The city's black community continually recontextualized the subpar public perceptions and landscapes assigned to them to embrace sovereign and proud identities that aided the formation of an independent black middle class.

At the turn of the century, perception was not difficult to tap into. Poet Carl Sandburg illustrated the dichotomous nature of power and perception in Gary's early

${ }^{1}$ Sandburg, "The Mayor of Gary," 25. 
years in his poem "The Mayor of Gary," which opens the first and last chapters of this thesis. The popular press was continually fascinated by the "magic city" borne instantly of swamps and sand. This captivation with Gary, combined with fluctuating political tides nationwide, provided U.S. Steel with the advantage of using public perception to fuel their pro-company, union-avoiding operation. Early on, Illinois Steel Company president Eugene J. Buffington publicized the city in an almost dismissive manner, indicating that the new company town was created strictly out of necessity. Any humanitarian touches employed in its organization beyond the basic needs of the mill's workers, he claimed, were borne exclusively out of corporate philanthropy tempered with financial austerity. By publishing these declarations of strict functionality in one of the nation's most popular serials, Harpers Weekly, readers could ascribe their own philosophies and distinctions to the infant city.

At the same time, Buffington's insistence that Gary, Indiana was designed to avoid the missteps made in Pullman set an unattainable precedent of an owner-occupied company town. Certainly it could be argued that Gary Land Company provided differing levels of housing - eventually for rent - out of altruistic necessity. However, by steadily becoming corporate landlords in Gary, U.S. Steel reluctantly crept toward Pullman's paternalist prototype. The trust enjoyed the benefits of the anti-Pullman image they projected, despite of the quiet shift in housing policy. At a time when major corporations remained terrified of the disastrous and vilified legacy of Pullman, the cultivation of a highly-visible positive perception was an invaluable tool of business.

Later, U.S. Steel used public perception as a meter by which they judged the success of their community involvement in Gary. If the public received these efforts well, involvement became increasingly direct and conspicuous. The corporation's involvement with the settlement movement in Gary demonstrates U.S. Steel's adaptation of policy to perception in its exponential investment in church-based settlement houses. Despite the early indifference to the centers aimed at helping children and new immigrants, their importance to the company came from their capacity for Americanization and public health. Once piecemeal grants offered by U.S. Steel were recognized and celebrated in the community, the corporation interpreted this as an endorsement for greater investment. As such, looking good in the eyes of Garyites and stakeholders nationwide quashed any doubt about the culturally calculated move to support the placement of the Gary-Alerding Catholic Settlement House in an eastern European neighborhood. The name alone - a tribute to the chairman of U.S. Steel's Board of Directors and the regional Roman Catholic bishop - is evidence of the distinct adaptation of corporate community involvement based on public reception of paternalistic gestures.

Other changes in corporate policy and relations by U.S. Steel were made in reaction to sharp downturns in public perception. During the infancy of Gary, Indiana, U.S. Steel answered reports of its under-documented on-plant fatality rate in Chicago in a manner befitting a corporation frightened of labor unrest. Rather than denying these reports outright, the steel trust projected proactivity by calling for an internal investigation, and establishing the Bureau of Safety for on-plant concerns. The fledgling bureau, which later came to address workers' off-plant health and welfare as well, 
seemed to satisfy the shaken public. This rapid implementation of reactionary policy dressed as proactive administration demonstrated the level of importance U.S. Steel placed on public perception.

In Gary, reactionary management extended far outside the mill gates, too. As the African-American labor force increased and racial tensions deepened, U.S. Steel responded to claims from the city's white elite of a need for black guidance and separation, as well as the company's own motivations for workforce stabilization. These impressions were built on widely-held racist stereotypes of the era, and initially served to further fracture tenuous relations between Gary's black and white communities. However, agencies such as the Calumet Federation of Churches and events like the Emerson School walk-out of 1927 presented such urgency to resolve "the race issue" that reactionary policymaking was again invoked. Providing African-American children with a new separate school, and their families with a separate settlement house and a neighborhood, was perceived as a great humanitarian success only by those who had insisted on such swift and total regulation, not by the affected population.

Gary's built landscape bears the marks of adaptive and reactionary management as well. No expense was spared in the creation of an ideal and efficient mill at Gary Works. This attitude was also replicated in the city, though not in form, but rather in "industry first" fashion. From its incorporation, invisible boundaries and priorities were set into the city's environment. The mill came first, visually dominating the landscape and effectively cutting off the city from the Lake Michigan shore. The two main streets, Broadway and Fifth Avenue, led to and wrapped around the mill, respectively. Unique dune and swale complexes, formed thousands of years ago, were leveled and covered over in order to create uniformly useable land. The city that occupies this land abuts the mill that dominates its citizen's northerly view, serving as a constant reminder of why Gary was built, and what attracted them to it.

Such symbolic boundaries and arrangements were more open and progressive in Gary's showpiece schools. Just as the adjacency of mill to city fostered a sense of direct purpose for the fledgling city, the implementation of unit schools in Gary reorganized the concepts of labor and space in education. Wirt's plan for the ideal school plant broke away from the traditional school arrangement of pupils learning multiple subjects in the same classroom. Instead, children moved between purpose-built rooms, laboratories, and workshops in order to gain more realistic and focused experience with working environments. The goal of this reorganization was not only to train children for a career, but to maximize the use of school space for children and community members alike. This reconception of learning and labor space in Gary Plan schools represented a changing institutional, industrial, and communal landscape.

The most distinct example of tangible and intangible landscape features in Gary lies in the formation and placement of the Ninth Subdivision. Carved out of an area of The Patch, the black-only neighborhood was removed from Gary Land Company's First Subdivision by one-quarter mile of marshy woods with few connecting streets. Despite being built for a burgeoning African-American population, the newer subdivision was only four percent the size of its stately neighbor. The smaller, less ornate homes built to 
attract Gary's black community to self-segregate stood in stark contrast to the large and varied architecture outside of the subdivision boundaries. Most noticeable of all, however, is the neighborhood's placement south of the Wabash Railroad tracks and wide right-of-way. The symbolism of being pushed to live on the literal "wrong side of the tracks" is not lost on the modern observer, and was likely not lost to observers of any race in 1917.

Finally, the homes, schools, and social welfare institutions of Gary stand as concrete manifestations of a built cultural landscape created by U.S. Steel for its workers. However, these workers did not simply occupy this landscape; rather, they adapted it to their individual and group habitus, and applied their own narrative and meaning to it. As the City of Gary implicitly identifies with U.S. Steel, so too did Garyites grow to identify with their cultural environment.

To many non-landed immigrants from eastern Europe and the rural South, purchasing or renting a Gary home with modern amenities was a watershed moment that represented the milk-and-honey promise that attracted them to this "magic city" in the first place. This would not have been possible without corporate-sponsored development through the Gary Land Company, and later, U.S. Steel's Home Ownership Plan for employees. The opportunity to occupy their own homes with financial backing from their employer allowed Gary steelworkers to explore and define a new marker of individual identity: house pride. This manifested itself in home decoration, as was done by Walter and Maybell Sullivan, or in home additions like that of John and Emma Smith, as well as meticulous painting, maintenance, and landscaping. U.S. Steel encouraged this house pride in its company towns by sponsoring "City Beautiful" contests and offering prizes for the best vegetable and flower gardens through its Bureau of Safety, Sanitation, and Welfare. ${ }^{2}$ Enticing employees to take pride in their homes increased worker morale and stabilized the workforce, thereby reinforcing their identity ascribed to their neighborhood, city, and thereby, the corporation.

Individual pride and self-determination were also indoctrinated within Gary's schools. From early in the pupil's tenure, giving children choices in the content of their education was stressed as a way to instill critical thinking, problem-solving skills, and maturity. Once the student reached the seventh grade, they were allowed to choose their own specialization, whether it be an academic, mechanical, or service track. Additionally, daily Auditorium periods engaged children in oration and demonstrations, building language and presentation skills in native English and non-English speakers alike. The Gary Plan was lauded the world over for bolstering students' self-esteem, analytical skills, and individual and group identity.

Many Garyites past and present would argue that nowhere was this formation of group identity stronger than within the walls of Roosevelt School. Originally a crowded annex, the 1930 opening of the state-of-the-art, black-only school was introduced as a panacea to the explosive racial tensions that culminated in the Emerson walk-out three

${ }^{2}$ BSSW, "American Bridge Company," Bulletin 7 (1918): 48; BSSW, "City Beautiful Contests," Bulletin 5 (1914): 66. 
years earlier. The proposal to accommodate African-American students in a unit school of their own was met with delight from Universal Negro Improvement Association members wishing to further self-segregate, and disdain from a quiet majority.

Faced with severely limited alternatives for higher education, the black Garyites reluctantly came to embrace Roosevelt. While painfully aware of the school's symbolism, many such interpretations were altered by first impressions of the elegant school with its all-black staff who wove lessons of ethnic pride into their rotating platoons and community programs. As more experienced the benefits of an advanced academic and practical curriculum, standout arts and sports programs, and open-use facilities, "The "Velt" came to be viewed as a social hub, and a center of black pride, unity, and identity for nearly four generations of Gary's black community.

Many would argue that the continued paternalistic disposition of seeming "gifts" to Gary's African-American citizenry being met with disdain, reluctance, and finally acceptance is a recurrent theme in this thesis. However, to reduce the thematic role of the black community to merely disenfranchised accommodationists would disregard the external influences that delimited their group and individual agency. Recall that to the Illinois Steel Company, African-Americans were readily available replacements for inaccessible or disagreeable white laborers, tailored for dangerous and undesirable menial labor in the onerous Coke Works and Blast Furnace departments based upon racist beliefs that since "this part...contains a great deal of the hot, dirty, heavy work that Negros were thought to be eminently qualified to perform."3 Deeply-held racist apologist beliefs colored U.S. Steel's patronizing interactions with Gary's black community, as well as those of the city's religious and civic institutions. Industrial paternalism can therefore be seen as both well-meaning and, at the same time, mired in stereotypes. During a time of fervent Americanization, Gary's African-American population was not Americanized, but instead segregated and infantilized by the corporation, the churches, and city leadership.

Despite these challenges, Gary's black community engaged in active resistance and negotiation in order to obtain what they needed - housing, education, welfare programs - and recontextualized what they were provided into their own community assets. Entities such as Roosevelt High School, the Ninth Subdivision, and the Stewart Settlement House, while borne out of segregationist civic policies directly supported by U.S. Steel, became tremendous symbols of black pride through internal practices of appropriation and pride in place. Such adaptation of mainstream ethnic and class consciousness is demonstrated in this thesis by the recurrent John H. Smith family narrative.

The Smith family's example of the establishment of a black middle class in Gary is replete with illustrations of the physical and social trappings thereof: a single-family home with a paid-off mortgage, participation in common school education, connections

\footnotetext{
${ }^{3}$ Richard L. Rowan, "The Negro in the Steel Industry," in Negro Employment in Basic Industry, ed. Herbert R. Northrup (Philadelphia: University of Pennsylvania Press, 1970), 28-29.
} 
to local commerce and the city's elite, vacation property in a black-only northwoods resort town, and involvement in the regional manifestations of black cultural movements. At its core, this example was provided for by U.S. Steel: without his janitor/laborer's paycheck from Gary Works, John H. Smith would not have acquired these trappings of the "American Dream," nor likely a reason to be in Gary. The Smiths serve as a symbol of a discrete, but internally-reified cultural system in Gary: while vocal adherents to Marcus Garvey's black separatist rhetoric, their acceptance - and eventual recontextualization - of civic and corporate offerings to the city's black community represented the overall distinction of a population with its own standards of social capital, cohesion, and civic responsibility. In short, U.S. Steel and Gary, Indiana did not guide the formation of a black middle class. Instead, this thesis demonstrates how the conditions were set for an industrialized black middle class to define, establish, and empower itself within the parameters of a new form of industrial paternalism.

In creating the "magic city," U.S. Steel did not set out to revise the standard for company towns. However, fear of repeating past missteps, Progressive Era expectations, and unbridled production goals inched the corporation closer to heavy-handed labor and community relations. With each new step towards traditional industrial paternalism, U.S. Steel ensured that their actions in Gary appeared diplomatically disseminated, ostensibly unitarist, and above all, highly visible. The formula for success in American business, it would seem, was positive industrial relations compounded with Progressive Era practices and good press. In Gary, this implementation of welfare capitalism created a continuous legacy of real and projected innovation, physical and cultural recontextualization, and group and individual identity. 


\section{List of References}

Abell, Gregg. "Registration Form for Gary-Roosevelt High School." edited by National Register of Historic Places: U.S. Department of Interior, 2010.

Addams, Jane. "A Modern Lear." In Satellite Cities: A Study of Industrial Suburbs, edited by Graham Romeyn Taylor, 60-90. New York: D. Appleton and Company, 1915.

— MacMillan Company, 1911).

Alanen, Arnold R., Morgan Park: Duluth, U.S. Steel, and the Forging of a Company Town. (Minneapolis: University of Minnesota Press, 2007).

Baas, Christopher. "Concrete in the Steel City: Constructing Thomas Edison's House for the Working Man." Indiana Magazine of History 108 (September 2012): 245-273. . "Concrete in the Steel City: The Edison Concept Houses of Gary, Indiana (Multiple Property Documentation Form)." In National Register of Historic Places: U.S. Department of Interior, 2009.

—. "Registration Form for Polk Street Terraces." edited by National Register of Historic Places: U.S. Department of Interior, 2007.

Bennett, James O'Donnell. "Gary School System One of Nation's Finest: Credit Belongs to Supt. William A. Wirt." Chicago Daily Tribune, 9 December 1929, 12.

Bensman, David, and Mark R. Wilson, Encyclopedia of Chicago, s.v. "Iron and Steel," 2005, http://www.encyclopedia.chicagohistory.org/pages/653.html.

Betten, Neil, and Raymond A. Mohl. "The Evolution of Racism in an Industrial City, 1906-1940: A Case Study of Gary, Indiana." The Journal of Negro History 59, no. 1 (1974): 51-64.

Bilton, Chris. "Jane Addams, Pragmatism and Cultural Policy." International Jounal of Cultural Policy 12, no. 2 (2006): 135-150.

Boas, Franz. "Museums of Ethnology and Their Classification (Rebuttal)." Science 9, no. 228 (17 June 1887): 587-589.

Bourne, Randolph Silliman, The Gary Schools. (Boston: Houghton Mifflin, 1916).

Brandes, Stuart D., American Welfare Capitalism: 1880-1940. (Chicago: University of Chicago Press, 1970).

Broadway Gate, View Looking N.W. Toward Gen. Office Building and Tennis Court and Subway [Photo]. 1 August 1913. In U.S. Steel Gary Works Photograph Collection, 1906-1971: The IU Digital Library Program, Calumet Regional Archives at Indiana University Northwest.

Brody, David, Steelworkers in America: The Non-Union Era. (New York: Harper Torchbooks, 1969).

BSSW. "American Bridge Company." Bulletin 7 (December 1918): 48.

_. "Americanization." Bulletin 7 (December 1918): 96.

—. "City Beautiful Contests." Bulletin 5 (December 1914): 66.

—. "Clubhouses." Bulletin 8 (December 1920): 31.

—. "Committee of Safety." Bulletin 1 (1 October 1910).

—. "'Good Fellowship Clubs'." Bulletin 7 (December 1918): 63-64. 
__. "A Group of Typical Enameled Steel Warning Signs." Bulletin 1 (1 October 1910).

. "Home Owning Plan." Bulletin 9 (December 1922).

_. "Home Owning Plan." Bulletin 8 (December 1920).

—_ "House Development at Wilson Station, Pa. For the by-Product Coke Plant." Bulletin 7 (December 1918): 90-94.

_ . "Illinois Steel Company: Gary Y.M.C.A. - Its Conception, Its Aims and Its Administration." Bulletin 5 (December 1914).

— . "Lessons for Teaching Foreigners English by the Roberts Method in Use by Y.M.C.A. Teachers in Our Mill Districts." Bulletin 4 (November 1913).

—. "Our Employees' Evening Schools." Bulletin 7 (December 1918): 102-103.

—_. "Practical Housekeeping Centers." Bulletin 7 (December 1918): 34-35.

—. "The Story of Steel." Bulletin 6 (1917).

—. "Twenty Practical Housekeeping Centers." Bulletin 8 (December 1920): 48-51.

_. "Visiting Nurses." Bulletin 7 (December 1918): 32.

—. "Visiting or District Nurses." Bulletin 4 (November 1913): 53-58.

__. "Voluntary Accident Relief Program." Bulletin 2 (1 July 1911).

Buder, Stanley, Pullman: An Experiment in Industrial Order and Community Planning, 1880-1930. (New York: Oxford University Press, 1967).

Buffington, Eugene J. "Making Cities for Workmen." Harpers Weekly, 8 May 1909, 1517.

Burris, William Paxton, The Public School System of Gary, Ind. vol. 18, (Washington, D.C.: Government Printing Office, 1914).

Business History Society, ed. Addresses and Statements of Elbert H. Gary. Vol. 4, 1927.

Cannon, Thomas. "Thousands Pay Tribute to De Ville and Donors of Settlement House." Gary Post Tribune, 19 May 1924, 1.

"Chicago Coal-Fields: Discovery of Paying Veins near the Calumet." Chicago Daily Tribune, 13 May 1875, 13.

City, Looking N. At Carolina St. From 14th Ave. [Photo]. 3 June 1918. In U.S. Steel Gary Works Photograph Collection, 1906-1971. The IU Digital Library Program, Calumet Regional Archives at Indiana University Northwest.

"Civic Development at Gary." The Iron Age 85 (24 March 1910): 673.

Clark, John T. "The Negro in Steel." Opportunity: Journal of Negro Life, March 1926, 87-88.

"Claud Wilson." In Thirteenth Census of the United States. Hamilton Beat 3, Monroe, Mississippi, p. 11B, e.d. 0064. United States Census Bureau, 1910.

Cohen, Ronald D., Children of the Mill: Schooling and Society in Gary, Indiana, 19061960. (New York: RoutledgeFalmer, 2002).

"The Company and Its Employes." The Harvester World 3, no. 7 (July 1912): 3.

Comstock, Sarah. "A Woman of Achievement: Miss Gertrude Beeks." The World's Work, August 1913, 444-448.

Consumer Price Index Inflation Calculator, s.v. "Consumer Price Index Inflation Calculator," http://data.bls.gov/cgi-bin/cpicalc.pl. 
Cotter, Arundel, United States Steel: A Corporation with a Soul. (Garden City, NY: Doubleday, Page \& Company, 1921).

Crawford, Margaret, Building the Workingman's Paradise: The Design of American Company Towns. (New York: Verso, 1995).

Crocker, Ruth Hutchinson. "Gary Mexicans and 'Christian Americanization': A Study in Cultural Conflict." In Forging a Community: The Latino Experience in Northwest Indiana, 1919-1975, edited by James B. Lane and Edward J. Escobar, 115-134. Chicago: Cattails Press, 1987.

- Social Work and Social Order: The Settlement Movement in Two Industrial Cities, 1889-1930. (Urbana: University of Illinois Press, 1992).

Davis, Horace P. "Company Towns." In Encyclopedia of the Social Sciences. Vol. 4. New York: The Macmillan Co., 1930.

"De Ville, O'hay Rouse Two Gary Audiences by Frank Addresses." Gary Post Tribune, 28 January 1927, 1, 12.

Deed to 1340 Carolina Street for John H. And Emma T. Smith. 26 January 1928. In Abstract of Title, 1340 Carolina Street, (1934-1952), Gary Land Company. U.S. Steel Corporation Collection: Sheet and Tin Mill Series, Box 3, Calumet Regional Archives at Indiana University Northwest.

DeNeal, Lisa. "Historic Site to Be Used for Community Garden." Northwest Indiana Post-Tribune, 22 October 2011, 1.

Dewey, John, and Evelyn Dewey, Schools of Tomorrow. (New York: E.P. Dutton \& Co., Inc., 1915).

Diemer, G. W. "The Platoon School." The Elementary School Journal 25, no. 10 (1925): 734-744.

Drost, Walter H. "Social Efficiency Reexamined: The Dewey-Snedden Controversy." Curriculum Inquiry 7, no. 1 (1977): 19-32.

Edison, Thomas A. 1915. Mold for Concrete Construction. U.S. Patent 1,123,261, filed 29 December 1908, issued 5 January 1915.

- 1917. Process for Constructing Concrete Buildings. U.S. Patent 1,219,272, filed 13 August 1908, issued 3 March 1917.

An American in the Making. Directed by Edwin Thanhouser. New Rochelle, NY: Thanhouser Film Corporation, 1913. Film.

Eggert, Gerald G., Steelmasters and Labor Reform, 1886-1923. (Pittsburgh: University of Pittsburgh Press, 1981).

"Ella M. Crump [Sic]." In Fourteenth Census of the United States. Gary Ward 4, Lake, Indiana, p. 4B, e.d. 29. United States Census Bureau, 1930.

Ely, Richard Theodore. "Pullman: A Social Study." Harper's Magazine 70 (February 1885): 452-466.

"Emma Ross." In Thirteenth Census of the United States. New Madrid Ward 2, New Madrid, Missouri, p. 17B, e.d. 0113. United States Census Bureau, 1910.

"Emma T. Ross." In Thirteenth Census of the United States. New Madrid Ward 2, New Madrid, Missouri, p. 17B, e.d. 0113. United States Census Bureau, 1910.

"Emma T. Smith." In Fifteenth Census of the United States. Gary Ward 4, Lake, Indiana, p. 4B, e.d. 0029. United States Census Bureau, 1930. 
"Features of the City of Gary, Indiana." Iron Trade Review 41, no. 21 (21 November 1907): 837-843.

Federal Writers' Project of Indiana, The Calumet Region Historical Guide: Containing the Early History of the Region as Well as the Contemporary Scene within the Cities of Gary, Hammond, East Chicago (Including Indiana Harbor), and Whiting. ed. Work Projects Administration Writers' Program, (Chicago: Garman Printing Company, 1939).

Ford Motor Company. Factory Facts from Ford, 1915. In Benson Ford Research Center Collections. Ford Motor Company Non-Serial Publications Collection: Acq. 2009.0.10.2, from the Collections of The Henry Ford.

Gary Board of Trustees. "The School Town of Gary." In First Annual Report of the Board of Trustees of the Town of Gary, Ind. for the Year Ending Dec. 31st, 1908, 49-69, 1909.

Gary Land Company's Ninth Subdivision [map]. 20 July 1917. "Lake County, Indiana Plat Books." Crown Point, IN: Lake County Recorder's Office, book 13, p. 15.

Gary Works Athletic Association. Sixth Annual Labor Day Industrial Track and Field Meet, 1916. In Program, Sixth Annual Labor Day Industrial Track and Field Meet, 1919, Illinois Steel Company. U.S. Steel Corporation Collection: Box 1, Calumet Regional Archives at Indiana University Northwest.

Gary, Indiana City Directory. (Indianapolis: R.L. Polk \& Co., 1929).

Gary, Indiana City Directory. (Indianapolis: R.L. Polk \& Co., 1925).

Gary, Indiana City Directory. (Indianapolis: R.L. Polk \& Company, 1918).

"Gary, Indiana: America's Magic City, 1906-1912." 1912.

Gary, Lake County, Indiana [map]. December 1908. "Sanborn Fire Insurance Maps."

New York: Sanborn Map Company, 5.

"Girl an Angel of Peace: Mccormick Company Hires Anti-Strike 'Social Agent'."

Chicago Daily Tribune, 24 September 1902, 1.

Green, Hardy, The Company Town: The Industrial Edens and Satanic Mills That Shaped the American Economy. (Basic Books, 2012).

Greer, Edward, Big Steel: Black Politics and Corporate Power in Gary, Indiana. (New York: New York University Press, 1979).

Grimmer, Anne E. "The Preservation and Repair of Historic Stucco." Preservation Briefs 22 (October 1990 1990): 1-16.

Gutman, Herbert G. "Work, Culture, and Society in Industrializing America, 1815-1919." American Historical Review 78 (June 1973): 531-538.

Haig, Robert Murray. "The Unearned Increment in Gary." Political Science Quarterly 32, no. 1 (1917): 80-94.

Hard, William. "Making Steel and Killing Men." In Injured in the Course of Duty, 1-28. New York: The Ridgway Company, 1910.

Harms, William, and Ida DePencier, Experiencing Education: 100 Years of Learning at the University of Chicago Laboratory Schools. (Chicago, IL: University of Chicago Laboratory Schools, 1996).

Hendrick, Burton J. "Children of the Steel Kings." McClure's Magazine 41, no. 5 (September 1913): 61-69. 
Historic American Building Survey. "Gary Land Company Building." Philadelphia: Department of Interior, n.d.

Hoff, David J. "A Blueprint for Change." Education Week 18, no. 32 (21 April 1999): 37 43.

"A Home Owning Number." Bi-Monthly Bulletin of the American Iron and Steel Institute 5, no. 4 (1917): 103-166.

Hookway, Christopher. "Pragmatism." In The Stanford Encyclopedia of Philosophy. Vol.: 2013.

Howat, William Frederick, A Standard History of Lake County, Indiana, and the Calumet Region. (Chicago: Lewis Publishing Company, 1915).

Hughes, Elizabeth. "Infant Mortality: Results of a Field Study in Gary, Ind., Based on Births in One Year." edited by Children's Bureau U.S. Department of Labor, i122. Washington, D.C.: Government Printing Office, 1923.

Hurley, Andrew, Environmental Inequalities: Class, Race, and Industrial Pollution in Gary, Indiana, 1945-1980. (Chapel Hill, NC: University of North Carolina Press, 1995).

"Industrial Workers' Housing in Wales: Care and Conservation." edited by Cadw: Welsh Historic Monuments. Cardiff: Welsh Assembly Government, 2005.

Insurance Maps of Gary, Indiana [map]. December 1915. "Sanborn Fire Insurance Maps." New York: Sanborn Maps Company, 22.

Insurance Maps of Gary, Indiana [map]. January 1911. "Sanborn Fire Insurance Maps." New York: Sanborn Map Company, 10.

"Iron and Steel: Laying the Corner-Stone of the Joseph H. Brown Works." Chicago Daily Tribune, 6 July 1875, 1.

"John H. Smith." In Fourteenth Census of the United States. Gary Ward 4, Lake, Indiana, p. 29A, e.d. 106. United States Census Bureau, 1920.

"John Wilson." In Sixteenth Census of the United States. Gary Ward 4, Lake, Indiana, p. 1A, e.d. 95-41. United States Census Bureau, 1940.

Jones, Steven Fredrick, Sr. "Woodland Park: Newaygo County's Hidden Black Gem." Michigan History Magazine 94, no. 2 (2010): 40-46.

Jones, William R. "Description of the Plant at Edgar Thomson Steel Works." In Edgar Thomson Works Letterpress Copy Book. Pittsburgh: Edgar Thomson Works, 1877.

"Kannie E. Brundidge." In Fifteenth Census of the United States. Gary Ward 4, Lake, Indiana, p. 5B, e.d. 0029. United States Census Bureau, 1930.

Korman, Gerd. "Americanization at the Factory Gate." Industrial and Labor Relations Review 18 (1965): 396-419.

Krause, Paul, The Battle for Homestead, 1880-1892: Politics, Culture, and Steel. (Pittsburgh: University of Pittsburgh Press, 1992).

Lane, James B., City of the Century: A History of Gary, Indiana. (Bloomington, IN: Indiana University Press, 1978).

Lee, Chang-Shin. "Spin Sisters: Works and Lives of "Lowell Girls" in Early 19th Century America." Journal of British \& American Studies 16 (2007): 189-219. 
Lewis, James W., At Home in the City: The Protestant Experience in Gary, Indiana, 1906-1975. (Knoxville: The University of Tennessee Press, 1992).

Lumpkin, Beatrice, "Always Bring a Crowd!": The Story of Frank Lumpkin, Steelworker. (New York: International Publishers, 1999).

Mandell, Nikki, The Corporation as Family: The Gendering of Corporate Welfare, 18901930. (Chapel Hill, NC: University of North Carolina Press, 2002).

Markie, Peter. "Rationalism Vs. Empiricism." In The Stanford Encyclopedia of Philosophy. Vol.: 2013.

McAlester, Virginia, and Lee McAlester, A Field Guide to American Houses. (New York: Alfred A. Knopf, 2006).

McBride, Paul. "Peter Roberts and the Ymca Americanization Program 1907-World War I." Pennsylvania History 44, no. 2 (April 1977): 145-162.

McCormick, Cyrus, The Century of the Reaper. (Boston: Houghton Mifflin Company, 1931).

Millender, Dharathula H., Gary's Central Business Community. (Chicago: Arcadia Publishing, 2003).

—, Yesterday in Gary: A Brief History of the Negro in Gary. (Gary, IN: D. Millender, 1967).

Mohl, Raymond A. "Alice Barrows: Crusader for the Platoon School, 1920-40." The Elementary School Journal 77, no. 5 (1977): 351-357.

Mohl, Raymond A., and Neil Betten, Steel City: Urban and Ethnic Patterns in Gary, Indiana, 1906-1950. (New York: Holmes \& Meier, 1986).

Montgomery, David, The Fall of the House of Labor: The Workplace, the State and American Labor Activism. 2nd ed., (New York: Cambridge University Press, 1989).

Moore, Will H., "If I Had Known" About Gary in 1909. (Chicago: Barnard \& Miller Print, 1909).

Mosher, Anne E., Capital's Utopia: Vandergrift, Pennsylvania, 1855-1916. (Baltimore: Johns Hopkins University Press, 2004).

Mumford, John Kimberly. "This Land of Opportunity: "The Watchword of the Hour Honest Business and Fair Play"." Harper's Weekly, 13 June 1908, 20-23.

"Need Church, Amusements for Negroes." Gary Daily Tribune, 20 June 1919, 8.

"A New Cement Company." Cement Age 3, no. 1 (June 1906 1906): 365-366.

New Madrid, New Madrid County, Missouri [map]. June 1919. "Sanborn Fire Insurance Maps." New York: Sanborn Map Company, 3.

NYC Planning: Department of City Planning, City of New York. "Nyc Total and Foreign-Born Population 1790-2000." Table, http://www.nyc.gov/htm1/dcp/pdf/census/1790-2000_nyc_total_foreign_birth.pdf.

"Progress Being Made on Concrete Houses for Steel City." Concrete 10, no. 12 (December 1910): 64-65.

"Progress in Concrete Home-Building." Universal Portland Cement Co. Monthly Bulletin 90 (November 1911): 208-211.

Quillen, Isaac James. "Industrial City: A History of Gary, Indiana to 1929." Yale University, 1942. 
"Rabbi Praises Gary School Way of Religious Teaching." Chicago Daily Tribune, 5 March 1916, A3.

Randl, Chad. "The Use of Awnings on Historic Buildings: Repair, Replacement, and New Design." Preservation Briefs 44 (April 2005): 1-16.

Ravitch, Diane, The Great School Wars: A History of the New York City Public Schools. (Baltimore: Johns Hopkins University Press, 2000).

Report for the Year 1929. 1929. In Annual Report, W.P. Gleason Welfare Center, Gary, 1929, Illinois Steel Co. Welfare Association. U.S. Steel Corporation Collection: Box 1, Calumet Regional Archives at Indiana University Northwest.

Richards, Charles Russell, The Gary Public Schools: Industrial Work. (New York: General Education Board, 1918).

Roberts, Peter. "The Roberts' Method for Teaching English to Foreigners." In English for Foreigners, edited by Illinois Miners' and Mechanics' Institutes, 37-48. Urbana, IL: University of Illinois, 1914.

Rowan, Richard L. "The Negro in the Steel Industry." In Negro Employment in Basic Industry, edited by Herbert R. Northrup. Philadelphia: University of Pennsylvania Press, 1970.

"Sam Partridge." In Fourteenth Census of the United States. Gary Ward 2, Lake, Indiana, p. 14B, e.d. 96. United States Census Bureau, 1920.

"Samuel Partridge." In Census of England and Wales, 1881. Swansea, Glamorgan, Wales, p. 6, e.d. 1. 1881.

"Samuel Partridge." In Twelfth Census of the United States. Vandergrift Borough, Westmoreland, Pennsylvania, p. 14B, e.d. 0075. United States Census Bureau, 1900.

"Samuel Partridge." In Thirteenth Census of the United States. Vandergrift Borough Ward 1, Westmoreland, Pennsylvania, p. 5B, e.d. 0209. United States Census Bureau, 1910.

Sandburg, Carl. "The Mayor of Gary." In Smoke and Steel. New York: Harcourt, Brace and Company, 1921.

"School Platoons." Chicago Daily Tribune, 27 June 1924, 8.

Slavishak, Edward. "Working-Class Muscle: Homestead and Bodily Disorder in the Gilded Age." The Journal of the Gilded Age and Progressive Era 3, no. 04 (2004): 339-368.

Slupski, Janice, Jane J. Jacobs, and Laura L. Knott. "Good Fellow Club Youth Camp." In National Register of Historic Places: U.S. Department of Interior, 2012.

Smith's Directory for Gary, Indiana for 1913. vol. 2, (Gary, IN: Edgar Smith, 1913).

STATS Indiana. "Indiana City/Town Census Counts, 1900 to 2010 - Gary City." Table, http://www.stats.indiana.edu/population/PopTotals/historic_counts_cities.asp.

"Steel Mill City Locks out Police." Chicago Daily Tribune, 14 May 1906, 1.

Stephens, Ronald J., Idlewild: The Rise, Decline, and Rebirth of a Unique African American Resort Town. (Ann Arbor, MI: University of Michigan Press, 2013).

Stewart, Doug. "Proud to Be a Mill Girl ". American Heritage 62, no. 1 (2012): 46-55. 
"A Study of the Social and Economic Conditions of the Negro Population of Gary, Indiana." Gary Council of Social Agencies and The National Urban League, 1944.

Taylor, Frederick Winslow, The Principles of Scientific Management. (New York: Harper \& Brothers Publishers, 1911).

Taylor, Graham Romeyn. "Satellite Cities - V. Gary." The Survey 29, no. 22 (1 March 1913): 781-798.

— - Satellite Cities: A Study of Industrial Suburbs. (New York: D. Appleton and Company, 1915).

The Gale Group, International Directory of Company Histories, vol. 50, s.v. "United States Steel Corporation History," 2003, http://www.encyclopedia.com/doc/1G22845400114.html.

Tranfield, Pamela, and Dorothy Nicholson. "Workmen's Houses , Gary, Indiana Photographs, 1916-1917." 2004.

United States Selective Service System. Walter Frederick Sullivan, 1917. In World War I Selective Service System Draft Registration Cards, 1917-1918, Lake, Indiana. Draft Board 1: Precinct 20, Rec. No. 16, National Archives and Records Administration.

United States Strike Commission, Report on the Chicago Strike of June-July, 1894. (U.S. Government Printing Office, 1895).

"Uplift of the Colored Race." Gary Daily Tribune, 22 July 1916, 4, 8.

Volk, Kenneth S. "The Gary Plan and Technology Education: What Might Have Been?". The Journal of Technology Studies 31, no. 1 (2005): 39-48.

Wagner, Paul. Location Survey, 23 August 1952. In Abstract of Title, 1340 Carolina Street, (1934-1952), East Gary, IN. U.S. Steel Corporation Collection: Sheet and Tin Mill, Box 3, Calumet Regional Archives at Indiana University Northwest.

Wallace, James M. "A Gary School Survives: Angelo Patri and Urban Education." History of Education Quarterly 45, no. 1 (2005): 96-111.

Warranty Deed to Woodland Park Lots for Emma T. Smith. 3 December 1928. In Abstract of Title, 1340 Carolina Street, (1934-1952), City of Chicago Trustee. U.S. Steel Corporation Collection: Sheet and Tin Mill, Box 3, Calumet Regional Archives at Indiana University Northwest.

Warren, Kenneth, Big Steel: The First Century of the United States Steel Corporation, 1901-2001. (Pittsburgh: University of Pittsburgh Press, 2001).

Wilson, Mark R., Stephen R. Porter, and Janice L. Reiff, Encyclopedia of Chicago, s.v. "North Chicago Rolling Mill," 2005, http://www.encyclopedia.chicagohistory.org/pages/2793.html.

Wirt, William A. "Industrial Work in Public Schools." The Twenty-third Biennial Report of the State Superintendent of Public Instruction (1906): 377-428. 


\section{Appendix of Permissions}

Note: All figures unaccounted for in this appendix were either created by the author explicitly for use in this thesis, or have been extracted from materials for which the copyright has expired. See figure captions for source citations.

\section{For Figure 1.1}

[Reproduced from http://www.loc.gov/rr/print/res/274_bain.html, visited December 1, 2014.]

George Grantham Bain Collection

Rights and Restrictions Information

Prints and Photographs Division, Library of Congress, Washington, D.C., 20540-4730

There are no known restrictions on the photographs in the George Grantham Bain Collection.

Access: Permitted; subject to P\&P policy on serving originals.

Reproduction (photocopying, hand-held camera copying, photoduplication and other forms of copying allowed by "fair use"): Permitted; subject to P\&P policy on copying. Publication and other forms of distribution: No known restrictions.

Credit Line: Library of Congress, Prints \& Photographs Division, [reproduction number, e.g., LC-B21234]

For more information, please read: Copyright and Other Restrictions: ... Sources for Information

Prepared by: Prints and Photographs Division staff. Last revised: December 20, 2001 


\section{For Figures 2.2, 2.6, 2.9, 3.1, 3.4, 3.6, 3.7, 4.3, 4.4, 4.6, and 4.9}

from: McShane, Stephen G. smcshane@iun.edu

to: Carol Griskavich <cdgriska@mtu.edu>

date: Tue, Apr 15, 2014 at 9:31 AM

subject: RE: US Steel Photo Collections

Hi, Carol, thanks for your note. Things are fine here and I hope you're doing well. It certainly sounds like you're keeping busy!

Re: the US Steel photos, we own the rights to those images, and it's fine if you use some of them in your thesis. We'd like credit, though, something on the order of: Courtesy Calumet Regional Archives, IU Northwest.

Can't believe you're almost finished up with your program! If I hear of anything down here, I'll let you know.

Meanwhile, I hope Spring reaches you at some point up there. We had 2 inches of snow overnight down here! That ain't supposed to happen on Tax Day!!

Take care,

Steve

Stephen G. McShane

Co-director and Archivist/Curator

Calumet Regional Archives

Anderson Library, Indiana University Northwest

3400 Broadway

Gary, IN 46408

Voice: 219-980-6628

Email: smcshane@iun.edu

Website: $\underline{w w w . i u n . e d u / ~ c r a ~}$

From: Carol Griskavich [mailto:cdgriska@mtu.edu]

Sent: Monday, April 14, 2014 9:57 PM

To: McShane, Stephen G.

Subject: US Steel Photo Collections Permissions?

Hi Steve-

I hope April finds you and the Archives well! Things are good, albeit still snowy in the U.P. I had a quick question about using the U.S. Steel Gary Works Photograph Collection digital photos in my Master's thesis. Primarily, what needs to be done? Do I need to provide you with specific photo IDs to be approved, or can there be a "blanket" approval? Mostly I wish to use photos from the Housing category of the collection, though I'm not certain of the exact photos yet. Also, do you need a certain amount of lead time on this? Is there a standard request/permission statement on your end I can help with? ... 


\section{For Figure 2.3}

from: tfox@metalforms.com

to: cdgriska@mtu.edu

date: Thu, Oct 9, 2014 at 1:52 PM

subject: Photo from our website

The email serves as approval to use the photo from our historical timeline on our website, from the 1912 photo referencing the Edison building.

Please let me know if you need anything else.

Regards,

Tim Fox,

President 


\section{For Figures 3.9 and 4.10}

from: McShane, Stephen G. <smcshane@iun.edu>

to: Carol Griskavich <cdgriska@mtu.edu>

date: Fri, Sep 26, 2014 at 3:32 PM

subject: RE: Permission for Specific Photo Use?

Hi, Carol. I've attached two images, one of Roosevelt and one of Stewart House. Will they work for you? If so, consider permission to use them granted.

Steve

Stephen G. McShane

Archivist/Curator

Calumet Regional Archives

Indiana University Northwest

3400 Broadway

Gary, IN 46408

219.980.6628

Fax 219.980.6558

Email: smcshane@iun.edu

CRA Website: www.iun.edu/ cra

From: Carol Griskavich [cdgriska@mtu.edu]

Sent: Friday, September 26, 2014 4:15 PM

To: McShane, Stephen G.

Subject: Re: Permission for Specific Photo Use?

Thanks for your quick response, Steve! I look forward to having my thesis join the archives soon, too.

One additional question, though: turns out that I need historic facade images of Stewart House and Roosevelt HS. I see there are a few in the photograph files (Photographs: Buildings - Box 11 - File 141;

Photographs: Schools - Box 12 - File 119).

Firstly, may I have permission to use the Photograph collections for my thesis? Secondly, what would be the best way for me to get a hold of these images in the next week or so? Do you offer digitization and transfer via email, etc., for specific photos? If not, I'm thinking of coming down next Monday-Tuesday to attend the CHP Local History and Historic Preservation, so if necessary I could swing by campus Monday mid-afternoon or Tuesday morning. I'm in Madison, WI, right now, so the trip wouldn't be quite as long as when I'm up north!

Thanks again for your help! I look forward to your response when you have a moment.

Best,

Carol Griskavich 


\section{For Figure 4.8}

from: McShane, Stephen G. <smcshane @iun.edu>

to: Carol Griskavich <cdgriska@mtu.edu>

date: Fri, Sep 26, 2014 at 6:44 AM

subject: RE: Permission for Specific Photo Use?

$\mathrm{Hi}$, Carol, thanks for your message. Congrats on defending your thesis! When the time comes, we'd be delighted to have a copy in the Archives!

Sure, you have our permission to use those photos, and your credit line is perfect!

I'll have to miss the October CHP conference--I'll be flying out to California to visit my daughter. I'm sure the conference will go really well.

Thanks again for writing, and Congrats again!!

Steve

Stephen G. McShane

Archivist/Curator

Calumet Regional Archives

Indiana University Northwest

3400 Broadway

Gary, IN 46408

219.980.6628

Fax 219.980.6558

Email: smcshane@iun.edu

CRA Website: www.iun.edu/ cra

From: Carol Griskavich [cdgriska@mtu.edu]

Sent: Thursday, September 25, 2014 10:18 PM

To: McShane, Stephen G.

Subject: Permission for Specific Photo Use?

Hi Steve-

I hope the new semester finds you and the archives well! Things are chugging along here - I successfully defended my thesis From Mill Gates to Magic City: U.S. Steel and Welfare Capitalism in Gary, Indiana, 1906-1930, and I'm onto the final revisions now. I have a quick question: I've previously gotten your permission to use images from the Digital Archives in my thesis, but I was wondering if you'd be so kind as to extend that to images from the U.S. Steel Collection and Neighborhood House Collection? Specifically, I'm referring to an exterior shot of Neighborhood House with children holding a banner bearing its name ... 